Portland State University

PDXScholar

\title{
The Effects of Climate Change and Urbanization on the Runoff of the Rock Creek Basin
}

Jon J. Franczyk

Portland State University

Follow this and additional works at: https://pdxscholar.library.pdx.edu/open_access_etds

Part of the Nature and Society Relations Commons, and the Physical and Environmental Geography Commons

Let us know how access to this document benefits you.

\section{Recommended Citation}

Franczyk, Jon J., "The Effects of Climate Change and Urbanization on the Runoff of the Rock Creek Basin" (2008). Dissertations and Theses. Paper 2237.

https://doi.org/10.15760/etd.2234

This Thesis is brought to you for free and open access. It has been accepted for inclusion in Dissertations and Theses by an authorized administrator of PDXScholar. Please contact us if we can make this document more accessible: pdxscholar@pdx.edu. 


\section{THESIS APPROVAL}

The abstract and thesis of Jon J. Franczyk for the Master of Science in Geography were presented March 4, 2008 and accepted by the thesis committee and the department.

COMMITTEE APPROVALS:

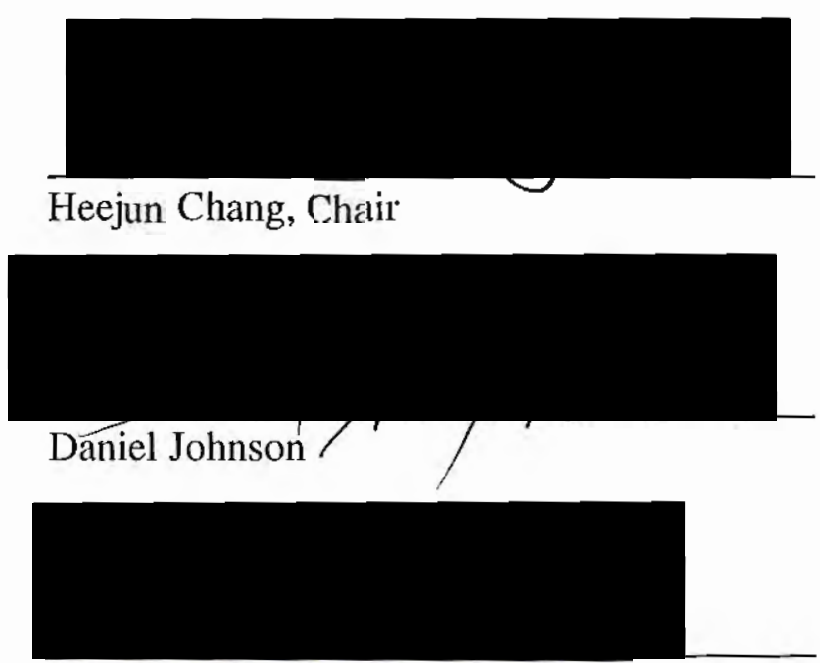

Teresa Bulman

DEPARTMENT APPROVAL:

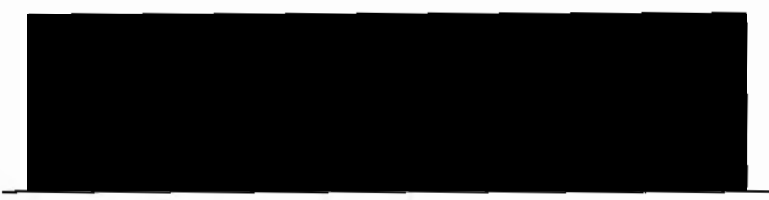

Martha Works, Chair

Department of Geography 


\title{
THE EFFECTS OF CLIMATE CHANGE AND URBANIZATION \\ ON THE RUNOFF OF THE ROCK CREEK BASIN
}

\author{
by \\ JON J. FRANCZYK
}

A thesis submitted in partial fulfillment of the requirements for the degree of

MASTER OF SCIENCE

in

GEOGRAPHY

Portland State University

2008 


\begin{abstract}
An abstract of the thesis of Jon J. Franczyk for the Master of Science in Geography presented March 4, 2008.
\end{abstract}

Title: The Effects of Climate Change and Urbanization on the Runoff of the Rock Creek Basin

Climate changes brought on by global warming are expected to have a significant affect on the Pacific Northwest hydrology during the $21^{\text {st }}$ Century. Current research anticipates higher mean annual temperatures and an intensification of the hydrological cycle. This is of particular concern for highly urbanized basins, which are considered more vulnerable to changes in climate. Because the majority of previous studies have addressed the influences of either climate or urban land cover changes on runoff, there is a lack of research investigating the combined effect of these factors. The Rock Creek basin (RCB), located in the Portland, OR, metropolitan area, has been experiencing rapid urban growth throughout the last 30 years, making it an ideal study area for assessing the affect of climate and land cover changes on runoff. Methods for this assessment include using a combination of climate change and land cover change scenarios for 2040 with the semidistributed AVSWAT-X (ArcVicw Soil and Water Assessment Tool) hydrological model to determine changes in mean runoff depths at the monthly, seasonal, and 
annual scales. Statistically downscaled climate change results from the ECHAM5 general circulation model (GCM) found that the region would experience an increase of $1.2^{\circ} \mathrm{C}$ in the average annual temperature and a $6 \%$ increase in average annual precipitation between 2030 and 2059. The model results revealed an amplification of runoff from either climate or urbanization. Projected climate change plus low-density, sprawled urban development for 2040 produced the greatest change to mean annual runoff depth $(+5.5 \%)$, while climate change plus higher-density urban development for 2040 resulted in the smallest change $(+5.3 \%)$, when compared to the climate and land cover of 2001 . The results of this study support the hypothesis that the combination of both climate change and urbanization would amplify the runoff from the RCB during the $21^{\text {st }}$ Century. This has significant implications for water resource managers attempting to implement adaptive water resource policies to future changes resulting from climate and urbanization. 


\section{ACKNOWLEDGEMENTS}

There are a number of people I would like to acknowledge, whose help made this thesis investigation possible. I wish to thank my advisor Dr. Heejun Chang for providing the knowledge, resources, motivation, and feedback that enabled me to see this project to the end. I would also like to thank my committee members Drs. Daniel Johnson and Teresa Bulman for providing valuable suggestions and advice during this process. Dr. Vivek Shandas also offered helpful recommendations during the initial stages of this project. The PSU faculty and fellow students in the Geography department deserve much appreciation for the extra support and friendship that helped me get through these last two-plus years. Finally, I would like to thank my family and Kasey for the love and support throughout the years and for putting up with me during my graduate studies. 


\section{TABLE OF CONTENTS}

ACKNOWLEDGEMENTS ........................................................................

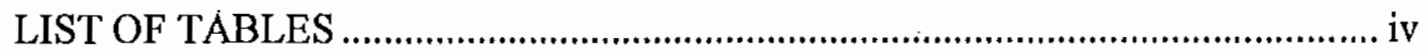

LIST OF FIGURES ................................................................................. vi

LIST OF ACRONYMS .......................................................................... viii

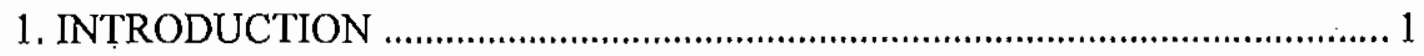

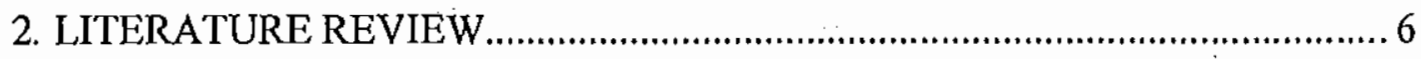

2.1. Land Use Affects on Watershed Hydrology .............................................6

2.1.1. Urbanization Thresholds......................................................................8

2.1.2. Location of Urbanization within a Watershed ......................................9

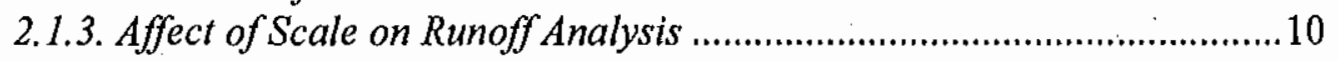

2.1.4. Hydrological Models....................................................................11

2.2. Climate Change Affects on Watershed Hydrology ..................................... 14

2.2.1. Climate Change and Runoff .............................................................. 14

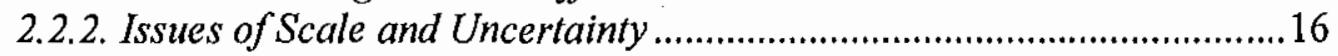

2.3. Land Use and Climate Change Affects on Watershed Hydrology ................ 18

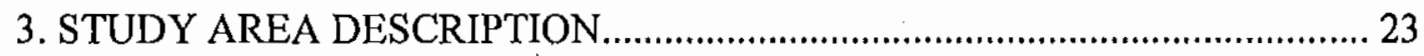

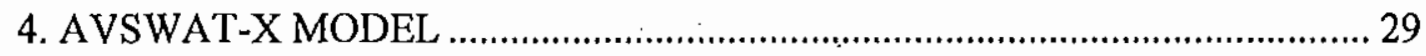

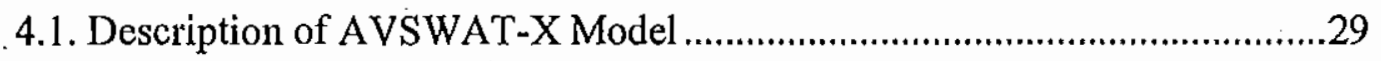

4.2. Applications of SWAT in Previous Research ...........................................36

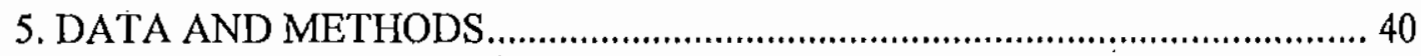

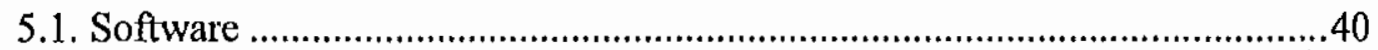

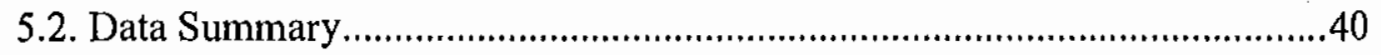

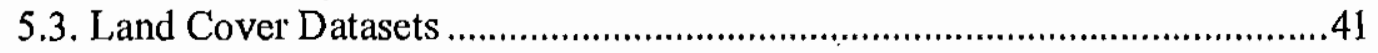

5.3.1. Current Land Cover .............................................................................4

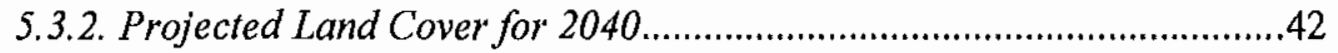

5.4. Climate Datasets..................................................................................45

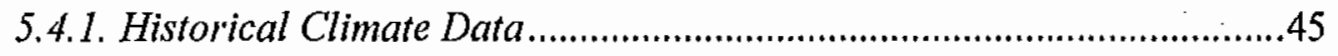

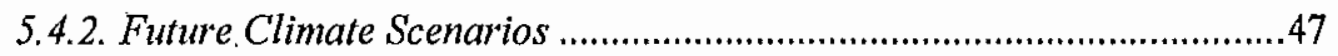

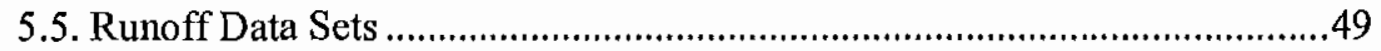

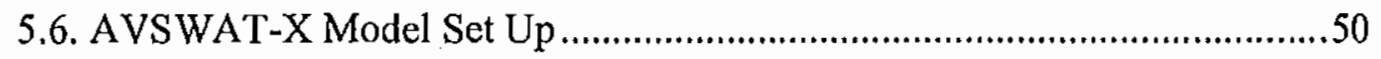

5.6.1. Automated Delineation of the $R C B$..................................................51

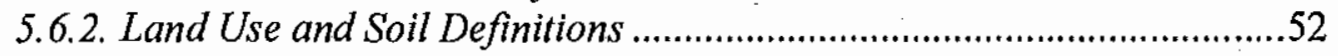

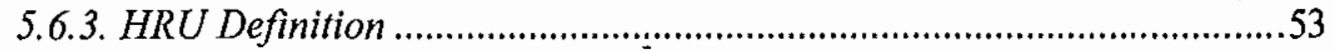

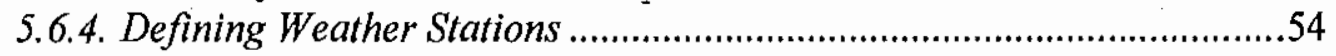

5.6.5. Building Initial Watershed Values ................................................5. 54 


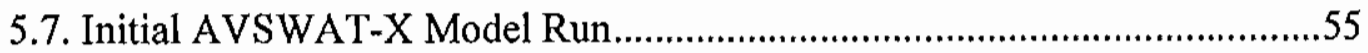

5.8 Model Calibration and Validation............................................................5

5.8.1. Automated Sensitivity Analysis ........................................................56

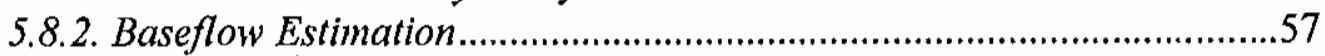

5.8.3. Model Calibration Methods ................................................................58

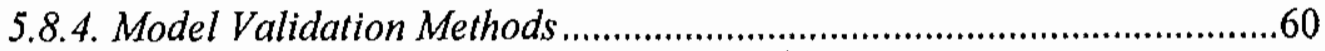

5.8.5. Statistical Measures of Model Accuracy ..................................................61

5.9. Modeling Changes in Land Cover and Climate for 2040 ..............................62

5.10. Methods for Evaluating Changes in RCB Runoff ......................................63

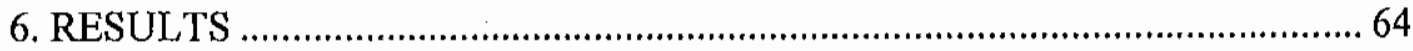

6.1. Model Calibration and Validation Results..................................................64

6.2. Modeled Changes to Climate for $2030-2059$...............................................66

6.3. Runoff Response to Land Cover and Climate Change Scenarios..................68

6.3.1. Runoff Response to Land Cover Change ..............................................68

6.3.2. Runoff Response to Climate Change .......................................................76

6.3.3. Runoff Response to Land Cover and Climate Change............................8

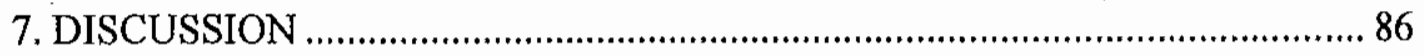

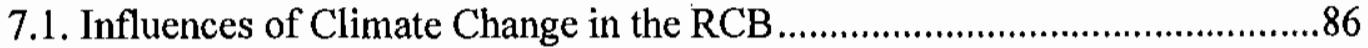

7.2. Influences of Land Cover Change in the RCB.............................................92

7.3. Effects of Climate Change and Urbanization..............................................99

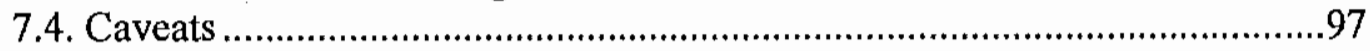

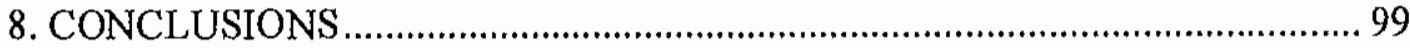

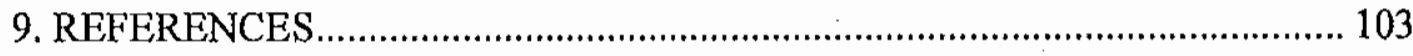

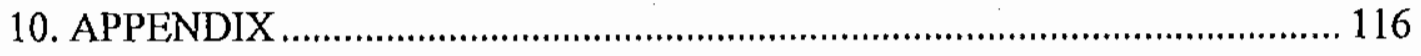




\section{LIST OF TABLES}

TABLE

PAGE

Table 1: Previous studies investigating the affect of urban growth on runoff

Table 2: Previous studies investigating the affect of climate change on runoff

Table 3: Previous studies investigating the combined affect of urban growth and climate change on runoff

Table 4: Previous studies using the SWAT model to investigate the affect of climate change on runoff

Table 5: Previous studies using the SWAT model to investigate the affect of urbanization on runoff

Table 6: Datasets included in the Rock Creek hydrological model

Table 7: Description of the three PNW-ERC land cover scenarios

Table 8: The percent and total area of each land category in the RCB for the baseline and PNW-ERC scenarios

Table 9: Climate gage stations used in study

Table 10: Changes in climate for the RCB for 2040, according to the ECHAM5 GCM output

Table 11: Characteristics of the STATSGO soil layer used in the RCB model

Table 12: SWAT model parameters adjusted during the calibration Process

Table 13: Statistical results of the initial run, calibration, and validation Process

Table 14: Mean total annual runoff depths produced by the baseline scenario and each of the PNW-ERC land change scenarios for 2040 with contemporary climate

Table 15: Mean annual ET volumes in the RCB for the baseline scenario and each of the PNW-ERC land scenarios

Table 16: Mean annual runoff depths produced by the baseline scenario and the baseline climate change scenario

Table 17: Mean annual ET volumes produced by the baseline scenario and the baseline climate change scenario

Table 18: Projected total and percent changes in mean seasonal runoff volumes $(\mathrm{cm})$ in the RCB for the baseline climate change scenario and each of the PNW-ERC land change scenarios with climate change, when compared to the baseline scenario 
Table 19: Projected total and percent changes in mean monthly runoff volumes $(\mathrm{cm})$ in the RCB for the baseline climate change scenario and each of the PNW-ERC land change scenarios for 2040 with climate change, when compared to the baseline scenario

Table 20: Mean total annual runoff volumes produced by the baseline and each of the PNW-ERC land change scenarios for 2040 with climate change 


\section{LIST OF FIGURES}

FIGURE

PAGE

Figure 1: A descriptive map of the Rock Creek Basin

Figure 2: Mean monthly precipitation and runoff for the Rock Creek basin between 2001 and 2005

Figure 3: Location of the Rock Creek basin relative to Portland, OR and the surrounding urban growth boundary

Figure 4: Procedure used by AVSWAT-X to model runoff

Figure 5: Comparison of flow modeled by the initial AVSWAT-X run and observed flow for $2001-2003$ at the Rock Creek stream flow measuring station, Highway 8

Figure 6: Comparison of calibrated flow and observed flow for $2001-$ 2003 at the Rock Creek stream flow measuring station, Highway 8

Figure 7: Comparison of validated flow and observed flow at the Rock Creek stream flow measuring station, Highway 8

Figure 8: Modeled absolute changes in seasonal precipitation between the baseline climate $(1973-2002)$ and the climate change scenario $(2030-2059)$

Figure 9: Modeled absolute changes in monthly precipitation between the baseline climate $(1973-2002)$ and the climate change scenario $(2030-2059)$

Figure 10: Map showing the urban development within the RCB as modeled by the Compact land-cover scenario

Figure 11: Map showing the urban development within the RCB as modeled by the Planned land-cover scenario

Figure 12: Map showing the urban development within the RCB as modeled by the Sprawl land-cover scenario

Figure 13: Modeled absolute changes in mean monthly runoff depths for the RCB for each of the PNW-ERC land change scenarios with contemporary climate, when compared to the baseline scenario

Figure 14: Modeled absolute changes in mean seasonal runoff depths for the RCB for each of the PNW-ERC land change scenarios with contemporary climate, when compared to the baseline scenario

Figure 15: Modeled absolute changes from the baseline scenario in mean seasonal ET for the PNW-ERC land cover scenarios

Figure 16: Modeled absolute changes from the baseline scenario in mean monthly ET for the PNW-ERC land cover scenarios 
Figure 17: Modeled absolute changes in mean monthly runoff depths for the RCB for the modeled baseline climate change scenario compared to the modeled baseline scenario

Figure 18: Modeled absolute changes in mean seasonal runoff depths for the RCB for the modeled baseline climate change scenario, when compared to the modeled baseline scenario

Figure 19: Modeled absolute change from the baseline scenario in mean monthly ET for the baseline climate change scenario

Figure 20: Modeled absolute change from the baseline scenario in mean seasonal ET for the baseline climate change scenario

Figure 21: Modeled absolute change in monthly ET volume from the baseline scenario for the baseline climate change scenario and the three PNW-ERC land cover scenarios with climate change

Figure 22: Modeled absolute change in seasonal ET volume from the baseline scenario for the baseline climate change scenario and the three PNW-ERC land cover scenarios with climate change

Figure 23: Modeled absolute changes in mean monthly runoff volume (cm) for the RCB for the baseline climate change scenario and each of the PNW-ERC land change scenarios with climate change, when compared to the baseline scenario with climate change

Figure 24: Modeled absolute changes in mean seasonal runoff volume (cm) for the RCB for the baseline climate change scenario and each of the PNW-ERC land change scenarios with climate change, when compared to the baseline scenario with climate change 


\section{LIST OF ACRONYMS}

$\begin{array}{ll}\text { Acronym } & \text { Definition } \\ \text { AVSWAT-X } & \text { ArcView Soil and Water Assessment Tool } \\ \text { BASINS } & \text { Better Assessment Science Integrating point and Non-point. } \\ & \text { Sources } \\ \text { CIG } & \text { Climate Impact Group } \\ \text { CN } & \text { SCS Curve Number } \\ \text { DEM } & \text { Digital Elevation Model } \\ \text { ECHAM5 } & \text { General Circulation Model used in study } \\ \text { ET } & \text { Evapotranspiration } \\ \text { GCM } & \text { General Circulation Model } \\ \text { GIS } & \text { Geographical Information System } \\ \text { HRU } & \text { Hydrological Response Unit } \\ \text { IPCC } & \text { International Panel of Climate Change } \\ \text { NHDPlus } & \text { National Hydrological Dataset } \\ \text { NLCD } & \text { National Land Cover Dataset } \\ \text { OCS } & \text { Oregon Climate Service } \\ \text { PET } & \text { Potential Evapotranspiration } \\ \text { PNW-ERC } & \text { Pacific Northwest Ecological Research Consortium } \\ \text { RCB } & \text { Rock Creek Basin } \\ \text { STATSGO } & \text { United States Soil Map } \\ \text { SWAT } & \text { Soil and Water Assessment Tool } \\ \text { UGB } & \text { Urban Growth Boundary } \\ \text { USDA } & \text { United States Department of Agriculture } \\ \text { USGS } & \text { United States Geological Survey } \\ \text { VIC } & \text { Variable Infiltration Capacity hydrology model }\end{array}$




\section{INTRODUCTION}

In the field of hydrology, there has been extensive research assessing the affect of either urbanization or climate change on watershed runoff. However, the combined effect of these two variables has been coming under increased scrutiny in recent years in order to assess the regional influence of climate change on developing watersheds. The hydrological characteristics of a watershed are dependent on a variety of factors, including the regional climate and the degree of development. Changes in either or both of these factors can significantly alter the volume and timing of runoff throughout the watershed. It follows that research attempting to assess the future availability of regional water resources would incorporate both aspects into their modeling methods.

The 2007 International Panel for Climate Change (IPCC) Fourth Assessment Report (FAR) has concluded that the global average surface air temperature has increased by $0.74^{\circ} \mathrm{C}$ during the $20^{\text {th }}$ Century and is projected to increase from 1.8 to $4.0^{\circ} \mathrm{C}$ by the year 2100 , relative to 1990 temperatures (IPCC 2007). It is widely recognized that these predicted temperature changes are expected to cause an intensification of the hydrologic cycle at global and regional scales (Huntington 2006). This intensification has the potential to produce changes in the temporal and spatial distribution of precipitation, increasing the frequency of storm intensities and flooding, causing more frequent droughts, and a decrease in annual snowfall (Georgiyevsky \& Shiklomanov 2003, Trenberth et al. 2003, 
Huntington 2006, IPCC 2007). There is evidence for increases in heavy precipitation events, droughts, and extreme temperatures across the globe during the 20th century, which is considered a good indicator of regional climate changes. (IPCC 2007, Nicholls and Alexander 2007). The consequences of climate change at the watershed scale are dependent on watershed characteristics, and it follows that the more stresses and demands placed on the system, the more vulnerable it could be to these changes (Arnell 2000). These stresses could include decreased runoff volumes or significant changes in the temporal and spatial distribution of runoff (Arnell 2004).

Land cover change within a watershed is recognized as an important factor affecting runoff, and it is possible that the transformation of land across the globe could have a greater influence on runoff than climate change (Vorosmarty et al. 2000). At the watershed scale, the influence of climate change on runoff can be further exacerbated by increased urban development, as well as other changes in land uses and vegetation (Georgiyevsky \& Shiklomanov 2003). In fact, Defries and Eshleman (2004) suggest that the hydrological impact of land use change is a major issue for the $21^{\text {st }}$ Century. Expanding impervious surfaces from urban growth contribute to reducing groundwater recharge and can increase the volume and flashiness of runoff (Dunne \& Leopold 1978, Schueler 1994). Palmer et al. (2004) stated that watersheds developed closer to their maximum sustainable level of use are considered the most vulnerable to changes in climate (Palmer et al. 2004). 
Globally, the urban population has increased by $100 \%$ throughout the last quarter of the $20^{\text {th }}$ Century (Chin 2006). This trend is expected to continue and nearly all of the population growth in the next 30 years is projected to occur in urban areas (Alig et al. 2004). One of the repercussions of this expansion will be the potential for significant impacts on local and regional water resources, thus reducing the resilience of their water supply systems (Dunne \& Leopold 1978, Schueler 1994). The ability to study the hydrological consequences of land use changes at various scales has been advancing at a rapid rate because of the increasing availability of satellite data for observing land use changes, as well as improvements in modeling capabilities (Defries and Eshleman 2004). Research that is able to reproduce the spatial and temporal extent of watershed processes while integrating new climate and land cover datasets will provide a valuable means for developing adaptable water resource management policies.

Watersheds throughout the Pacific Northwest (PNW) are expected to experience the affects of both climate change and urbanization during the $21^{\text {st }}$ Century. Climate projections for the PNW anticipate mean temperatures rising by approximately $1.5^{\circ} \mathrm{C}$ by 2020 and $2.3^{\circ} \mathrm{C}$ by 2040 when compared to the year 2000 . In addition, annual precipitation is expected to increase, primarily because of increased winter rainfall, while summers become drier, especially in the later summer months. This will translate into earlier spring runoff and declining summer stream flow trends (Palmer \& Hahn 2002, Mote et al. 2003, Snover et al. 2003, 
Palmer et al. 2004). Indeed, seasonal shifts in flow, not changes in total annual flow, are expected to have the greatest affect on the stream flow of rivers throughout the PNW (Mote et al. 2003, Graves and Chang 2007).

However, the influence of climate change must be considered against the backdrop of rapid regional land development. Since 1970, the population in the PNW has expanded at alınost twice the rate of the national average, significantly contributing to human influences on the hydrology of the region (Mote et al. 2003). This is particularly true in the larger urban centers, including Portland, OR. Population in the Portland Metropolitan Area, OR, especially within the Urban Growth Boundary (UGB), has more than doubled between 1950 and 2000 (Edmonston 2003). The high rate of urban growth in this region, combined with potential regional climate changes will have a significant influence on the runoff characteristics of local urbanizing watersheds.

In order to address these issues at the local scale, the objective of this study is to determine the affect of both climate change and urbanization on the volume and timing of runoff from the Rock Creek basin, OR. The study hypothesis states that the combination of climate change and urban growth will amplify the volume of runoff from the Rock Creek basin between 2030 and 2059, when compared to the contemporary period $(1971-2002)$. This analysis period was chosen based on the availability of projected climate and urban growth data for the region, as well as its similarity to comparative studies. The following research questions are 
considered: (1) What percentage and density of urban growth within the Rock Creek basin will induce the greatest changes in runoff? (2) How will projected urban growth influence runoff from the basin between 2030 and 2059? (4) What potential affect will a current regional climate change projection for $2030-2059$ have on the Rock Creek basin's runoff? (5) What will be the combined affect of urban growth and climate change on the runoff from the Rock Creek basin between 2030 and $2059 ?$

This thesis will contribute to hydrological research in two ways. First, it will investigate a local watershed using projections based on the most current regional climate and land use assessments and thus be useful to creating regional water management policies. Second, it will add to a small but growing body of research examining the combined influence of climate change and urbanization on watershed runoff.

This study will first review previous scientific research detailing how urbanization, climate change, and a combination of the two have been found to affect watershed runoff. Next, it will provide a description of the hydrological model and the data and methodology used in this assessment. Finally, the results will be summarized, followed by a discussion as to how they compare with other relevant studies and their significance to hydrological research. 


\section{LITERATURE REVIEW}

In order to address the combined affect of urbanization and climate change on runoff, this study will begin with reviewing literature concerning the affects of urbanization on watershed runoff, including the issues of thresholds, location, and modeling methods and uncertainties. Next, it will review the recent research for determining the affects of climate change on watershed runoff and will discuss the development and use of emission scenarios in GCMs, regionalization (downscaling), how different GCMs can provide different results, and the uncertainties involved in climate modeling. Finally, it will examine recent studies that have assessed the combined affects of urbanization and climate change and how the methods for assessing each phenomenon are combined.

\subsection{Land Use Affects on Watershed Hydrology}

It is well established that increased agricultural and urban land cover can produce modifications in evapotranspiration, runoff quality and quantity, and infiltration rates. After precipitation falls, it will do one of three things: (1) infiltrate into the ground, (2) evaporate into the air, or (3) run off into streams or rivers. As urbanization progresses, it inhibits or alters these processes by both increasing the amount of impervious surfaces and decreasing vegetation cover. Impervious surfaces, such as parking lots, buildings, roads, and sidewalks, can introduce changes in the timing and volume of local or regional runoff, increase peak 
discharges as a response to storm events, and create higher risk for flooding. As

urban land use expands, the removal of vegetation can cause a reduction in

evapotranspiration rates, thus increasing potential runoff. Table 1 lists the results of

select urbanization impact studies.

Table 1: Previous studies investigating the affects of urban growth on watershed runoff.

\begin{tabular}{|l|l|l|l|}
\hline Author & Study Area & Model & Results \\
\hline $\begin{array}{l}\text { Beighley \& } \\
\text { Moglen (2002) }\end{array}$ & $\begin{array}{l}\text { Baltimore- } \\
\text { Washington }\end{array}$ & $\begin{array}{l}\text { Empirical } \\
\text { (t-test, } \\
\text { Kendall's tau, } \\
\text { Spearman } \\
\text { Rank) }\end{array}$ & $\begin{array}{l}\text { Significant positive trend in discharge- } \\
\text { precipitation ratio for majority of 11 studied } \\
\text { watersheds }\end{array}$ \\
\hline $\begin{array}{l}\text { Moglen \& } \\
\text { Beighley } \\
(2002)\end{array}$ & $\begin{array}{l}\text { Washington } \\
\text { DC, USA }\end{array}$ & $\begin{array}{l}\text { Lumped } \\
\text { (TR-55) }\end{array}$ & $\begin{array}{l}\text { Two-year peak discharge doubled over 46- } \\
\text { year period as urban land use reached 57\% of } \\
\text { watershed }\end{array}$ \\
\hline $\begin{array}{l}\text { Niehoff et al. } \\
(2002)\end{array}$ & $\begin{array}{l}\text { Lein River, } \\
\text { Germany }\end{array}$ & $\begin{array}{l}\text { Distributed } \\
\text { (WaSiM- } \\
\text { ETH) }\end{array}$ & $\begin{array}{l}\text { Increases in peak runoff and flood volumes } \\
\text { due to urbanization more pronounced for } \\
\text { high-intensity, short-term storm events }\end{array}$ \\
\hline $\begin{array}{l}\text { Grove et al. } \\
(2001)\end{array}$ & Indiana, USA & $\begin{array}{l}\text { Lumped } \\
\text { (L-THIA) }\end{array}$ & $\begin{array}{l}\text { Related reduction of pervious surfaces to } \\
\text { increase in precipitation to runoff ratio and } \\
\text { mean annual runoff }\end{array}$ \\
\hline $\begin{array}{l}\text { Tang et al. } \\
\text { (2005) }\end{array}$ & $\begin{array}{l}\text { Muskegon } \\
\text { River, MI, } \\
\text { USA }\end{array}$ & $\begin{array}{l}\text { Lumped } \\
\text { (L-THIA) }\end{array}$ & $\begin{array}{l}\text { A 25\% increase in mean annual runoff } \\
\text { volunes for areas of unchecked urban growth } \\
\text { by 2040 }\end{array}$ \\
\hline $\begin{array}{l}\text { Pinter et al. } \\
(2006)\end{array}$ & $\begin{array}{l}\text { Rhine River, } \\
\text { Germany }\end{array}$ & $\begin{array}{l}\text { Empirical } \\
\text { (Regression) }\end{array}$ & $\begin{array}{l}\text { Related 65\% increase in urban area with shift } \\
\text { in rainfall-runoff relationship }\end{array}$ \\
\hline Chang (2007) & $\begin{array}{l}\text { Portland, OR, } \\
\text { USA }\end{array}$ & $\begin{array}{l}\text { Empirical } \\
\text { (Kendall's } \\
\text { tau, t-test, } \\
\text { Kruskall- } \\
\text { Wailis) }\end{array}$ & $\begin{array}{l}\text { Urbanized watersheds displayed significantly } \\
\text { shorter durations of storm runoff and lower } \\
\text { base-flow }\end{array}$ \\
$\begin{array}{l}\text { Empirical } \\
\text { (Regression) }\end{array}$ & $\begin{array}{l}\text { Urbanization explained significant increase in } \\
\text { peak flows and annual nunoff depth }\end{array}$ \\
\hline $\begin{array}{l}\text { Olivia \& } \\
\text { Defee (2007) }\end{array}$ & Texas, USA \\
\hline
\end{tabular}




\subsubsection{Urbanization Thresholds}

It has been determined that there is an approximate percentage of urbanization that must occur within a watershed before there is a significant change in its runoff regime. Several studies, using empirical and/or physical modeling methods, have concluded that impervious surfaces must exceed a threshold of $10 \%$ to $20 \%$ of the total watershed area before significant modifications in watershed characteristics occur, including a potential $200-500 \%$ increase in estimated runoff (Schueler 1994, Beighley \& Moglen 2002, Booth et al. 2002, Chin 2006, White \& Greer 2006). In regards to water quality, which is in part dependant on runoff volume, the U.S. Environmental Protection Agency has considered watersheds with approximately $10 \%$ impervious area as "unable to support a high quality stream system" (Olivera \& DeFee, 2007, p. 180). Using regression models, Olivera \& DeFee (2007) examined runoff depths throughout developed areas of the Whiteoak Bayou, TX, and found that, once the amount of impervious surfaces within the watershed reached $10 \%$, a positive linear relationship between runoff and increasing urban growth developed. This resulted in an increase in annual runoff depths and peak flows ( $146 \%$ and $159 \%$, respectively). One conclusion of this study was that, at this threshold, the watershed had exceeded its capacity to assimilate land changes and continue to maintain its natural runoff patterns. Booth et al. (2002) revealed that river discharges in King County, Washington, were affected well below the $10 \%$ threshold when a significant proportion of the 
watershed was simultaneously cleared of forest, indicating that this threshold can also be influenced by the combined effect of cleared land and increased impervious surfaces.

\subsubsection{Location of Urbanization within a Watershed}

The location of urban growth within a watershed can also influence localized modifications in the timing and volume of runoff by concentrating the impervious surfaces and/or increasing the connectivity between storm drainage pathways. By analyzing runoff changes at the sub-watershed scale, the analysis of the Whiteoak Bayou, TX by Olivia \& DeFee (2007) revealed that the highest change in watershed response over time occurred as patches of urban land cover became interconnected through continued growth, what they called "landscape saturation." This interconnection allowed for the increased conveyance of runoff throughout the watershed and coincided with increased annual runoff depths and peak flows. Schueler (1994) indicated that creating higher-density urban clusters instead of sprawl will minimize the influence of impervious surfaces on stream flow fluctuations. In fact, Scheuler (1994) and Moglen and Kim (2007) both conclude that developing urban "centers" or concentrations of urbanization within a watershed will have smaller negative affects on runoff than low-density urban growth. Finally, development should ideally occur closer to the main channel downstream from the headwaters so that runoff contributions from urban land will have a smaller influence on the overall basin stream flow (Moglen and Kim 
2007). This was also expressed in Bosch et al. (2003) where modeled high-density development in the headwaters of the Black Creek watershed, Virginia, USA (145

$\mathrm{km}^{2}$ ) showed a higher affect on peak response for storms (<1-year) when compared to development in the middle of the watershed or at the outlet.

\subsubsection{Affect of Scale on Runoff Analysis}

Establishing the direct source of changes to watershed runoff becomes more complex at a larger spatial scale. In a study of the Camel watershed $\left(210 \mathrm{~km}^{2}\right)$, UK, Sullivan et al. (2004) showed that between 1965 and 2000, long-term alterations in the runoff response were the result of the combination of variations in climate, increased agricultural activity and urban expansion. This research emphasized the difficulties in determining the direct effects of changes in multiple land uses on flood events at the basin scale. Their reasoning concluded that, for larger . watersheds, existing water storage mechanisms, the spatial extent and location of urban growth, and the runoff response of sub-watersheds all help to determine the influence of urbanization (Sullivan et al. 2004, Wheater 2006). As underlined by Tollan (2002) and Chang (2003), land modifications within small watersheds have the greatest affect on changes in stream flow and potential flooding. Moglen and Beighley (2002) also stressed that, while measurements of peak discharge at the watershed outlet may reflect overall land changes throughout the basin, in a watershed that contains spatially varied densities in urban cover, individual sub- 
basins may show a greater or lesser affect because of different levels of impervious surfaces.

\subsubsection{Hydrological Models}

Hydrologic research has employed different methods for assessing the influence of urbanization on watershed hydrology. Typically, this is accomplished through the use of models designed to represent real world water resource systems and processes. There are several different types of hydrological models available, the choice of which is dependent upon the study purpose, as well as data availability, time scale and cost. Empirical models, which are typically based on statistical analysis such as linear or multiple regressions, are generally not designed to explain physical processes, but to depict how the water resource system behaves. For example, they have been used to analyze whether trends in measures of historic runoff, such as mean annual runoff, mean seasonal runoff ratio, and/or annual peak runoff ratio, are influenced by urban land development. One of the primary advantages of empirical models is that they are relatively simple; however, the validity of data relationships and final results must be well-understood or significant error can be introduced.

Conceptual models characterize basic processes occurring within the hydrological system through apparent behaviors. Typically, they represent the system as a series of stores and fluxes, each signifying different aspects of the natural character and/or man-made infrastructure (i.e. reservoirs) within the 
watershed. They can be designed to simulate the operation of reservoir systems, such as calculating seasonal or annual yield, and are used extensively in water resource planning. Finally, physically-based models represent many of the physical processes that take place within the watershed and are much more detailed than the previous modeling methods. These include lumped, semi-distributed, and distributed model types. They are useful for more detailed analysis, such as assessing groundwater pollution and designing flood defenses, as well as predicting watershed behavior under various conditions. These advantages can be offset by the complexity of model design and data requirements (Watts 1997, Lyon 2003, Singh and Frevert 2006).

The scale of study is also important in selecting the type of hydrological model to be used. Lumped models treat the watershed as one unit, with parameters spatially averaged together to form a simple representation of hydrologic processes. One example of the good use of this approach is the use of temperature data from only one weather station and extrapolating the data throughout an entire watershed. A disadvantage is that typically the runoff results are only verifiable at the outlet, and cannot characterize how water moves within the watershed itself. Distributed models are typically physically-based and represent the watershed as a grid, with each grid cell representing hydrological characteristics specific to that cell (e.g., precipitation or evapotranspiration). In this way, the watershed is represented in much more detail and spatial changes throughout the basin can be determined. A 
disadvantage of this approach is that they are much more complex than lumped models, have significant data requirements, and their computation time is longer. Semi-distributed hydrological models combine the advantages of each form of model. They divide the watershed into smaller, homogeneous units (sub-basins), whose averaged values are then aggregated at various points throughout the watershed. Increasingly, the distributed and semi-distributed-parameter models are preferred because of their ability to include more watershed system details, which increases the accuracy of their runoff calculations (Watts 1997).

As the integration of water resource models with Geographical Information Systems (GIS) has continued to evolve, numerous governmental and research organizations have developed predictive hydrological models that have been used in assessing the affects of climate and land use changes on hydrological characteristics at the watershed scale. Model examples include the Soil and Water Assessment Tool (SWAT) hydrology model, developed by the USDA and used extensively in impact studies for climate change (Jha et al. 2004, Thomson et al. 2005, Zhang et al. 2007) and land change (Chen et al. 2005) assessments; and the Variable Infiltration Capacity (VIC) macroscale hydrology model, developed at the University of Washington, and employed in numerous climate change impact studies in the western U.S. (Christensen et al. 2004, VanRheenen et al. 2004, Vicuna et al. 2007). The ability to incorporate spatial data, visually display and analyze watershed characteristics, and produce quality maps of model outputs are 
just some of the advantages of using a GIS interface (Lyon 2003, Martin et al. 2005). Disadvantages include model complexity and a lack of available data or high-resolution data (Grove et al. 2001). A certain degree of uncertainty is also inherent in the modeling process because of the simplification of complex hydrologic processes built into the model (DeWalle et al. 2000, Niehoff et al. 2002).

\subsection{Climate Change Affects on Watershed Hydrology}

\subsubsection{Climate Change and Runoff}

In addition to population growth and land use changes, the affect of climate change on water resources is becoming a fundamental concern for water managers and policy makers (Vorosmarty et al. 2000, Hall et al. 2003, Means III et al. 2003): Numerous studies over the past several decades have attempted to assess the affects it would have at the watershed level for various regions of the world. For example, in the Western United States, VanRheenen et al. (2003) determined that, in general, two watershed types have the greatest risk of being affected by climate change. These include basins that are dependent on winter rainfall and spring snowmelt, common in the Pacific Northwest and called "Transient" watersheds, and those that are highly developed and located in the Southwest and Western region of the country, because of increased water demand and vulnerability to even small droughts. Although there have been many research studies investigating the runoff response of watersheds to potential changes in temperature and precipitation due to 
global warming (IPCC 2007), this review focuses primarily on studies completed within the $21^{\text {st }}$ Century. Table 2 lists the results of select studies regarding climate change impacts on watershed runoff.

Table 2: Previous studies investigating the impacts of climate change on watershed runoff.

\begin{tabular}{|c|c|c|c|c|c|}
\hline Author & $\begin{array}{l}\text { Study } \\
\text { Area }\end{array}$ & GCM & $\begin{array}{l}\text { Study } \\
\text { Period }\end{array}$ & Model & Results \\
\hline $\begin{array}{l}\text { Christensen } \\
\text { et al. }(2004)\end{array}$ & $\begin{array}{l}\text { Colorado } \\
\text { River, } \\
\text { USA }\end{array}$ & $\mathrm{PCM}$ & $\begin{array}{l}1950- \\
1999 \\
2010- \\
2098\end{array}$ & $\begin{array}{l}\text { Distributed } \\
\text { (VIC) }\end{array}$ & $\begin{array}{l}\text { Annual runoff reduced by up } \\
\text { to } 17 \% \text { and water resource } \\
\text { system performance show up } \\
\text { to } 40 \% \text { reduction }\end{array}$ \\
\hline $\begin{array}{l}\text { VanRheenen } \\
\text { et al. }(2004)\end{array}$ & $\begin{array}{l}\text { California, } \\
\text { USA }\end{array}$ & PCM & $\begin{array}{l}1995- \\
2099\end{array}$ & $\begin{array}{l}\text { Distributed } \\
\text { (VIC) }\end{array}$ & $\begin{array}{l}\text { A greater reduction in stream } \\
\text { flow and stronger seasonal } \\
\text { shift in runoff in southern } \\
\text { basins compared to northem } \\
\text { ones }\end{array}$ \\
\hline $\begin{array}{l}\text { Jha et al. } \\
(2006)\end{array}$ & $\begin{array}{l}\text { Upper } \\
\text { Mississippi } \\
\text { River, } \\
\text { USA }\end{array}$ & $\begin{array}{l}\text { CSIRO } \\
\text { CCC, } \\
\text { CCSR, } \\
\text { GFDL, } \\
\text { HadCM3 }\end{array}$ & $\begin{array}{l}1968- \\
1997, \\
2061 \\
2090\end{array}$ & $\begin{array}{l}\text { Distributed } \\
\text { (SWAT) }\end{array}$ & $\begin{array}{l}\text { Resuits generally indicated an } \\
\text { increase in runoff, } \\
\text { particularly in winter } \\
\text { (increased precipitation) and } \\
\text { spring (increased snowmelt). }\end{array}$ \\
\hline $\begin{array}{l}\text { Graham et } \\
\text { al. }(2007 \mathrm{a})\end{array}$ & Sweden & $\begin{array}{l}\text { HIRHAM } \\
\text { (RCM) }\end{array}$ & $\begin{array}{l}1961- \\
1990 \\
2071- \\
2100\end{array}$ & $\begin{array}{l}\text { Semi- } \\
\text { Distributed } \\
\text { (HBV) }\end{array}$ & $\begin{array}{l}\text { Increased annual river flows } \\
\text { and earlier spring peak flows } \\
\text { from snow melt }\end{array}$ \\
\hline $\begin{array}{l}\text { Thodsen } \\
\text { (2007) }\end{array}$ & Holland & $\begin{array}{l}\text { HIRHAM } \\
\text { (RCM) }\end{array}$ & $\begin{array}{l}2071- \\
2100\end{array}$ & $\begin{array}{l}\text { Lumped } \\
\text { (NAM) }\end{array}$ & $\begin{array}{l}\text { Observed a } 7 \% \text { increase in } \\
\text { mean annual precipitation } \\
\text { and a } 12 \% \text { increase in mean } \\
\text { annual runoff }\end{array}$ \\
\hline $\begin{array}{l}\text { Vicuna et al. } \\
(2007)\end{array}$ & $\begin{array}{l}\text { Central } \\
\text { Valley, } \\
\text { CA, USA }\end{array}$ & $\begin{array}{l}\text { PCM, } \\
\text { HadCM3 }\end{array}$ & $\begin{array}{l}1961- \\
1999 \\
2020- \\
2049, \\
2070- \\
2099\end{array}$ & $\begin{array}{l}\text { Distributed } \\
\text { (VIC) }\end{array}$ & $\begin{array}{l}\text { Reduced stream flow caused } \\
\text { by decreased precipitation } \\
\text { and late spring snow pack by } \\
\text { late } 21^{\text {st }} \text { Century }\end{array}$ \\
\hline
\end{tabular}

PCM $=$ Parallel Climate Model, US National Centre for Atmospleric Research $\mathrm{CSIRO}=$ Australian Commonwealth Scientific and Industrial Research Organization $\mathrm{CCC}=$ Canadian Centre for Climate Modeling and Analysis, Canada $\mathrm{CCSR}=$ Japanese Centre for Climate Systems Research GFDL $\approx$ US Geophysical Fluid Dynamics Laboratory HadCM3 = UK Hadley Centre for Climate Prediction and Research NCAR-DOE = US National Centre for Atmospheric Research HIRHAM = Max Planck Institute for Meteorology 


\subsubsection{Issues of Scale and Uncertainty}

GCMs are able to generate large spatial climate projections, but their accuracy diminishes at the regional or river basin scale necessary for water resource research (Varis et al. 2004, Giorgi 2005). Krysanova et al. (2007) set the resolution threshold necessary for effective use in macroscale hydrology models at 10km, a level of accuracy not yet attainable by current GCMs. Because the higher resolution climate data are necessary for watershed studies, "regionalization" of GCM outputs has been developed using statistical or dynamic downscaling methods in an attempt to resolve this mismatch (Xu 1999, Varis et al. 2004, IPCC 2007). Statistical downscaling involves finding the statistical relationships between the large-scale climatic variables, regional physiographic characteristics, such as topography, and gage observations. This can be accomplished through the use of weather generators, transfer functions, or weather typing schemes. Dynamic downscaling is physically-based and developed using similar mathematical techniques as those of GCMs, but at a higher grid resolution. Dynamic methods require greater amounts of computer power than statistical methods, but can achieve a much greater resolution (Xu 1999, Varis et al. 2004, Krysanova 2007). In studies comparing two downscaling methods of NASA's GISS GCM, the multiple linear regression model and MM5 dynamical model, Spak et al. (2007) found no significant difference in their ability to reproduce historical regional temperature parameters throughout North America. However, each method developed very different spatial 
temperature patterns when projecting future climate. Using the Parallel Climate Model (PCM) GCM, Wood et al. (2004) emphasized the need for bias correction step for both statistical methods (BCSD - Bias-Corrected and Spatial Disaggregation) and a dynamic RCM in order to produce similar acceptable results.

The degree of uncertainty in GCM outputs increase as the model resolution increases (Giorgi 2005). Uncertainty in the results of GCMs is attributed to (1) model configuration, or the mathematical representations of climate, (2) internal model variability, and (3) realistically reproducing the stochasticity of future natural climate. It is important to note that when uncertainty in the temperature results derived from GCMs is combined with the uncertainty inherent in hydrological models, they can produce an increasing or "cascading" effect (Giorgi 2005). Although there is general agreement within the scientific community on the degree of global temperature increases projected by GCMs, there is less confidence surrounding projected changes in precipitation amounts and seasonal variations, particularly at the local and regional scale (Giorgi 2005, Barnett et al. 2006, IPCC 2007). This can also be of particular importance in mountainous basins where the climate is more variable versus basins with more homogeneous climates (Bergstrom et al. 2001). The primary method used in the past for reducing uncertainty in climate change assessments is by using multiple GCMs in order to get a range of temperature and/or precipitation parameters (IPCC 2007). Once downscaled, the RCM is considered to have significantly reduced uncertainty when 
compared to the original GCM (Hingray et al. 2007). Finally, Graham et al. (2007b) discovered that using different RCMs based on one GCM had less of a hydrological impact than using RCMs derived from multiple GCMs.

The choice of GCM used in research can also influence the study results, particularly at the regional scale. While assessing the influence of climate change on global water resources using six climate models, Arnell (2004) showed inconsistencies among precipitation results from each model. In East Asia, two of the models used (HadCM3 and ECHAM4) simulated increases in precipitation, while the remaining four (CSIRO-Mk2, CGCM2, GFDL-r30, and CCSR) simulated decreases. This also occurred in Eastern North America, where three GCMs predicted increases, while the other three predicted the opposite. Some GCMs are considered "wetter" or "drier" because of their general tendency to produce higher or lower precipitation amounts, when compared to other climate models (Vicuna \& Dracup 2007). In fact, studies by Jha et al. (2006), Wilby et al. (2006), Graham et al. (2007a) and Thodsen (2007) all reported that their choice of GCMs in their research methodologies greatly influenced the runoff results from their hydrologic models.

\subsection{Land Use and Climate Change Affects on Watershed Hydrology}

The majority of previous hydrology studies have not focused on measuring the combination of land-use and climate change affects on watershed runoff. However, increasing expansion of the human footprint on the land has driven new 
research concerning this topic. The complex interactions between changes in climate and urbanization should be included in water availability assessments, as both factors can significantly alter the hydrology of a watershed (DeWalle et al. 2000). For example, as warmer temperatures associated with climate change are predicted to enhance ET, this could bring about a reduction in groundwater recharging. When further exacerbated by expanding impervious surfaces, the combination could lead to record low flows in urban streams. However, more impervious surfaces within a watershed could also offset the increase in ET from temperature and potentially minimize the impact from either factor (Hejazi and Moglen 2007). Urbanization may also enhance the volume and timing of runoff produced by the increasingly variable and intense precipitation events expected to occur under climate changes (Huntington 2006), thus contributing to flashier runoff and more flooding (Reynard et al. 2001, Choi 2004). In fact, Choi (2004) reported that, when compared to rural basins, urbanizing watersheds exhibited a greater maximum change in runoff from climate change.

Studies that address this combination typically assess either (1) the sensitivity of river runoff to changes in climate and land cover or (2) the magnitude of the combination of these factors on runoff. The methods used for assessing the affects of climate and land use on runoff have been varied. Barlage et al. 2002, Chang 2003, and Chen et al. (2005) all employed physically based hydrological models that effectively simulated the affects of changes in both climate and land 
use on basin hydrology characteristics. In Barlage et al. (2002) and Chang (2003), inputs to their models included scenarios that projected changes in climate and/or scenarios that projected changes in land-cover. By inputting each scenario separately or combining different climate projections with land cover scenarios, they were able to determine whether changes in climate, land cover, or both would potentially have the greatest affect on watershed runoff. Chen et al. (2005) used a similar methodology as the two previous studies; however, their focus was to separate the influence of historical climate variation and land cover change from the runoff of the Suomo basin, China from 1960 to 1999 . The study found that climate change, not land development, contributed the most to runoff fluctuations over the forty-year period. By using an equation describing the water budget for a river basin, Claussens et al. (2006) empirically determined stream flow changes in the Ipswich River Basin, MA based on calculated variations in ET caused from the combination of changes in climate and land use. Table 3 summarizes the results of selected studies regarding the combined climate change and urbanization influences on watershed runoff. 
Table 3: Previous studies investigating the combined affect of urban growth and climate change on watershed runoff.

\begin{tabular}{|c|c|c|c|c|c|}
\hline Author & $\begin{array}{c}\text { Study } \\
\text { Area }\end{array}$ & GCM & $\begin{array}{l}\text { Study } \\
\text { Period }\end{array}$ & Model & Results \\
\hline $\begin{array}{l}\text { Barlage et } \\
\text { al: (2002) }\end{array}$ & $\begin{array}{l}\text { Michigan, } \\
\text { USA }\end{array}$ & HadCM2 & $\begin{array}{l}1994- \\
2003 \\
2090- \\
2099\end{array}$ & $\begin{array}{l}\text { Distributed } \\
\text { (BATS } \\
\text { HYDRO) }\end{array}$ & $\begin{array}{l}\text { Results showed } 4.3 \% \text { increase } \\
\text { in precipitation-runoff ratio } \\
\text { and a decrease in surface } \\
\text { evaporation, } 2.5 \% \text { from } \\
\text { climate change and } 1.6 \% \text { from } \\
\text { land use }\end{array}$ \\
\hline $\begin{array}{l}\text { Chang } \\
(2003)\end{array}$ & $\begin{array}{l}\text { Pennsylva } \\
\text { nia, USA }\end{array}$ & $\begin{array}{l}\text { CCC, } \\
\text { HadCM2 }\end{array}$ & $\begin{array}{l}1970= \\
1990 \\
2025 \\
2034\end{array}$ & $\begin{array}{l}\text { Semi- } \\
\text { Distributed } \\
\text { (AVG } \\
\text { WLF) }\end{array}$ & $\begin{array}{l}\text { Climate change will have } \\
\text { greater impact on mean annual } \\
\text { stream flow than urbanization }\end{array}$ \\
\hline $\begin{array}{l}\text { Chen et al. } \\
(2005)\end{array}$ & $\begin{array}{l}\text { Upper } \\
\text { Yangtze } \\
\text { River, } \\
\text { China }\end{array}$ & None & $\begin{array}{l}1970 \\
1986, \\
1999\end{array}$ & $\begin{array}{l}\text { Lumped } \\
\text { (CHARM), } \\
\text { Distributed } \\
\text { (SWAT) }\end{array}$ & $\begin{array}{l}\text { Climate change had greater } \\
\text { impact }(60-80 \%) \text { on mean } \\
\text { annual stream flow than land } \\
\text { cover }(\sim 20 \%) \text {. }\end{array}$ \\
\hline $\begin{array}{l}\text { Claussens } \\
\text { et al. } \\
(2006)\end{array}$ & $\begin{array}{l}\text { Massachu } \\
\text { setts, USA }\end{array}$ & $\begin{array}{l}\mathrm{CCC}, \\
\text { HadCM2 }\end{array}$ & $\begin{array}{l}1931- \\
1998, \\
2101\end{array}$ & $\begin{array}{l}\text { Water } \\
\text { Balance, } \\
\text { Emperical } \\
\text { (Kendall's } \\
\text { tau) }\end{array}$ & $\begin{array}{l}\text { Increase of residential land use } \\
\text { to } 50.5 \% \text { in watershed } \\
\text { combined with climate change } \\
\text { causes up to } 22 \% \text { increase in } \\
\text { stream flow by } 2101\end{array}$ \\
\hline $\begin{array}{l}\text { Samanieg } \\
\text { o \& } \\
\text { Bardossy } \\
(2006)\end{array}$ & Germany & CGCM1 & $\begin{array}{l}1961- \\
2025\end{array}$ & $\begin{array}{l}\text { Emperical } \\
\text { (non-linear } \\
\text { functions) }\end{array}$ & $\begin{array}{l}\text { Annual peak event volume } \\
\text { increased between } 15 \% \text { and } \\
43 \% \text {, compared to reference } \\
\text { period under combined } \\
\text { scenarios. Higher urban } \\
\text { densification produces longer } \\
\text { duration high-volume flows } \\
\text { from winter storm events }\end{array}$ \\
\hline $\begin{array}{l}\text { Hejazi \& } \\
\text { Moglen } \\
(2007)\end{array}$ & $\begin{array}{l}\text { Maryland, } \\
\text { USA }\end{array}$ & $\begin{array}{l}\text { CCC, } \\
\text { HadCM3 }\end{array}$ & $\begin{array}{l}1946- \\
2000 \\
2000- \\
2099\end{array}$ & $\begin{array}{l}\text { Emperical } \\
\text { (regression) }\end{array}$ & $\begin{array}{l}\text { Individually, climate \& } \\
\text { urbanization produced no low- } \\
\text { flow trends (CCC) \& } \\
\text { increasing trends (HadCM3) } \\
\text { in future projections; jointly, } \\
\text { low-flow trends increased } \\
\text { (CCC) or showed no trend } \\
\text { (HadCM3) }\end{array}$ \\
\hline
\end{tabular}

CGCM1 = Canadian Centre for Climate Modelling and Analysis, Canada

HadCM2 = UK Hadley Centre for Climate Prediction and Research

$\mathrm{CCC}=$ Canadian Centre for Clinate Modeling and Analysis, Canada 
Through the use of land cover datasets based on established regional or local projections, study results can provide greater value to stakeholders for evaluating potential land change affects on local watershed runoff. For example, Barlage et al. (2002) developed the future land use scenario for the Huron River Watershed, MN using the 2020 master plan created by the Southeastern Michigan Council of Governments. Likewise, Chang (2003) used future urban growth projections within the Conestoga River Basin, PA proposed by the Lancaster County Planning Commission to develop an urban growth scenario. By using locally created growth projections, impact studies can have a more practical and localized application by local governments.

While the majority of studies mentioned here have determined that increasing temperature and precipitation will have a greater influence on watershed runoff than urbanization, it is acknowledged that urban growth will enhance the effect of these climate changes (Barlage et al. 2002, Chang 2003, Chen et al. 2005, Hejazi \& Moglen 2007). Understanding the influence of and interactions between climate and land use change on river runoff is an important goal toward assuring the future availability of water and the development of resilient water resource management policies. 


\section{STUDY AREA DESCRIPTION.}

The Rock Creek basin (RCB) (Figure 1) is a low-elevation, rain-fed watershed located in the western portion of the Portland metropolitan area in Washington County of Oregon. It encompasses $194.8 \mathrm{~km}^{2}$ with an elevation range from $386 \mathrm{~m}$ in the Tualatin Mountains to $36 \mathrm{~m}$ at the mouth of Rock Creek in the city of Hillsboro. Rock Creek is a tributary of the Tualatin River (RM 38.1) and is approximately $30 \mathrm{~km}$ in length. It is composed of four primary streams, including the Rock Creek mainstem, Bronson Creek, Beaverton Creek, and Johnson Creek. The choice of the RCB as the study area for this assessment is because of its high level of urbanization and increasing vulnerability to climate changes (Palmer et al. 2004). 


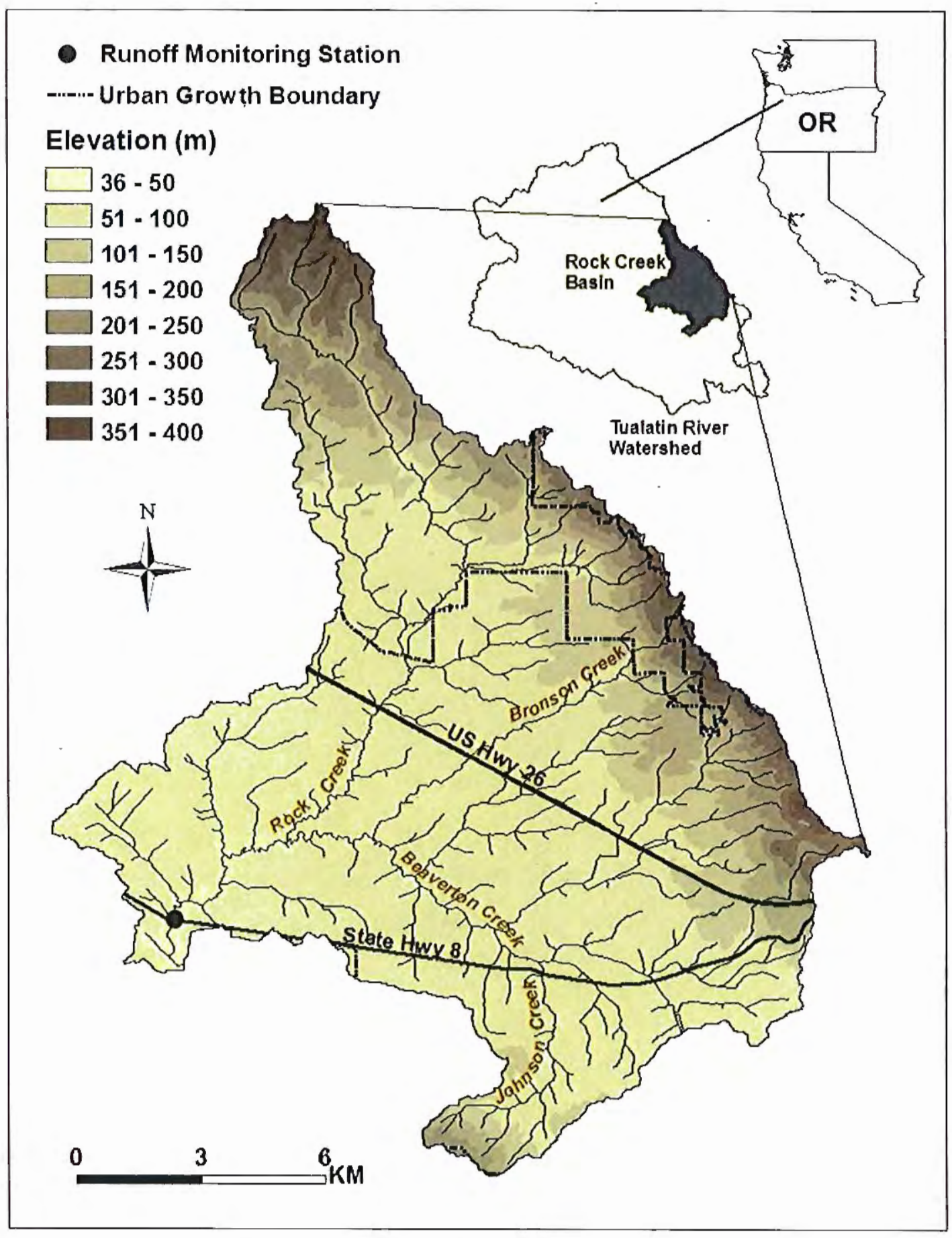

Figure 1: A descriptive map of the Rock Creek basin. 
The climate in the RCB is characteristic of a modified marine climate, with moderate year-round temperatures and a prevailing westerly flow. It is characterized by wet, mild winters and dry, warm summers. The basin is approximately $64 \mathrm{~km}$ (40 mi) from the Pacific Ocean, which accounts for mild average annual temperatures of $11.3^{\circ} \mathrm{C}$ and mean annual precipitation of approximately $109.5 \mathrm{~cm}$ (OCS 2007). The majority of precipitation falls from November through April, primarily in the form of rain. Snowfall is generally not a contributing factor to winter stream flows of Rock Creek. Figure 2 shows the mean monthly stream flow and precipitation for the RCB region for $2001-2005$. This illustrates Rock Creek's high winter flows and diminishing summer flows that characterize the seasonal variations in runoff.

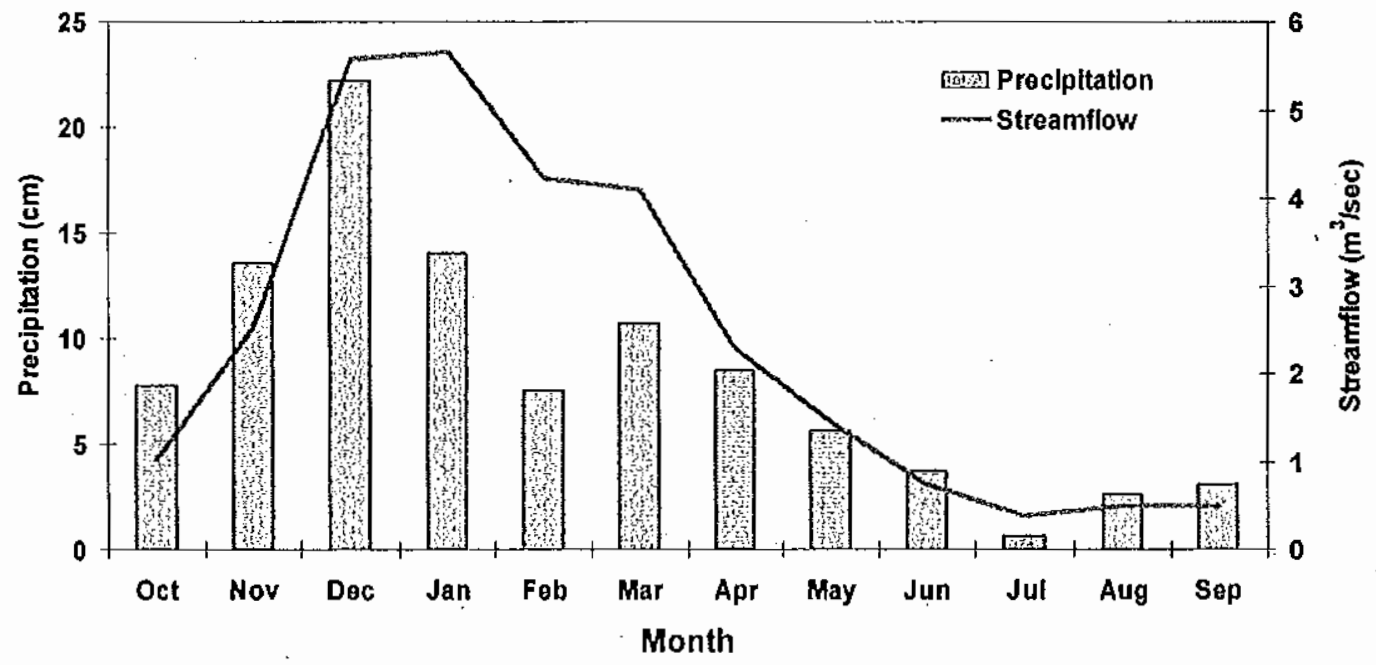

Figure 2: Mean monthly precipitation and runoff for the Rock Creek basin between 2001 and 2005 . 
Older Lucustrine silt/clay and fluvial deposits that line the Tualatin Valley floor and originate from the Missoula Floods characterize the geology of the RCB. Closer and into the Tualatin Mountains, there is a mixture of Columbia River basalts and sedimentary formations. Floodplain deposits are found around parts of Beaverton Creek, and small regions of Boring Lava deposits are located in the southeastern section of the Tualatin Mountains (Hawksworth 2001). Major soil classifications found within the watershed include Cascade silt loam (23\%), Aloha silt loam (19\%), Cornelius and Kinton silt loam (10\%), Woodburn silt loam (9\%), and Helvetia silt loam (7\%). Thirty soil classifications ranging from $0.01 \%$ to $3.8 \%$ comprise the remaining $32 \%$ of the watershed.

The larger population centers of the $\mathrm{RCB}$ are located primarily in the southern region, along the Tualatin Valley floor. The majority of the land area of the cities of Beaverton and Hillsboro is found within the urban growth boundary in the Rock Creek watershed (see Figure 3). Unincorporated cities include Cedar Mill and Aloha. 


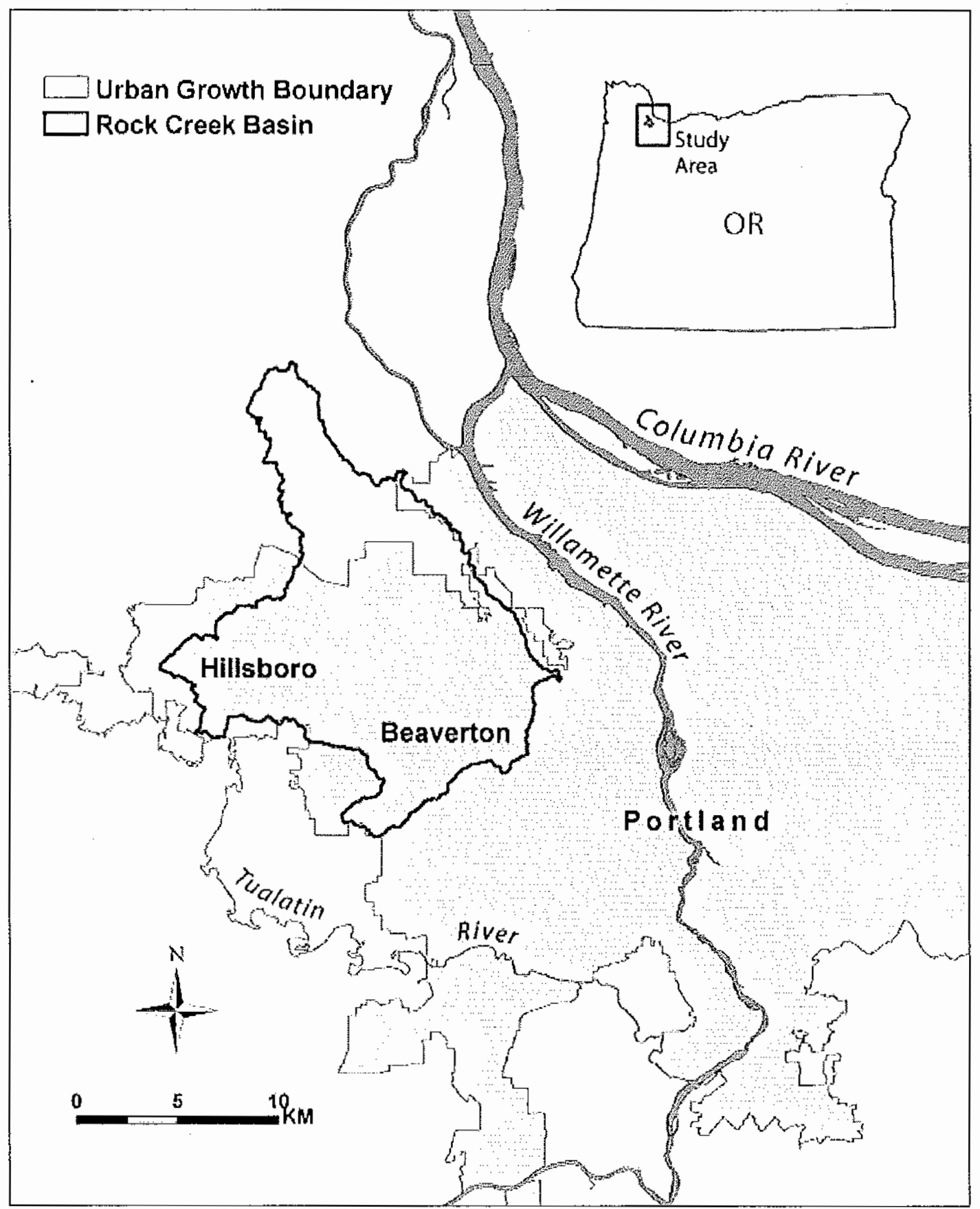

Figure 3: Location of the Rock Creek basin relative to Portland, OR and the surrounding urban growth boundary. 
Washington County has become one of Oregon's fastest growing regions; both Beaverton and Hillsboro have experienced similar rapid urban growth. Beaverton's population has increased by $10.7 \%$ from 83,095 in 2000 to an estimated 84,270 in 2006, and Hillsboro has seen an estimated 20.3\% increase during the same period. This is compared to $12.4 \%$ population growth for Washington County between 2000 and 2006 (Oregon Blue Book 2007). The rapid growth is further illustrated in a comparison of the major land use categories within the Rock Creek watershed for the 1992 and 2001 National Land Cover Datasets developed by the USGS. In 1992 the percentage of urban and agricultural land use was approximately the same at approximately $31 \%$ and $33 \%$ of the watershed area, respectively. Forested land accounted for $28 \%$ of the watershed area. By 2001 there was a significant change in the distribution of land cover. The area of the watershed devoted to agricultural use and forested land was reduced to approximately $13 \%$ and $15 \%$, respectively, while urban land use increased to approximately $60 \%$ of the watershed area (USGS 1992, USGS 2006). Because the population is projected to continue to increase for both Beaverton and Hillsboro, urban land cover will continue to expand throughout the RCB. 


\section{AVSWAT-X MODEL}

\subsection{Description of AVSWAT-X Model}

The ArcView Soil Water Assessment Tool Extension (AVSWAT-X) model, version 2005 , was used in this study. SWAT is a continuous, physically based, semi-distributed hydrology model first created by the U.S. Department of Agriculture (USDA) and the Texas Experimental Station (TES) in the early 1990s as a component of the larger model BASINS (Better Assessment Science Integrating point and Non-point Sources) (Stone et al. 2001, Arnold \& Fohrer 2005). It was created primarily to (1) determine the affects of climate and management on hydrology, (2) measure water quality, and (3) emphasize continuous time simulation (Arnold \& Fohrer 2005). SWAT was designed to simulate long-term water yields and is not accurate for single-event analysis (Neitsch et al. 2005). AVSWAT-X is similar to the previous SWAT models, but is entirely contained in the ArcView 3.x graphical user interface. In this way, watershed delineation, defining land and soil divisions, editing hydrological and management input parameters, running, and calibrating the model is contained in one GIS environment. It also includes tools for automatic sensitivity analysis, calibration, and uncertainty analysis (Di Luzio et al. 2005, Gassman et al. 2007). SWAT's initial creation was to assess changing water supplies and determine nonpoint source pollution within large river basins. This information would assist water resource managers in determining policy impacts on watersheds (Neitsch et 
al. 2005). The model design considers the affects of (1) climate and management, (2) continuous time simulations, and (3) water quality (Arnold \& Fohrer 2005). Because this study is primarily concerned with stream flow, the following model description will focus on aspects of SWAT that are influential in stream flow generation.

SWAT is considered a semi-distributed spatial model (El-Nasr et al. 2005). While some of its initial datasets are introduced in a grid format, the watershed is then first delineated into sub-basins and then further lumped as Hydrologic Response Units (HRUs). HRUs are divisions within watershed sub-basins that are homogeneous with respect to land use, management, and soil attributes. They are considered the total area within a sub-basin made up of one unique combination of these attributes (Neitsch et al. 2002). Within each sub-watershed, all SWAT processes are aggregated at the HRU scale, and there are no interactions among different HRUs within a sub-basin. Runoff is calculated for each HRU and then added together to determine the total discharge from the sub-basin. Final discharge from the main channel basin outlet is the accumulation of sub-basin discharges routed through the river system (El-Nasr et al. 2005). This is calculated using two variations on the kinematic wave approach, including either the variable-rate storage method or the Muskingum method (Gassman et al. 2007). In this way, the model can account for greater differences in land cover and soil processes, thus producing a greater representation of the water balance throughout the watershed 
than a lumped hydrology model, while reducing the large computational time associated with a fully distributed model (Watts 1997, Neitsch et al. 2005).

The simulation of the watershed's hydrological cycle in SWAT is divided into two categories: the land phase and the water or routing phase. The land phase describes the movement of water, nutrients, pesticides, and sediments throughout the sub-watersheds to their main channel. The water, or routing, phase characterizes how water moves through the water channel system (Neitsch et al. 2005). The construction of the SWAT model can be divided into several components: upland components, stream processes, ponds and reservoirs, and water diversions. Upland components include hydrology, weather, soil temperature, erosion and sedimentation, plant growth, nutrients, pesticides, and land and water management. Stream processes include channel sediment routing, channel flood routing and nutrient and pesticide routing and transformation. Ponds and reservoirs components include water balance, sediment settling, routing, and nutrient and pesticide routines. Finally, the water diversions component can simulate withdrawals from the system (Arnold \& Fohrer 2005).

The use of the SWAT model in hydrological analysis is divided into three general components. These include (1) preprocessing or generating topographic and model input parameters at the sub-basin level, (2) input data editing and model simulation and (3) post-processing the model results (Arnold \& Folrer 2005). Because SWAT is a physically based model, data regarding watershed topography, 
soil characteristics, climate, land cover, and management are required inputs. Much of this information is readily available in digital formats from local, regional, or federal government agencies, thus reducing the time spent data gathering. (Di Luzio et al. 2005, Neitsch et al. 2005).

SWAT operates on a daily time step, requiring daily precipitation and maximum and minimum temperature, solar radiation, wind speed, relative humidity, and evaporation as inputs: These datasets can be added as observed data or produced statistically within the weather generator tool. The WxGEN weather generator tool developed by the U.S. Department of Agriculture is included in the SWAT model and can be used to generate new climate data or simulate unavailable climate data (Neitsch et al. 2005). For precipitation distributions throughout the basin, SWAT uses as the default the Markov chain-skewed distribution or the Markov chain-exponential distribution (Neitsch et al. 2005). Outputs from the model can be in annual, monthly, daily, and hourly timescale (Govender \& Everson 2005, Neitsch et al. 2005). The SWAT model uses point estimates (gage stations) to generate weather parameters and assumes spatial uniformity of weather based on these points. Although this does not account for the distributed nature of precipitation, the use of several gage stations can help reduce this limitation (Muleta et al. 2007).

A soil water content water balance equation 'provides the basis for the modeling processes in SWAT: 


$$
S W_{t}=S W_{0}+\sum_{i=1}^{t}\left(R_{\text {day }}-Q_{\text {surf }}-E_{\mathrm{a}}-w_{\text {seep }}-Q_{\mathrm{Bw}}\right)
$$

where $\mathrm{SW}_{\mathrm{t}}$ is the soil water content (final), $\mathrm{SW}_{0}$ is the soil water content (initial) on day $i\left(\mathrm{~mm} \mathrm{H}_{2} \mathrm{O}\right), \mathrm{R}_{\text {day }}$ is precipitation on day $\mathrm{i}\left(\mathrm{mm} \mathrm{H}_{2} \mathrm{O}\right)$, $\mathrm{Q}_{\text {surf }}$ is surface runoff on day $\mathrm{I}\left(\mathrm{mm} \mathrm{H}_{2} \mathrm{O}\right), \mathrm{E}_{\mathrm{a}}$ is evapotranspiration on day $\mathrm{i}\left(\mathrm{mm} \mathrm{H}_{2} \mathrm{O}\right), \mathrm{w}_{\text {seep }}$ is percolation or seepage from soil profile to vadose zone, and $\mathrm{Q}_{\mathrm{gw}}$ is return flow on day $\mathrm{i}(\mathrm{mm}$ $\mathrm{H}_{2} \mathrm{O}$ ). Surface runoff, $Q_{\text {surf, }}$ is calculated either using a modified SCS Curve Number method $(\mathrm{CN})$, moisture condition II or the Green and Ampt Equation. The $\mathrm{CN}$ measurement is updated daily and fluctuates according to soil type, land use, cover, and water content (Stone et al. 2001, Neitsch et al. 2005). Figure 3 shows the procedure used by AVSWAT-X to model runoff. 


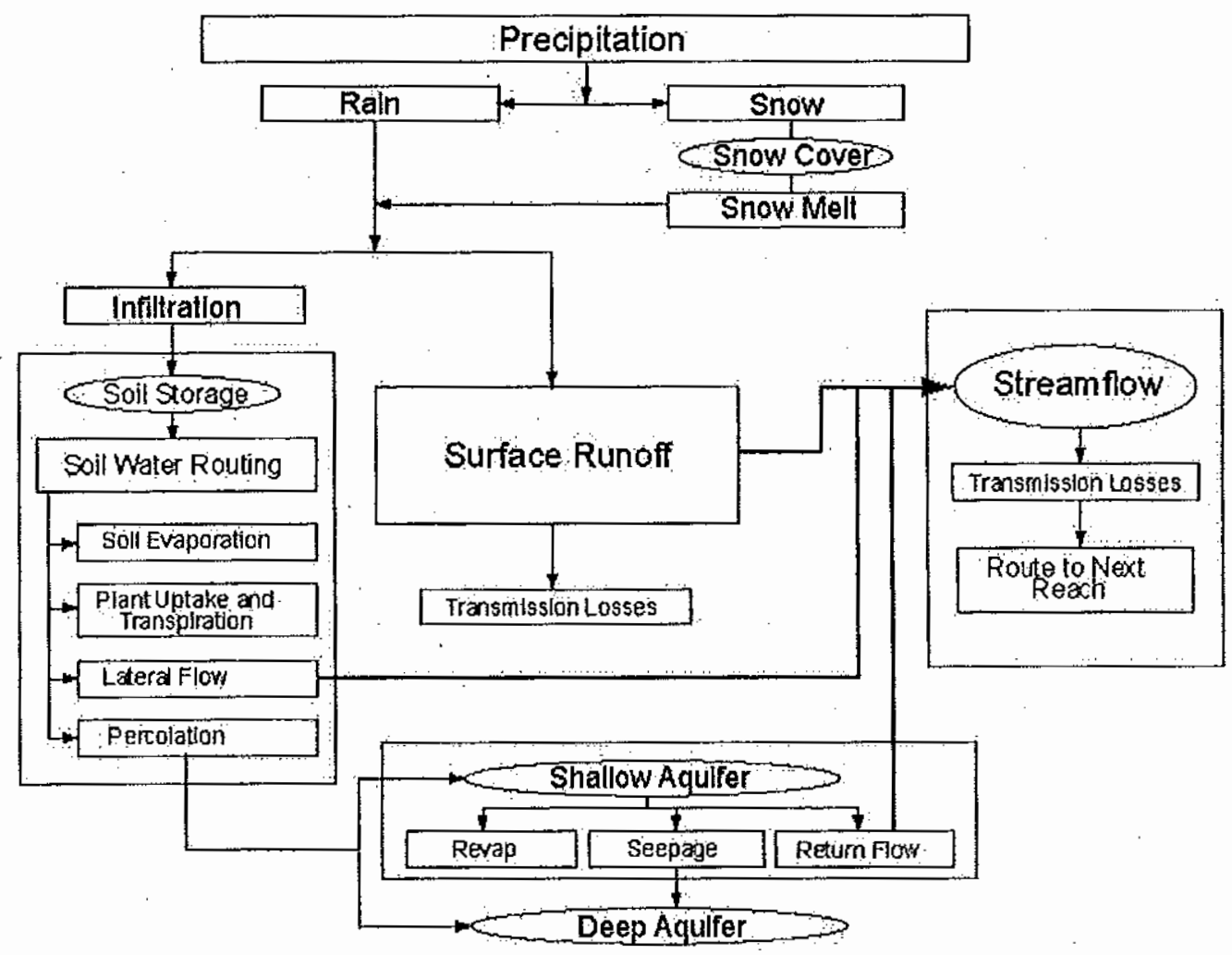

Figure 4: Procedure used by AVSWAT-X to model runoff. Source: Neitsch et al. (2005).

Urbanized runoff from hydraulically connected impervious areas (e.g. transportation) is determined separately from those impervious areas that are hydraulically disconnected or pervious (e.g. residential, low-density). Using the SCS CN method, directly connected impervious areas are always represented by a 98 value, modeled as regions of high runoff and minimal infiltration. For areas with disconnected impervious surfaces, the $\mathrm{CN}$ is determined from a composite equation 
that employs fractions of the HRU that are either impervious (disconnected) or pervious surfaces (Neitsch et al. 2005).

Potential evapotranspiration (PET) is computed in order to estimate the combination of evaporation from soil and transpiration from plants. According to Thornthwaite (1948), potential evapotranspiration is "the rate at which evapotranspiration would occur from a large area uniformly covered with growing vegetation that has access to an unlimited supply of soil water that was not exposed to advection or heat storage effect" (Neitsch et al. 2002, 121) There are three methods available in SWAT for calculating PET: the Penman-Monteith method, the Priestley-Taylor method, or the Hargraves method. The Penman-Monteith method of determining PET is considered the most accurate; however, in order to obtain its highest accuracy, it requires hourly data, which is then summed to obtain daily PET values. Other required data includes solar radiation, air temperature, relative humidity, and wind speed. The Priestly-Taylor method is a simplified version of the equation used in the Penman-Monteith method. It requires only mean daily data for solar radiation, air temperature, and relative humidity to provide reliable daily PET estimates. Because it is the default method used in SWAT and is used in this study, the method's equation is included:

$$
\lambda E_{0}=\alpha_{\text {pet }} \cdot \frac{\Delta}{\Delta+\gamma} \cdot\left(H_{\text {yet }}-G\right)
$$

where $\lambda$ is the latent heat of vaporization $\left(\mathrm{MJ} \mathrm{kg}^{-1}\right), E_{0}$ is the potential 
evapotranspiration $\left(\mathrm{mm} \mathrm{d}^{-1}\right), \alpha_{\text {pet }}$ is a coefficient, $\Delta$ is the slope of the saturation vapor pressure-temperature curve, $\mathrm{de} / \mathrm{dT}\left(\mathrm{kPa}^{\circ} \mathrm{C}^{-1}\right), \gamma$ is the psychrometric constant $\left(\mathrm{kPa}^{\circ} \mathrm{C}^{-1}\right), H_{\text {net }}$ is the net radiation $\left(\mathrm{MJ} \mathrm{m}^{-2} \mathrm{~d}^{-1}\right)$, and $G$ is the heat flux density to the ground $\left(\mathrm{MJ} \mathrm{m}^{-2} \mathrm{~d}^{-1}\right)$. Finally, the Hargraves method was developed through eight years of research at Davis, California and requires air temperature only (Neitsch et al. 2002, Neitsch et al. 2005).

In nature, recharge of groundwater comes from the infiltration of precipitation and can be influenced by surface permeability and topography. Groundwater primarily flows into rivers and lakes, although some amount may contribute to deeper aquifers. In order to model groundwater in the hydrological system, SWAT calculates two aquifers for each sub-basin: the shallow aquifer and the deep aquifer. The shallow aquifer is unconfined and designed to contribute flow to the main channel and tributaries, based on a threshold water depth value. The deep aquifer is confined and is considered to contribute flow outside of the system; therefore, it is not included in water budget calculations (Neitsch et al. 2005).

\subsection{Applications of SWAT in Previous Research}

The SWAT model has been used in numerous studies concerning climate change and/or land cover changes. Although the majority of studies have addressed climate change, the few that have been used for determining the influence of urbanization on water resources will be discussed here as well. This section will 
focus on studies within the previous five years.

Results from climate change impact assessments using SWAT are generally regional in nature; however, there are some discernable trends. The majority of studies project annual decreases in runoff for river basins in Greece (Varanou et al. 2002), Germany (Eckhardt \& Ulbrich 2003, Krysanova et al. 2007), Finland (Bouraoui et al. 2004), and India (Gosain et al. 2006,). Increases in winter flooding are anticipated for the Ali Efenti basin, Greece (Varanou et al. 2002) and the Dill basin, Germany (Eckhardt \& Ulbrich 2003). However, annual runoff for the Mississippi River, USA (Jha et al. 2006) and Luohe River, China (Zhang et al. 2007) is projected to increase. In general, all of the studies anticipate large seasonal and monthly variations in projected runoff. Table 4 summarizes research papers within the previous five years that assess the affect of climate change on stream flow. 


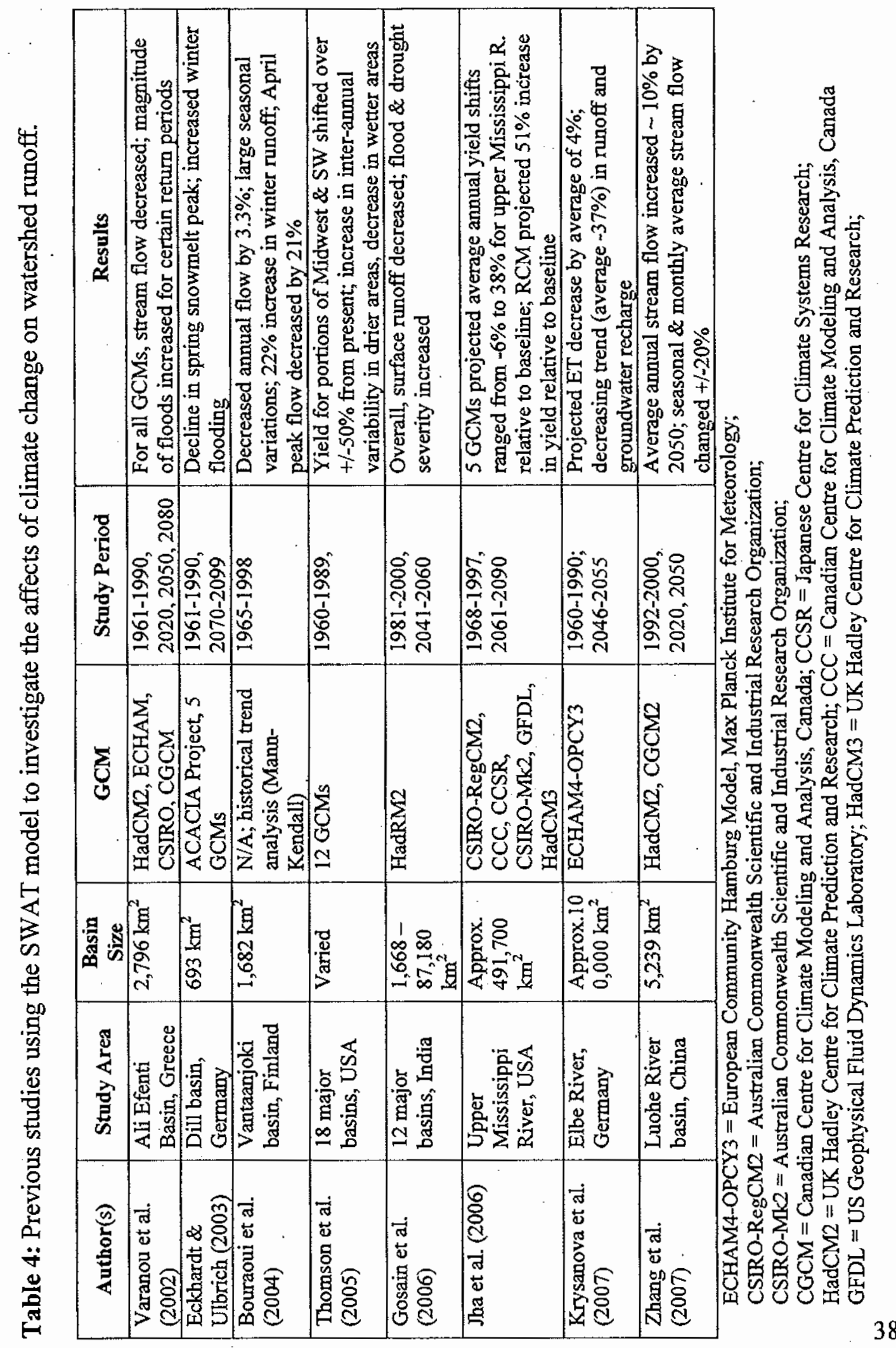


Only two studies were found that used the SWAT model in determining the influence of urbanization on runoff. Using land cover scenarios representing a change in total watershed urbanization from $6 \%$ in 2000 to $70 \%$ in 2020 , Kalin and Hantush (2006) investigated the affects on both groundwater and surface flow. They found that, although groundwater contributions to surface flow would be reduced, actual surface flow would be basically unaffected. Lee and Chung (2007) investigated how increased urbanization would influence runoff in a small, mountainous watershed in the Gyeonggi Province, South Korea during the dry weather season (8-months). They determined that urban land cover had a relatively minor influence on runoff over the 30 -year study period. Table 5 summarizes research papers that assess the influence of urbanization on stream flow.

Table 5: Previous studies using the SWAT model to investigate the affects of urbanization on watershed runoff.

\begin{tabular}{|l|l|l|l|l|}
\hline \multicolumn{1}{|c|}{ Author(s) } & Study Area & \multicolumn{1}{c|}{$\begin{array}{c}\text { Basin } \\
\text { Size }\end{array}$} & $\begin{array}{c}\text { Study } \\
\text { Period }\end{array}$ & \multicolumn{1}{|c|}{ Results } \\
\hline $\begin{array}{l}\text { Kalin and } \\
\text { Hantush } \\
(2006)\end{array}$ & $\begin{array}{l}\text { Pocono Creek, } \\
\text { Pennsylyania, } \\
\text { USA }\end{array}$ & $120 \mathrm{~km}^{2}$ & $\begin{array}{l}2002-2004, \\
2005-2024\end{array}$ & $\begin{array}{l}\text { Urban land cover increase from } \\
6 \%(2000) \text { to } 70 \%(2020) \text { results in } \\
30 \% \text { decline in groundwater } \\
\text { contribution to surface flow, 1.1\% } \\
\text { decrease in surface flow }\end{array}$ \\
\hline $\begin{array}{l}\text { Lee and } \\
\text { Chung } \\
(2007)\end{array}$ & $\begin{array}{l}\text { Gyeonggi } \\
\text { Province, } \\
\text { South Korea }\end{array}$ & $13.42 \mathrm{~km}^{2}$ & $1975-2004$ & $\begin{array}{l}\text { Increased urbanization }(+14 \%) \\
\text { reduced runoff by 3.6\% over the } \\
\text { 30-year period }\end{array}$ \\
\hline
\end{tabular}




\section{DATA AND METHODS}

\subsection{Software}

The hydrological modeling software used in this study was the 2005ArcView Soil Water Assessment Tool Extension (AVSWAT-X) (AVSWAT$\mathrm{X}$ 2006). This is the latest stand-alone version of the SWAT model, and was acquired along with its user's manuals (De Luzio et al. 2002, Neitsch et al. 2002), theoretical documentation (Neitsch et al. 2005), and input/output documentation (Neitsch et al. 2004) from the SWAT website (AVSWAT-X 2006). Software used in conjunction with or in addition to AVSWAT-X in order to complete this study included ESRI's ArcView 3.3 (ESRI 2002) and ArcGIS 9.2 (ESRI 2005).

\subsection{Data Summary}

The data used for the initial model development included a 10-meter Digital Elevation Model, STATSGO soils coverage, daily weather data, landuse/land cover datasets, a basin shapefile, and river gage station data. Table 6 summarizes all datasets used in this study and includes source information. 
Table 6: Datasets included in the Rock Creek hydrological model.

\begin{tabular}{|c|c|c|c|c|}
\hline & Datasets & Format & Resolution & Source \\
\hline \multirow{3}{*}{ Upland } & $\begin{array}{l}\text { Digital Elevation } \\
\text { Model (DEM) }\end{array}$ & Raster & 10 meter & USGS (2004) \\
\hline & Soil Layer (OR) & Shapefile & $\mathrm{N} / \mathrm{A}$ & NRCS (2001) \\
\hline & Watershed boundary & Shapefile & N/A & OGDC (2005) \\
\hline \multirow{2}{*}{ Land Cover } & NLCD, 2001 & Raster & 30 meter & USGS (2006) \\
\hline & Projections, 2040 & Raster & 30 meter & PNW-ERC (2002) \\
\hline \multirow{4}{*}{ Climate } & $\begin{array}{l}\text { Beaverton, historic } \\
\text { climate }\end{array}$ &. $\mathrm{dbf}$ & N/A & OCS (2007) \\
\hline & $\begin{array}{l}\text { Forest Grove, } \\
\text { historic climate }\end{array}$ &. $\mathrm{dbf}$ & N/A & OCS (2007) \\
\hline & $\begin{array}{l}\text { PDX Airport, historic } \\
\text { climate }\end{array}$ & dbf & N/A & OCS (2007) \\
\hline & $\begin{array}{l}\text { Climate Change } \\
\text { scenario, } 2040\end{array}$ & & & Salathe Jr. (2007) \\
\hline \multirow{3}{*}{ Stream } & NHDPlus flowlines & Shapefile & N/A & (NHDPlus 2007) \\
\hline & $\begin{array}{l}\text { Rock Creek, stream } \\
\text { flow }\end{array}$ & dbf & N/A & OWRD (2007) \\
\hline & $\begin{array}{l}\text { Fanno Creek, stream } \\
\text { flow }\end{array}$ &.$d b f$ & N/A & OWRD (2007) \\
\hline
\end{tabular}

\subsection{Land Cover Datasets}

\subsubsection{Current Land Cover}

For representing the current land cover characteristics in the RCB, this research used the National Land Cover Database (NLCD) dataset for 2001, developed by the U.S. Geological Survey (U.S. Geological Survey 2006). The NLCD 2001 is a 30-meter resolution raster dataset that uses a modified version of the Anderson Level II classification system. It was derived from imagery from the Landsat satellite system and processed according to guidelines detailed in Homer et al. (2004). The 2001 land cover dataset will be referred to hereafter as the "baseline" scenario. 


\subsubsection{Projected Land Cover for 2040}

For representing possible future land cover changes in the $\mathrm{RCB}$, this research used three land cover datasets developed by the Pacific Northwest Ecosystem Research Consortium (PNW-ERC 2002). The PNW-ERC is an organization created to conduct research in western Oregon and Washington on the development of community-based decision making. These datasets each represent a different future scenario, based on projected population growth patterns and potential development characteristics throughout the Willamette River basin for each decade between 1990 and 2050. They were constructed with the help of planners, scientists, and community stakeholders within the basin and are defined by five principal processes: urbanization, rural development, agriculture, forestry, and surface water withdrawals (Hulse et al. 2002).

In addition to community support, each of the three future land cover datasets used a 1990 land cover for the Willamette River basin as the baseline. The 1990 land cover representation was developed from Landsat Thematic Mapper (TM) scenes from 1990 and augmented by other information, such as crop statistics and U.S. Census. Population increases by 2050 are estimated to be 3.9 million, double the amount in 1990, and are assumed to be the same for each scenario. A detailed description of the development of these datasets is found in Baker et al. (2004) and Hulse et al. (2002). The three PNW-ERC scenarios used in this study are the Conservation, Development, and Plan Trend scenarios, which will be 
referred to hereafter as the "Compact,"."Sprawl," and "Planned" scenarios, respectively. Further information on the scenario characteristics can be found in Table 7. Table 8 summarizes the land cover types for the baseline and PNW-ERC scenarios as they are found in the RCB.

Table 7: Description of the three land cover scenarios used in this study to simulate land cover projections within the Rock Creek watershed by 2040 (Source: Hulse et al. 2002).

\begin{tabular}{|c|c|c|c|}
\hline & \multicolumn{3}{|c|}{ Scenarios } \\
\hline & Compact & Planned & Sprawl \\
\hline General & $\begin{array}{l}\text { High priority on } \\
\text { ecosystem protection } \\
\text { \& restoration }\end{array}$ & $\begin{array}{l}\text { Recent trends } \\
\text { continue, existing land } \\
\text { use plans are } \\
\text { implemented }\end{array}$ & $\begin{array}{l}\text { Relaxed land use } \\
\text { policies, market- } \\
\text { driven approach to } \\
\text { land development \& } \\
\text { use }\end{array}$ \\
\hline Ur'ban Development & $\begin{array}{l}\text { Emphasizes high- } \\
\text { density development, } \\
\text { UGBs similar to Plan } \\
\text { Trend }\end{array}$ & $\begin{array}{l}\text { Growth contained } \\
\text { within UGBs \& rural } \\
\text { zones, small } \\
\text { expansion of UGBs }\end{array}$ & $\begin{array}{l}\text { Emphasizes lower- } \\
\text { density development, } \\
\text { greater expansion of } \\
\text { UGBs }\end{array}$ \\
\hline Agriculture & $\begin{array}{l}\text { Conversion of some } \\
\text { cropland to natural } \\
\text { vegetation }\end{array}$ & $\begin{array}{l}\text { Minimal change in } \\
\text { agricultural land use }\end{array}$ & $\begin{array}{l}\text { Majority of } \\
\text { development occurs } \\
\text { on Agricultural land }\end{array}$ \\
\hline Forest & $\begin{array}{l}\text { Gradual decrease in } \\
\text { clear-cut areas, } \\
\text { riparian zones on all } \\
\text { streams }\end{array}$ & $\begin{array}{l}\text { Older conifer forests } \\
\text { mainly confined to } \\
\text { federally-owned lands }\end{array}$ & $\begin{array}{l}\text { Increased clear- } \\
\text { cutting \& less stream } \\
\text { protection }\end{array}$ \\
\hline
\end{tabular}




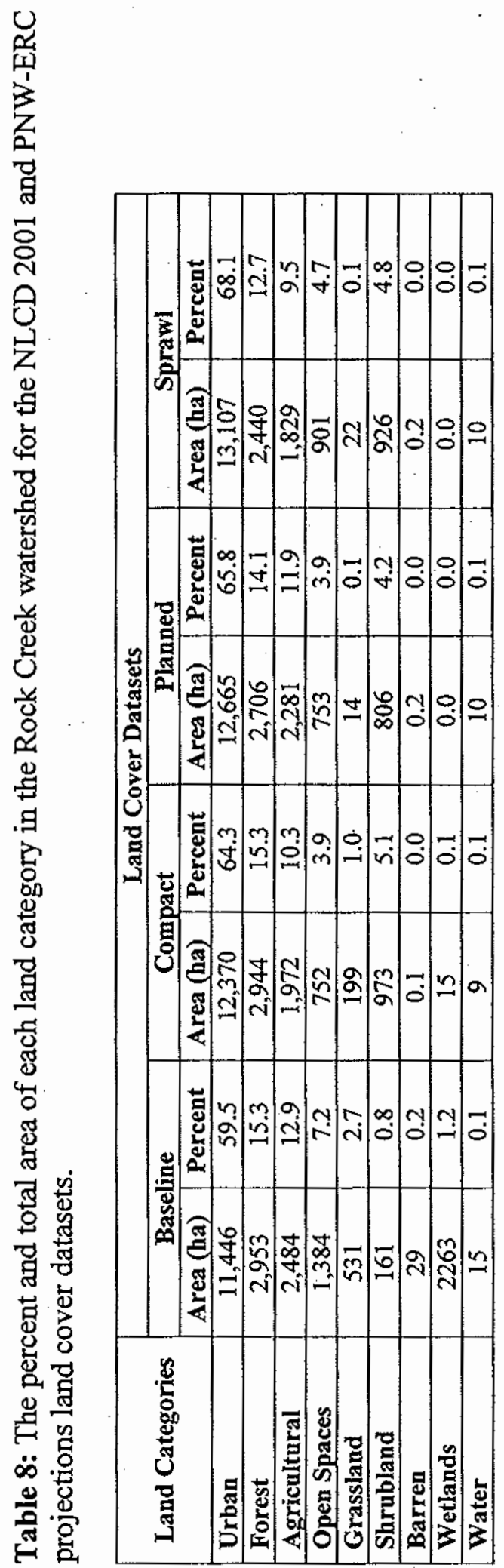


The PNW-ERC land use datasets contained a larger amount of land categories than the NLCD 2001 land cover dataset. Therefore, the PNW-ERC categories were classified in AVSWAT-X to as closely as possible resemble those of the NLCD 2001 dataset. In this way, the land categories for all four datasets would be modeled similarly and could be more accurately compared. Table A.1 in the Appendix shows the original PNERC land cover types, and how they were reclassified into the SWAT classification system.

\subsection{Climate Datasets}

\subsubsection{Historical Climate Data}

Daily precipitation and minimum and maximum temperature data were downloaded from the OCS website for the monitoring stations in Hillsboro (\#353908), Beaverton (\#350595), and Forest Grove (\#352997), and at the PDX Airport (\#356751) (see Table 9).

Table 9: Tualatin River basin climate gage stations (Source: Oregon Climate Service).

\begin{tabular}{|l|l|l|l|l|l|}
\hline Station & Location & Latitude & Longitude & Elevation (m) & Time Series \\
\hline OCS, 352997 & Forest Grove & $45^{\circ} 32^{\prime}$ & $123^{\circ} 06^{\prime}$ & 180 & $1928-2005$ \\
\hline OCS, 350595 & Beaverton & $45^{\circ} 27^{\prime}$ & $122^{\circ} 49^{\prime}$ & 270 & $1972-2005$ \\
\hline OCS, 356751 & PDX Airport & $45^{\circ} 36^{\prime}$ & $122^{\circ} 36^{\prime}$ & 20 & $1941-2007$ \\
\hline OCS, 353908 & Hiflsboro & $45^{\circ} 31^{\prime}$ & $122^{\circ} 59^{\prime}$ & 160 & $1948-2003$ \\
\hline
\end{tabular}

The Beaverton monitoring station was initially chosen as the most viable representation of the Rock Creek climate because it was the closest station to the 
basin and contained the most complete record for the calibration and validation periods. There were no monitoring stations located within the RCB. Later, the Forest Grove monitoring station data was added to attempt to improve the representation of the regional climate, but without influencing the modeled runoff results. As is common with monitoring stations, there were occasional gaps of missing climate data throughout the time series. Data from the PDX Airport and Hillsboro monitoring stations were used to fill in these gaps, as needed.

Different methods were used for filling in gaps of missing climate data from the Beaverton monitoring station's time series. For the precipitation data time series, missing data were estimated based on their correlation to known precipitation values of the same day from the monitoring station in closest proximity. If the closest station had missing data from the same time period, then data from the next nearest station would be used. Because of the distance between the PDX Airport station and the Rock Creek watershed, it was decided to divide the data from the airport station into "dry season" and "wet season" to better estimate the differences in seasonal precipitation. These methods of approximating missing data were important to maintain spatial consistency in climate characteristics.

A similar regression method was also used for estimating missing maximum and/or minimum temperature values, but with a different approach from that of precipitation. For approximating a station's missing values over a number of days a particular month, a regression model for the closest station was created 
based on the previous three years and following three years of the same month, if possible. This regression equation was then used to fill in the missing station's values as they related to the values of the closest station for that time period. For example, missing temperature data in January 2003 for the Beaverton station was filled by correlating it with the January temperature data between 2000 and 2005 from the PDX Airport station. In this way, the temperature trend of that region was a component of the missing value approximation.

\subsubsection{Future Climate Scenarios}

Simulated temperature and precipitation values for 2040 were developed from climate change data downscaled to the $\mathrm{RCB}$ region, acquired from the . Climate Impacts Group (CIG) at the University of Washington (Salathe 2007). These data were developed from the ECHAM5 general circulation model (GCM), the fifth generation of ECHAM models developed by the Max Plank Institute fur Meteorology. This climate model simulated future climate using the A1B emissions scenario, which characterizes a balanced use of fossil fuels in the future. It was included in a group of models employed in the recent IPCC Fourth Assessment Report. Results from the ECHAM5 model were downscaled to a 1/8-degree (15 $\mathrm{km}$ ) resolution grid using statistical downscaling methods described in detail in Salathe et al. (2007). Investigations by Salathe (2005) and Salathe et al. (2007) revealed that the downscaled climate results from ECHAM5 were able to accurately reproduce temperature and precipitation trends for the 20th Century 
$(1970-1999)$ and thus be suited to project realistic future climate changes for the region. As the study found that the different emission scenarios used described similar warming trends to 2050, it was determined that the use of ECHAM5 model driven by the A1B emissions scenario would give a mid-response result and wellrepresent the future climate of the Pacific Northwest (Salathe et al. 2007).

The climate change dataset included modeled daily precipitation and minimum and maximum temperature for two time periods: (1) the years $1970-$ 1999 , used as a baseline and (2) the years $2030-2059$, used to represent average climate for 2040. These datasets correspond with the downscaled grids containing the Beaverton monitoring station. In this way, the climate signal would best represent the mico-climate of the Rock Creek region. In order to prepare the data for use in the AVSWAT-X hydrological model, first, the mean monthly changes in temperature (additive factor) and precipitation (\% change) were calculated between the modeled 20th Century dataset and modeled future dataset (see Table 10). This difference was then applied to daily values of observed climate data over the closest available 30 -year time period $(1973-2002)$ for the corresponding months. For example, the average change in January temperature between the modeled 20th Century and modeled future scenario datasets was applied to each month of January for the observed daily temperature data. The resulting climate datasets would represent observed daily temperature and precipitation for the Beaverton monitoring station with an included mean monthly climate change signal. 
Table 10: Changes in climate for the RCB, according to the ECHAM5 model output.

\begin{tabular}{|lcc|}
\hline & Temperature & Precipitation \\
\hline Month & Add Factor $(0 \mathrm{C})$ & Multiplier \\
\hline January & 2.13 & 1.24 \\
February & 0.98 & 0.80 \\
March & 0.50 & 1.13 \\
April & 0.84 & 1.08 \\
May & 0.44 & 1.14 \\
June & 2.17 & 0.64 \\
July & 1.27 & 1.05 \\
August & 1.28 & 1.34 \\
September & 0.64 & 1.36 \\
October & 1.23 & 0.99 \\
November & 1.21 & 0.97 \\
December & 1.34 & 1.01 \\
\hline Season & & \\
\hline Winter & 1.48 & 1.02 \\
Spring & 0.59 & 1.12 \\
Summer & 1.57 & 1.01 \\
Fall & 1.03 & 1.11 \\
\hline Annual & 1.17 & 1.06 \\
\hline
\end{tabular}

\subsection{Runoff Data Sets}

Observed daily stream flow data for $2001-2005$ came from the Rock

Creek gage station (\#14206450) at Highway 8, the furthest downstream station on Rock Creek. The data was retrieved from the Washington County District-18 Watermaster website (Oregon Water Resources Department 2007) and formatted as required by the AVSWAT-X model. Gaps of missing flow data were estimated using the correlation between Rock Creek flow values and those measured at the Fanno Creek gage station (\#14206950) at Durham Road, near Tigard, OR. Fạnno Creek was chosen because of its proximity to Rock Creek, which would make it 
most likely to experience comparable daily climate and its near-complete dataset. But just as importantly, it is also a highly urbanized sub-basin of the Tualatin Watershed. Because flow data for the Rock Creek gage station at Highway 8 was generally complete only for 2001 through 2005 , this turned out to be the restricting factor in how many years could be used in the calibration and validation of the model.

\subsection{AVSWAT-X Model Set Up}

In order to be able to proceed with any analysis, all of the shapefiles and raster datasets were projected in North American Datum 1983, Universal Transverse Mercator, Zone 10. Datasets were also converted into metric units, where applicable, as this is a requirement of SWAT model inputs. After all of the appropriate datasets were projected, it was necessary to prepare the data for use in the modeling process. First, a shapefile of the Rock Creek watershed boundary was created in ArcGIS 9.2 for use in clipping desired areas. Next, the 10-meter DEM, NHDPlus flowlines, and the NLCD 2001 land use/land cover datasets were brought into ArcGIS 9.2 and clipped using the Rock Creek watershed boundary.

The general steps to developing the AVSWAT hydrology model, in order of completion, include (1) automated delineation of watersheds, (2) land use and soils definitions, (3) HRU definition, (4) definition of weather stations, (5) building initial watershed values, (6) model run, (7) read and map chart results, and (8) calibration and validation (Di Luzio et al. 2005, Neitsch et al. 2002.). 


\subsubsection{Automated Delineation of the RCB}

Because of the unique formatting requirements for spatial datasets used in watershed processing, it was much easier to automatically delineate sub-watersheds from the 10m DEM clipped to the Rock Creek watershed than to introduce premade sub-watershed datasets. The DEM was processed and the sub-watersheds delineated using the model Automated Watershed Delineation tool. Because the watershed was delineated within AVSWAT, the watershed cell size is automatically matched to the DEM resolution. The Rock Creek watershed boundary shapefile was used as a mask in order to "focus" the watershed area within the DEM and reduce GIS processing time. Next, the shapefile of the main stem and tributary flowlines from the NHDPlus dataset was clipped to the watershed and used to "burn" the streams into the DEM. This would more accurately produce the sub-watershed boundaries and stream lines to be used in the model. The detail of the stream network and the size and number of sub-watersheds was also determined by setting the threshold area in the stream definition section of the Automated Watershed Delineation tool. In this study 33 sub-watersheds were created using a 300 ha minimum threshold area (default). All of the generated outlets were included in the final dataset. The Automated Watershed Delineation tool is able to define reservoir locations along the stream network. As there are no reservoirs are located in the Rock Creek watershed, this was unnecessary. 


\subsubsection{Land Use and Soil Definitions.}

In order to determine the land cover and soil distributions and combinations found within each sub-watershed, the Land Use and Soil Definition tool was used. This tool will define a land cover and soil value for each grid within the watershed. First, the land cover raster of the NLCD 2001 Land Cover dataset (clipped to the $\mathrm{RCB}$ ) was introduced and then the land cover/plant/urban codes were manually reclassified using the categories included in AVSWAT. This produces a new layer called SwatLanduse Class. Table A.2 in the Appendix shows the SWAT categories with their corresponding USGS land cover codes. Next, the STATSGO soils layer was introduced and reclassified using the Land Use and Soil Definition tool.

Although soil codes can be assigned manually, a lookup table was created using the 'stmuid' value, which specifies the state STATSGO polygon number and dominant soil phase. Table 11 summarizes the soil types and percent of watershed, as defined by the SWAT model. After the soils lookup table was input into the tool, the soils layer was reclassified using the 'stmuid' reclassification option. This produces a layer called SoilClass. Once the land cover and soil layers were loaded and reclassified, they were then overlaid and the land use and soil definitions process is completed. 
Table 11: The STATSGO soil layer Oregon soil codes and the corresponding 'stmuid' assigned by SWAT for the initial model run.

\begin{tabular}{|c|c|c|c|}
\hline Soil Codes & Stmuid Code & Soil Name & Percent Area \\
\hline OR 081 & 41096 & Bashaw & 0.34 \\
\hline OR 082 & 41098 & Dayton & 46.70 \\
\hline OR 090 & 41081 & Woodbum & 2.08 \\
\hline OR 096 & 41090 & Goble & 9.67 \\
\hline OR 098 & 41082 & Cascade & 42.91 \\
\hline
\end{tabular}

\subsubsection{HRU Definition}

The land cover and soil layers were processed as described above for the purpose of defining the number of hydrologic response units (HRUs) within the RCB. SWAT allows the user to create an HRU that encompasses the entire subbasin, based on the dominant land cover/soil combination, or multiple HRUs within each sub-basin. This study defined multiple HRUs for each sub-basin in order to more accurately capture inter-basin variation (Manguerra and Engle 1998). In this method, a threshold level is set for the amounts of land cover and soil types within each sub-basin to determine the dominant land/soil combinations. This eliminates minor land use/soil combinations in each sub-basin so that only dominant land/soil combinations are modeled. The number of HRUs included in each sub-basin is defined by how many land/soil combinations fall above the established threshold. Multiple HRUs were assigned to each sub-watershed based on the following sensitivities: Land Use at 10 percent, soils at 5 percent. This resulted in $161 \mathrm{HRUs}$ defined within the RCB. Table A.3 in the Appendix summarizes the HRU distribution as defined by the modeling tool. 


\subsubsection{Defining Weather Stations}

The next step is to establish the weather databases that will generate the climate data used in the modeling process. Although it is feasible to generate climate records only using the Weather Simulator included in the model, weather stations located in close proximity to Rock Creek were considered in order to more accurately represent the local climate. Therefore, rainfall and temperature data from the Beaverton monitoring station was used.

Climate inputs to the model are defined using the Weather Simulation Tool included in the SWAT model. This is done within the Weather Data Definitions dialog, found in the Input dropdown menu. In addition to observed temperature and precipitation data, weather simulation data were derived from the US database, which is imbedded within the SWAT model and includes a dataset of weather information from a set of 1,041 weather stations located throughout the United States. Data for solar radiation, wind speed, and relative humidity were all simulated based on the introduced climate data.

\subsubsection{Building Initial Watershed Values}

This is the first step in running the SWAT model. Once the HRUs have been created, the initial watershed input databases must be defined. The input databases are defined based on the watershed delineation and land cover and soil characterizations. There are two methods of building the initial watershed values: (1) use the Write All selection to write them all at once or (2) to individually write 
each input file. Regardless of the method used, the files must be written in the sequence they are presented by the model. Because it was not necessary to adjust any of the individual input files before the initial model run, the Write All selection was chosen. The default value for the Manning's " $n$ " for all the tributary channels $(0.014)$ was chosen for both the sub-basin general input database (.sub) and the main channel input database (.rte). In the management input database (.mgt), plant growth heat units were estimated for each land cover using local climatic data stored in the internal weather generator database.

\subsection{Initial AVSWAT-X Model Run}

Because the initial AVSWAT-X model run would be the basis for the calibration of the model, the period of simulation was set to January 1, 2001 through December 31,2003 . After the printout frequency was changed to monthly outputs, no additional changes were made on the model simulation interface. Rainfall distribution method was kept in the default position (skewed normal) and no edits were made to the Basin Input File or the General Water Quality Input File. The Setup SWAT Run procedure was successful and the simulation finished successfully.

\subsection{Model Calibration and Validation}

The purpose of calibrating and validating a hydrological model is to improve the accuracy of the initial model runoff estimates when compared to the 
observed runoff data. This is accomplished by adjusting selected parameter values until the resulting model output data resembles the observed data as closely as possible (Watts 1997). Because the RCB is subdivided into multiple, explicitly parameterized HRUs, there are a large number of parameters that must be taken into account. Traditionally, model calibration is accomplished by adjusting model parameters manually, using a 'trial-and-error' approach. The accuracy of manually calibrating a hydrology model typically depends upon the modeler's experience and knowledge of the specific model. As a result, it is inherently a subjective process and can take a large amount of time to complete. Although manual calibration provides the user the opportunity to improve his or her understanding of the model, in many instances it is not very repeatable (Watts 1997, Eckhardt \& Arnold 2001, Eckhardt et al. 2005, Muleta \& Nicklow 2005). The 2005 version of AVSWAT-X introduced tools that automated the calibration process by determining an optimal set of parameters and to what extent they should be adjusted. This can eliminate or at lease reduce some of these limitations of manual calibration.

\subsubsection{Automated Sensitivity Analysis}

The first step in the calibration process determined which model parameters were the most influential in matching the modeled estimation of runoff to the observed runoff. To help accomplish this goal, AVSWAT-X provides the Automated Sensitivity Analysis tool. This tool uses a method called the LH-OAT 
sensitivity analysis, which combines a Latin-Hypercube Simulation (LH) with a One-factor-at-a-time (OAT) sensitivity method. First, the sensitivity tool utilizes the LH simulation to perform a random sampling of parameters and ensures that the full range of parameters is included in the analysis. Next, the OAT method integrates local and global sensitivity analysis on all parameters, progressively removing ones less-influential to affecting model output from the analysis. In this way, the parameters most influential to affecting model output are isolated. By using a combination of these two methods, the sensitivity analysis is considered both robust and efficient (van Griensven). The input for the tool includes a .dbf formatted dataset of observed daily runoff that covers the necessary years used in the calibration. Table A.4 in the Appendix shows the 27 different parameters considered in the output of the automated sensitivity analysis tool, a brief description of each one, and their relative ranking in importance.

\subsubsection{Baseflow Estimation}

Estimating the base flow under the stream hydrograph is one important aspect of accurately modeling surface runoff. This has been shown to significantly improve model output and is a suggested step in adjusting the AVSWAT model (Neitsch 2002, SWAT 2007). To determine the average annual ratio of base flow to stream flow for Rock Creek, a base flow filter program was downloaded from the SWAT website (SWAT 2007) and run using the observed runoff dataset over the calibration period. The alpha factor value $(0.136)$ was input as the minimum value 
for the ALPHA_BF model parameter. More information about the base flow filter program and methodology can be found in Arnold et al. (1995) and Arnold \& Allen (1999).

\subsubsection{Model Calibration Methods}

Progress in the calibration of AVSWAT used in the current study involved changing a small number of parameters at a time and comparing the estimated flow outputs before and after the parameter adjustments. The AVSWAT-X Automatic Sensitivity tool results and a review of selected literature were used in order to establish which model parameters were the most influential on stream flow and provide general adjustment guidelines. Determining the correct adjustments to model parameters was done both manually and through the use of the Automated Calibration tool results.

The automated calibration method provided in AVSWAT-X, version 2005 attempts to optimize the model parameter values within each HRU so that the modeled runoff as closely as possible estimates the observed runoff. This results in an output of 'ideal' changes to parameter values, which then must be manually adjusted in the model. There are three ways that parameters can be modified: (1) by value replacement, (2) by addition of absolute change, or (3) by multiplication of a relative change. Although calibration in AVSWAT-X allows parameters to be modified for selected sub-basins or HRUs, parameters were adjusted over the entire Rock Creek watershed in this study. This was because of an inadequate amount of 
data and knowledge necessary to justify adjusting individual HRUs within each sub-watershed.

The method of automatic calibration used in AVSWAT-X utilizes a modified version of the Shuffled Complex Evolution algorithm (SCE-UA), developed by Duan et al. (1992). This is a global search algorithm that has been designed to take into account constraints and interdependencies of model parameters and can calculate the extent to which model parameter values need to be adjusted to reach optimization (Eckhardt et al. 2005, van Griensven Draft). In this way, adjustments can never exceed the predefined parameter ranges, thus maintaining the integrity of parameter characteristics. Although a detailed description of the SCE-UA is beyond the scope of this study, further information and applications can be found in Duan et al. (1992), Eckhardt \& Arnold (2001), Eckhardt et al. (2002), Eckhardt et al. (2005), and van Griensven (Draft).

The automatic calibration results included new values for the Curve Number and ALPHA BF parameters for each HRU. The ESCO parameter had been changed manually during the automatic calibration process. However, calibrated values were not available for Sol_AWC, Ch_K2, and Sol_z, and therefore were manually adjusted within the model using guidelines stated in selected literature (see Table 12). The years 2001 through 2003 were included in the manual calibration, with the year 2000 included to "warm-up" the model. 
Table 12: SWAT model parameters adjusted during the calibration process.

\begin{tabular}{|l|l|l|l|l|l|}
\hline Parameter & \multicolumn{1}{|c|}{ Definition } & Guidelines & \multicolumn{1}{c|}{ Changes } & \multicolumn{1}{c|}{$\begin{array}{c}\text { Initial } \\
\text { Estimates }\end{array}$} & $\begin{array}{c}\text { Calibrated } \\
\text { Values }\end{array}$ \\
\hline CN2 & $\begin{array}{l}\text { Curve Number for } \\
\text { Moisture condition } \\
\text { II }\end{array}$ & $+1-25 \%^{*}$ & $\begin{array}{l}-25 \% \text { to all } \\
\text { values }\end{array}$ & $70.0-92.42$ & $52.5-70.2$ \\
\hline ESCO $^{+}$ & $\begin{array}{l}\text { Soil Evaporation } \\
\text { Compensation } \\
\text { Factor }\end{array}$ & $0.00-1.00$ & $\begin{array}{l}-.85 \text { to initial } \\
\text { value }\end{array}$ & 0.95 & 0.10 \\
\hline SOL_AWC & $\begin{array}{l}\text { Soil Available } \\
\text { Water Capacity } \\
\text { (mm) }\end{array}$ & $0.00-1.00^{*}$ & $\begin{array}{l}+0.20 \text { to all } \\
\text { values }\end{array}$ & $\begin{array}{l}\text { Varies with } \\
\text { soil type }\end{array}$ & $\begin{array}{l}\text { Varies with } \\
\text { soil type }\end{array}$ \\
\hline $\begin{array}{l}\text { ALPHA_BF } \\
+\end{array}$ & $\begin{array}{l}\text { Baseflow Alpha } \\
\text { Factor (days) }\end{array}$ & $0.00-1.00^{*}$ & $\begin{array}{l}0.156 \text { for all } \\
\text { values }\end{array}$ & 0.048 & 0.156 \\
\hline Sol_z ${ }^{(3)}$ & $\begin{array}{l}\text { Depth from soil } \\
\text { surface to bottom } \\
\text { of layer (m) }\end{array}$ & $0-30^{*}$ & $\begin{array}{l}+30 \text { to all } \\
\text { values }\end{array}$ & $\begin{array}{l}\text { Varies with } \\
\text { soil type }\end{array}$ & $\begin{array}{l}\text { Varies with } \\
\text { soil type }\end{array}$ \\
\hline CH_K2 ${ }^{+}$ & $\begin{array}{l}\text { Channel hydraulic } \\
\text { conductivity }\end{array}$ & $0-150^{*}$ & $\begin{array}{l}150 \text { for all } \\
\text { values }\end{array}$ & 0.00 & 150 \\
\hline
\end{tabular}

${ }^{*}$ SWAT auto-calibration tool default setting

(a) Sensitivity analysis provided reference

${ }^{+}$Neitsch et al. (2002) and Benaman et al. (2005) provided references

\subsubsection{Model Validation Methods}

Traditionally, once the calibration process is completed, the calibrated model is tested using a different time-series from the original runoff monitoring stations as input data. This establishes if the model can now accurately estimate output for periods other than those for which it was adjusted (Benaman, et al. 2005, Lin and Radcliffe 2006). In order to validate the Rock Creek model, the years 2004 through 2005 were included in the manual calibration, with the year 2003 included to "warm-up" the model. 


\subsubsection{Statistical Measures of Model Accuracy}

This study employed two methods to statistically test the accuracy of the calibrated runoff output. The most popular statistical measures used for model calibration and validation are the regression coefficient of determination $\left(R^{2}\right)$ and the Nash-Sutcliffe model efficiency (NSE) coefficient (E) (Gassman et al. 2007). For this reason, both methods were included in this study. Although the use of correlation statistics has been questioned as to their appropriateness in evaluating the goodness-to-fit of model simulations, it has had widespread use in past studies (Lagates and McCabe Jr. 1999, Eckhardt and Arnold 2001, Gassman et al. 2007). The $\mathrm{R}^{2}$ value is a measure of how well the regression line representing the modeled versus the observed runoff comes close to a perfect match. It is measured on a scale of between 0 (no correlation) and 1 (observed equals modeled) (Gassman et al. 2007). Legates and McCabe (1999) determined that the Nash-Sutcliffe (E) model is one of the more accurate goodness-to-fit measures available. The $\mathrm{E}$ value is a measure of how well the modeled versus observed runoff line matches a regression line with a slope equaled to 1 . It is measured on a scale of $-\infty$ to 1 , where a value less than zero indicates the mean of the observed is a better predictor when compared to the modeled output and a value of 1 means a perfect fit (Gassman et al. 2007). At this time, there is no agreed upon standard for assessing model accuracy using these statistical tools (Santhi et al. 2001). 


\subsection{Modeling Changes in Land Cover and Climate for 2040}

In order to determine the affect of climate change and land cover change on the runoff from the RCB, eight different model scenarios were created. For representing the contemporary condition in land cover and climate, a model was created that used the NLCD2001 dataset combined with the daily temperature and precipitation data from 1973 to 2002 . This model was used as a baseline for the purposes of comparing contemporary runoff with that of the land cover and climate change models. Next, three models were created that would isolate the influences that increases in urbanization and either no change or decreases in agricultural and forested land would have on runoff in the RCB. These models used one of the three PNW-ERC land cover change scenarios for 2040 combined with the contemporary daily temperature and precipitation data. For determining the affect of climate change on the runoff of contemporary land cover conditions, one model was then created using the Baseline land cover dataset combined with the climate change scenario dataset for 2030 to 2059 . The runoff result from this model will be able to isolate the influence of climate changes on current land cover but also acted as a baseline to compare results from the combined affect of the climate change and land cover scenarios. Finally, three models were created that included the climate change scenario dataset for 2030 to 2059 combined with one of the three PNWERC land cover change scenarios for 2040. Parameter adjustments derived from the calibration/validation process (section 6.8.3) were introduced to each of the 
models. The runoff results from this model set would describe how the different combination of land cover and climate changes could possibly amplify or increasingly alter future runoff changes.

\subsection{Methods for Evaluating Changes in RCB Runoff}

The primary method used in this study for determining the affect of land cover and climate changes on the runoff of the RCB was to analyze mean runoff depths from Rock Creek at the monthly, seasonal, and annual scales. Mean runoff depth is the water depth covering the study basin if all of the mean runoff produced during the specific time period were distributed evenly over the basin area. It has been used as an indicator of change in numerous land cover and climate impact studies, including Grove et al. (2001), Christensen et al. (2005), Tang et al. (2005), Olivia and Defee (2007), and Thodsen (2007). In an attempt to establish possible reasons for any runoff modifications, this study also analyzed the evapotranspiration (ET) volumes modeled by each scenario. Changes in ET rates can affect the amount of precipitation contributing to runoff, particularly between the warmer months of May and September, by reducing soil moisture retention, for example. 


\section{RESULTS}

\subsection{Model Calibration and Validation Results}

The statistical test results from the initial model run show that, prior to calibration, AVSWAT-X provides a mixed representation of mean monthly flow from Rock Creek between 2001 and 2003, when compared to observed flow (Table 13).

Table 13: Results of the calibration based on mean monthly runoff between 2001 and 2005.

\begin{tabular}{|l|c|c|c|}
\hline & Observed & Calibration (01-03) & Validation (04-05) \\
\hline Model efficiency $(\mathrm{E})^{*}$ & -0.871 & 0.89 & 0.60 \\
\hline $\begin{array}{l}\text { Coefficient of } \\
\text { Determination }\left(\mathrm{R}^{2}\right)\end{array}$ & 0.79 & 0.90 & 0.66 \\
\hline
\end{tabular}

*Nash and Sutcliffe (1970)

While the $\mathrm{R}^{2}$ value shows a reasonable correlation between the modeled and observed flow, the Nash-Sutcliffe results indicate an unsuitable measure of model efficiency. Further examination reveals that the modeled flow produces exaggerated winter peaks, particularly for November and December, while slightly overestimating spring runoff (Figure 4). 


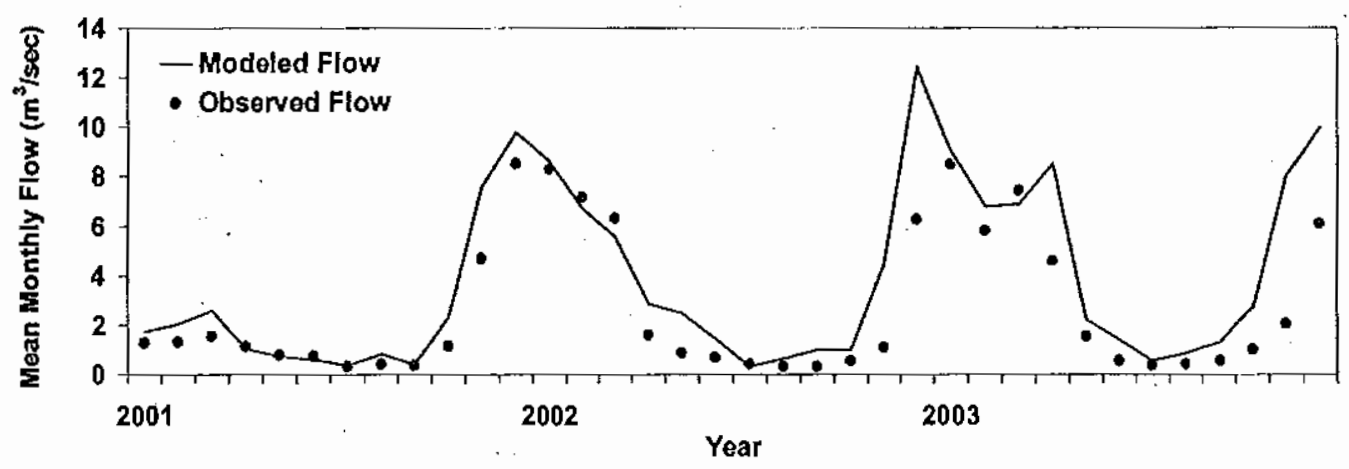

Figure 5: Comparison of flow modeled by the initial AVSWAT-X run and observed flow for $2001-2003$ at the Rock Creek stream flow monitoring station, Highway 8.

Runoff results from the calibrated model show a large improvement in both statistical test results, indicating higher model performance. Likewise, modeled runoff more closely resembles that of the observed flow; however, winter peaks are now slightly underestimated and spring flow remains higher than observed (Figure $5)$.

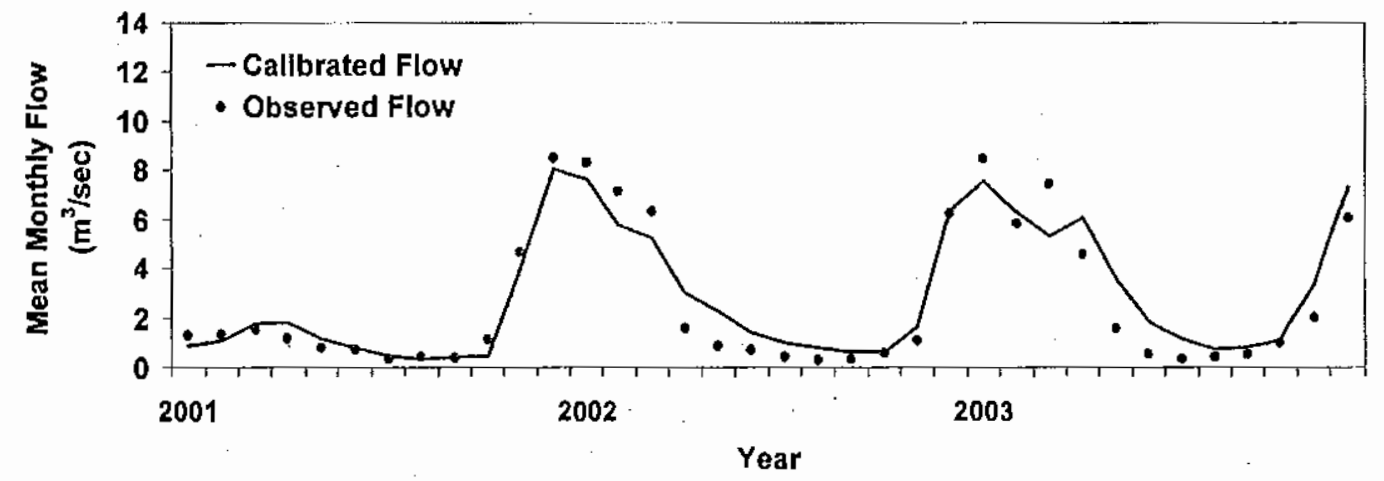

Figure 6: Comparison of calibrated flow and observed flow for 2001 2003 at the Rock Creek stream flow monitoring station, Highway 8. 
An examination of the validation results for $2004-2005$ shows that the winter peak of runoff is generally overestimated by the calibrated flow when compared to observed flow (Figure 6). Statistical test results also indicate that the model is less efficient at reproducing mean monthly runoff from time periods other than those of the calibration period. Both the Nash-Sutcliffe and R2 values signify a reasonable reproduction of observed flow. However, 2004 and 2005 experienced unusually low precipitation during the winter, which may have affected the validation results.

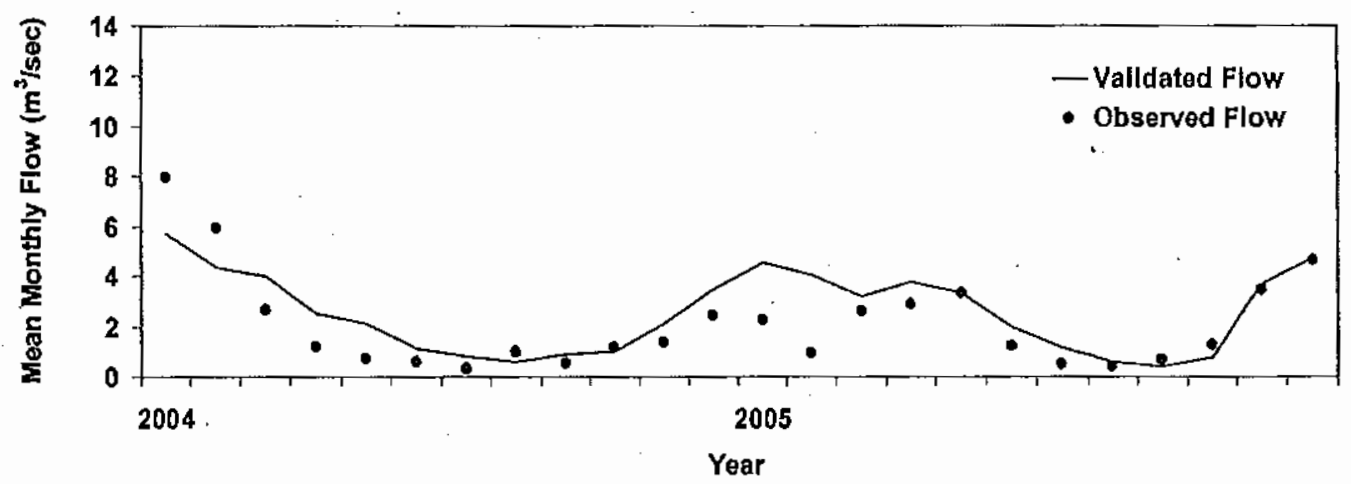

Figure 7: Comparison of validated flow and observed flow at the Rock Creek stream flow monitoring station, Highway 8.

\subsection{Modeled Changes to Climate for $2030-2059$}

Results from the AVSWAT-X model indicate that, under the downscaling results of the ECHAM5 general circulation model run, the mean annual volume of precipitation falling over the Rock Creek watershed will change from $97.2 \mathrm{~cm}$ between 1973 and 2002 to $99.1 \mathrm{~cm}$ between 2030 and 2059, a 2.0\% increase. 
However, there is considerable variation in precipitation at the monthly and seasonal scale. With the exception of the summer months, all of the seasons will experience an increase in precipitation (Figure 7).

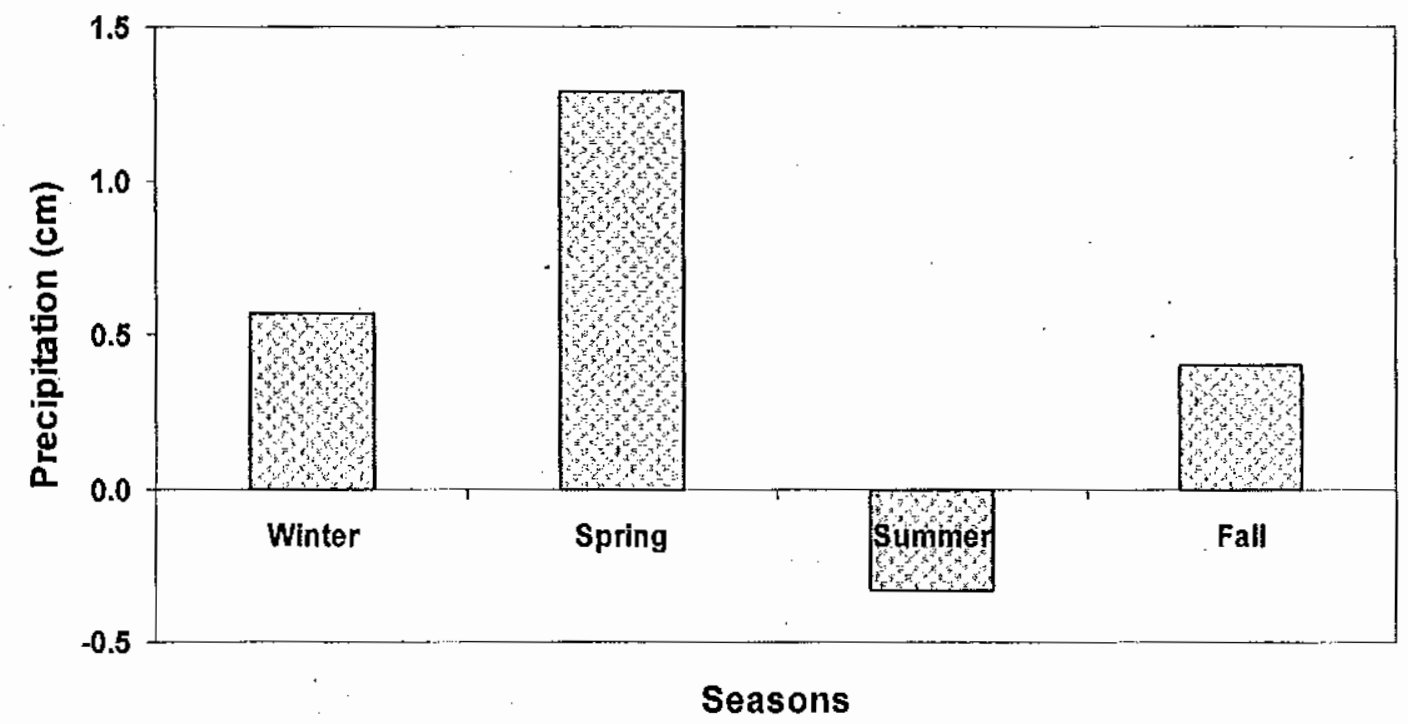

Figure 8: Simulated absolute changes in seasonal precipitation between the baseline climate (1973 - 2002) and the climate change scenario (2030 2059).

Spring will experience the most significant increase, as March, April, and May all saw positive results. This internal seasonal similarity was the exception, because there were both increases and decreases in precipitation changes within winter, summer, and fall months. Absolute change in mean precipitation from the baseline is the most variable in the winter months (Figure 8), containing the month with the largest increase (January, $+11.5 \%)$ and decrease (February, $-10.5 \%$ ). 


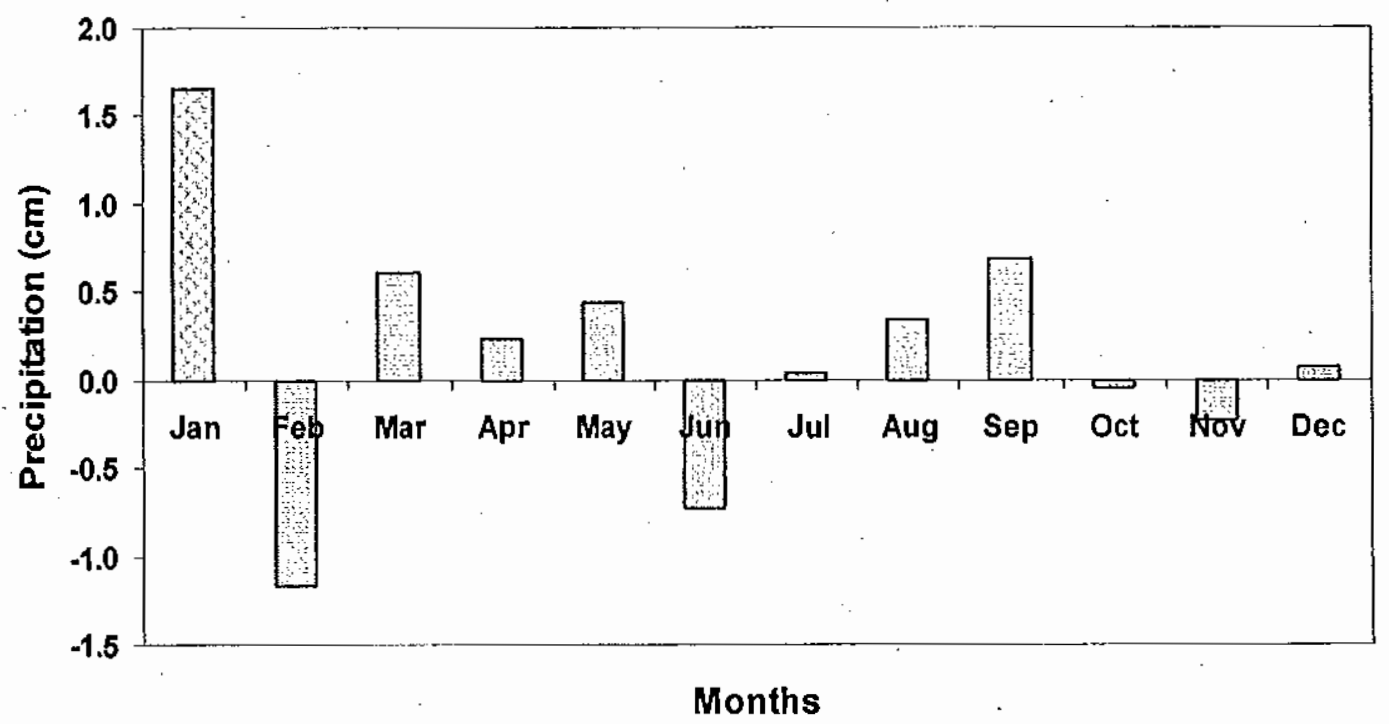

Figure 9: Simulated absolute changes in monthly precipitation between the baseline climate (1973 - 2002) and the climate change scenario (20302059).

\subsection{Runoff Response to Land Cover and Climate Change Scenarios}

\subsubsection{Runoff Response to Land Cover Change}

Analysis of the three PNW-ERC land cover scenarios used in this study show that by the year 2040, urban land use will encompass between 64.3 and $68.1 \%$ of the RCB. The development scenario exhibits the largest percent increase in urban area (14.5\%), while the conservation scenario shows the smallest percent increase $(8.07 \%)$. However, the Compact scenario contains the largest area in highdensity urban land use, while the Sprawl scenario contains the largest low-density residential land use. This indicates that, even though the Sprawl scenario has more urban land, it is more distributed throughout the basin, while the urbanization 
within the Compact scenario is much more concentrated. The Planned scenario characteristics generally fall between the two other scenarios (medium); however, it has a slightly closer resemblance to the conservation scenario. Figures 9,10 , and 11 are maps of the urban land cover showing areas along US Highway 26 that experience the greatest noticeable changes in urban land cover for the 2040 Compact, Planned, and Sprawl scenarios, respectively. A more detailed examination shows that overall, the most expansion will occur with high-density residential land use, with an increase from $5.9 \%$ in 2001 to between 12.0 and $12.4 \%$ in 2040, and low-density residential land use, with an increase from $30.0 \%$ in 2001 to between 35.3 and $43.1 \%$ in 2040 . According to the SWAT Theoretical Documentation Neitsch et al. (2005), high-density and low-density residential areas contain an average of 60 and $20 \%$ impervious surfaces and an average of 44 and $17 \%$ connected impervious surfaces, respectively. For the RCB, projected urbanization for 2040 marks a significant increase in both factors, which could contribute to changes in runoff characteristics. 


\section{Urban Land Cover Types}

Low-density Residential

Medium-density Residential

High-density Residential, Commercial Roads
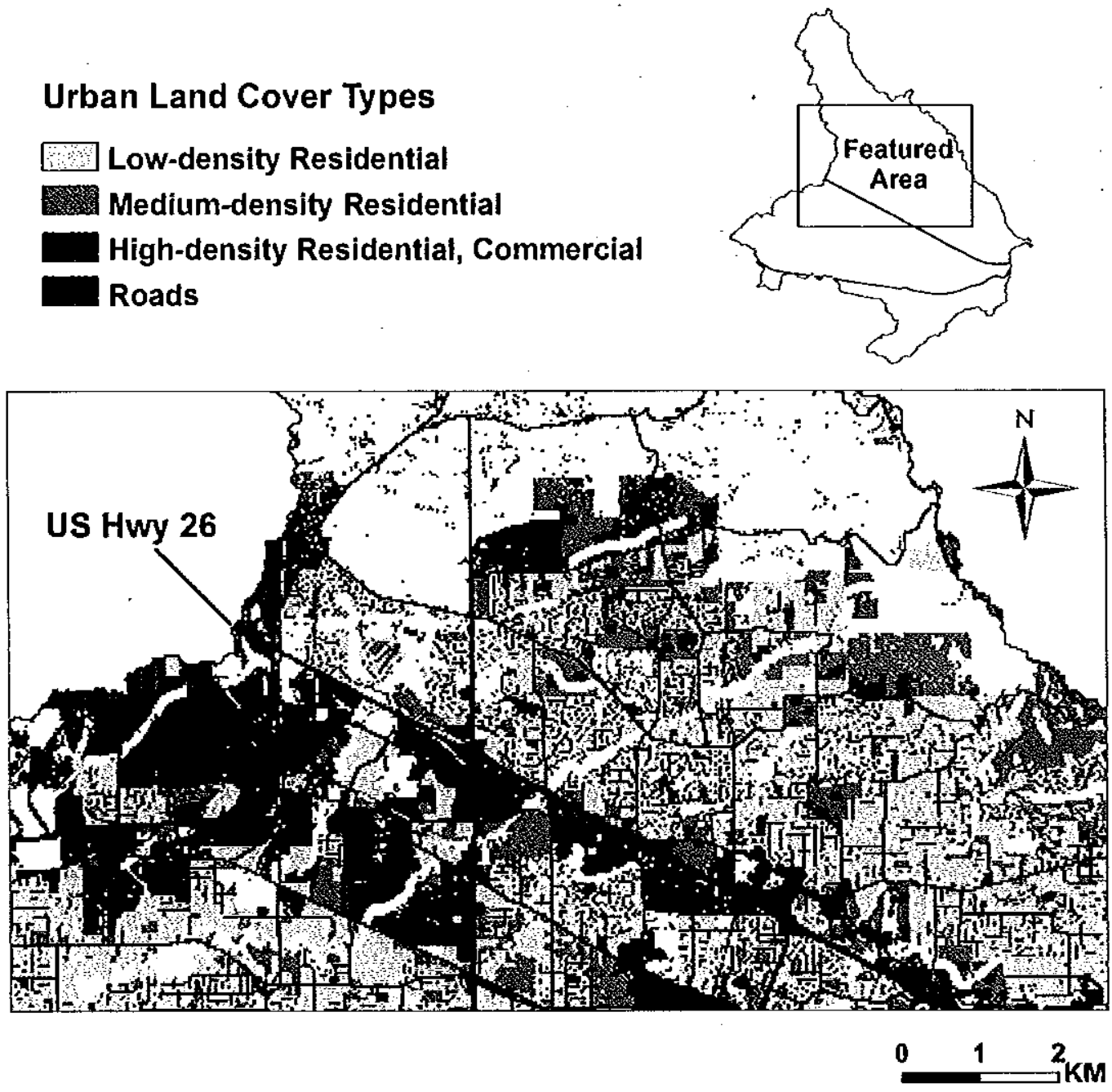

Figure 10: Map showing the urban development within the RCB (near NW $185^{\text {th }}$ Avenue) as modeled by the Compact land-cover scenario for 2040 (Source: PNW-ERC). 


\section{Urban Land Cover Types}

Cow-density Residential

Medium-density Residential

High-density Residential, Commercial

Roads
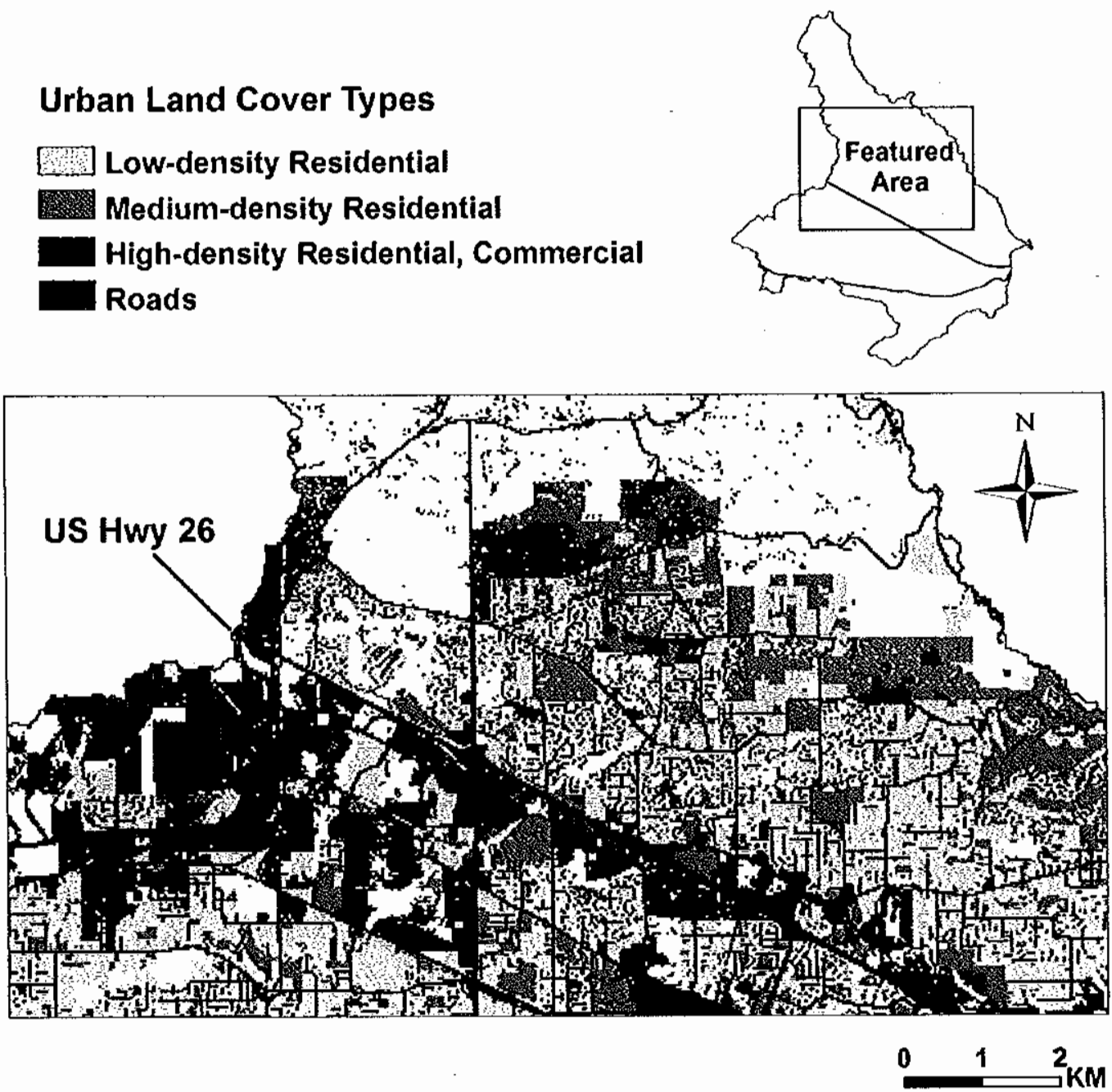

Figure 11: Map showing the urban development within the RCB (near NW $185^{\text {th }}$ Avenue) as modeled by the Planned land-cover scenario for 2040 (Source: PNW-ERC). 
Urban Land Cover Types

Low-density Residential

Medium-density Residential

High-density Residential, Commercial

Roads
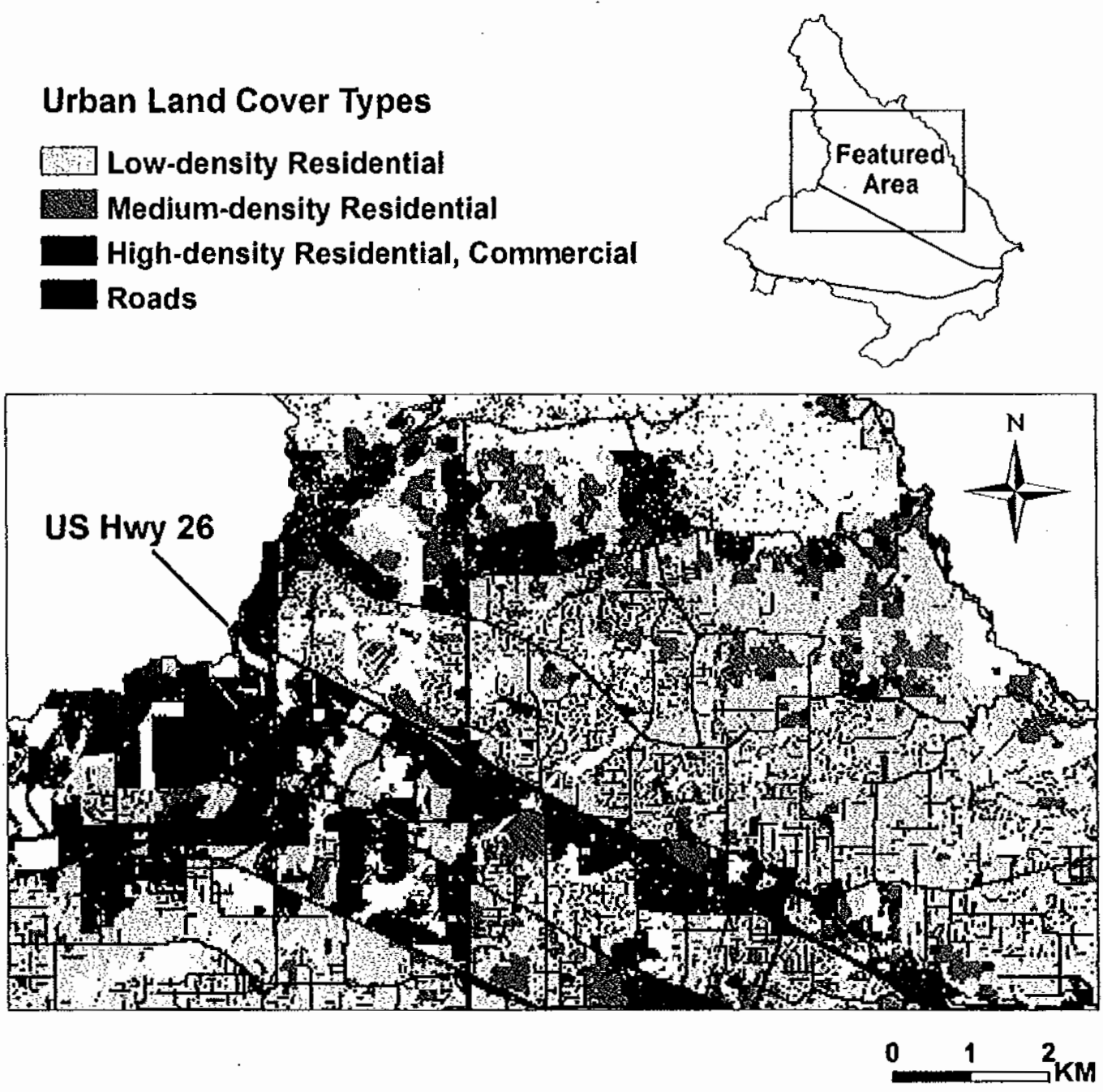

Figure 12: Map showing the urban development within RCB (near NW $185^{\text {th }}$ Avenue) as modeled by the Sprawl scenario for 2040 (Source: PNWERC).

Model results indicate that an expansion of urban land use will result in an increase in mean annual runoff depths over the entire watershed from $57.28 \mathrm{~cm}$ in 2001 to between 58.60 and $58.69 \mathrm{~cm}$ by 2040 , a 2.3 to $2.5 \%$ increase, respectively (Table 14). Results also show that an annual reduction in ET will occur for each 
of the land cover scenarios, with the Sprawl scenario experiencing the largest decrease (see Table 15).

Table 14: Modeled mean total annual runoff depths produced by the baseline scenario and each of the PNW-ERC land change scenarios for 2040 with contemporary climate.

\begin{tabular}{|l|c|c|}
\hline Scenario & Runoff (cm) & \% Change From Baseline \\
\hline Baseline & 57.282 & \\
Compact & 58.642 & 2.37 \\
Sprawl & 58.695 & 2.47 \\
Planned & 58.601 & 2.30 \\
\hline
\end{tabular}

Trends in seasonal runoff changes revealed an increase in absolute change in runoff depth of between $0.03 \mathrm{~cm}$ to $1.47 \mathrm{~cm}$ for all but the spring months (March, April, and May), which exhibited slight decreases (see Figures 12 and 13).

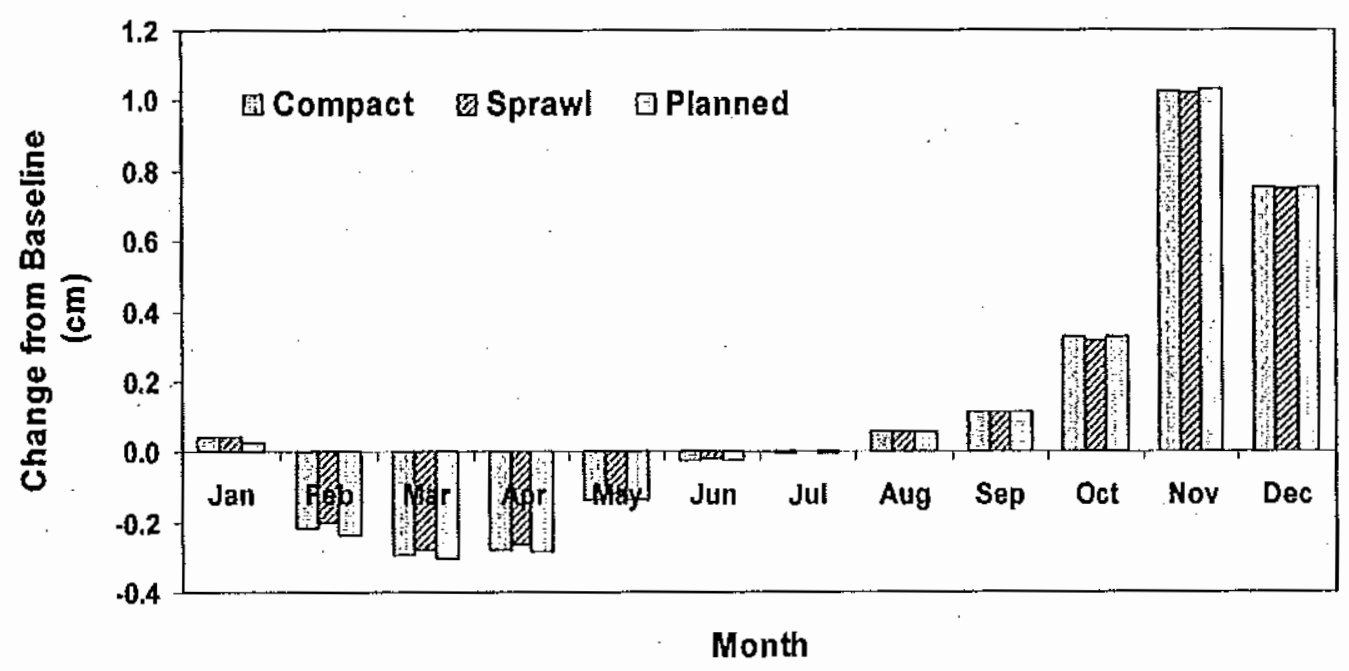

Figure 13: Modeled absolute changes in mean monthly runoff depths for the RCB for each of the PNW-ERC land change scenarios with contemporary climate, when compared to the baseline scenario. 


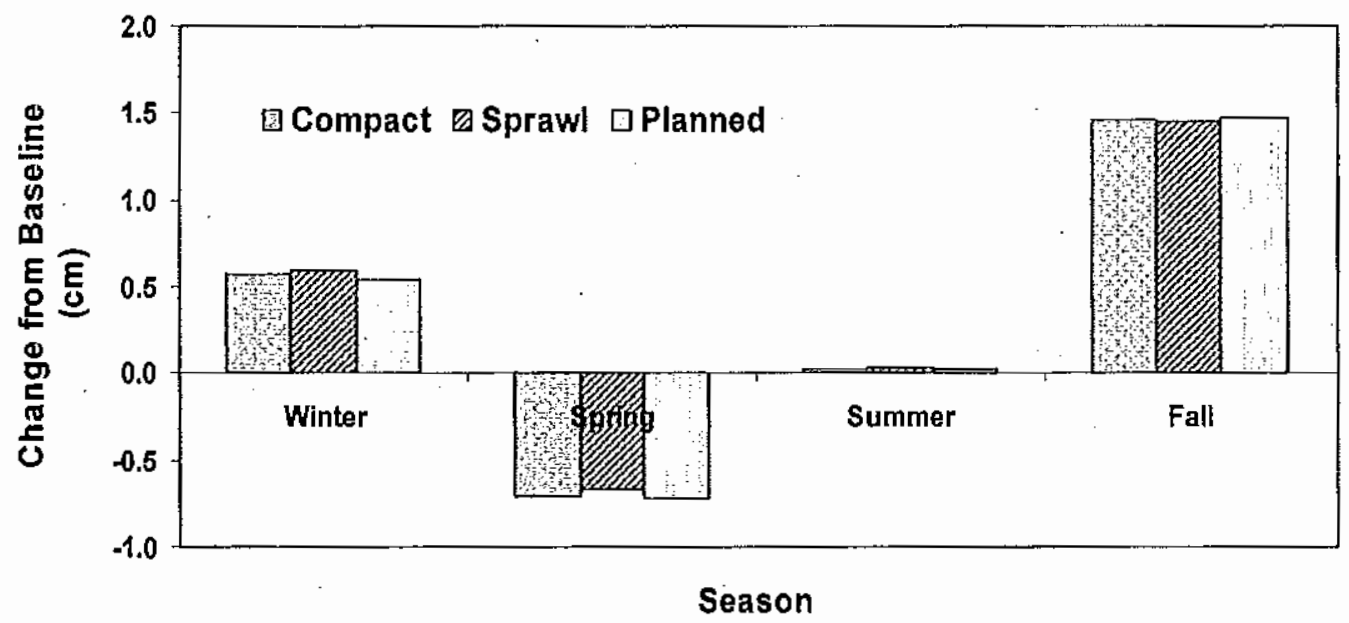

Figure 14: Modeled absolute changes in mean seasonal runoff depths for the RCB for each of the PNW-ERC land change scenarios with contemporary climate, when compared to the baseline scenario.

In fact, at the monthly scale, decreases in the absolute change in runoff depth started during the month of February and extended through to June. Overall, the largest increase occurred in the fall season, particularly during the month of November, beginning month of the wet season. ET results at the seasonal scale show a significant decrease during the summer months (see Figure 14) particularly in the months of July and August, but also to a lesser extent in June and September (see Figure 15). 


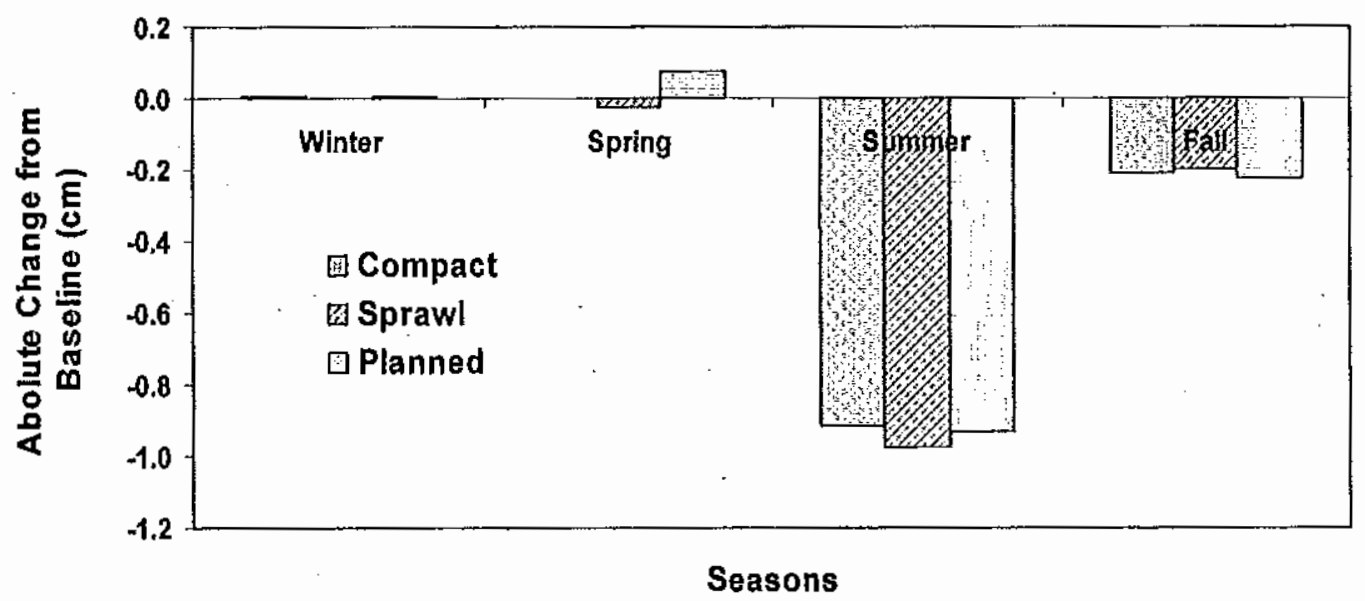

Figure 15: Modeled absolute changes from the baseline scenario in mean seasonal ET for the PNW-ERC land cover scenarios.

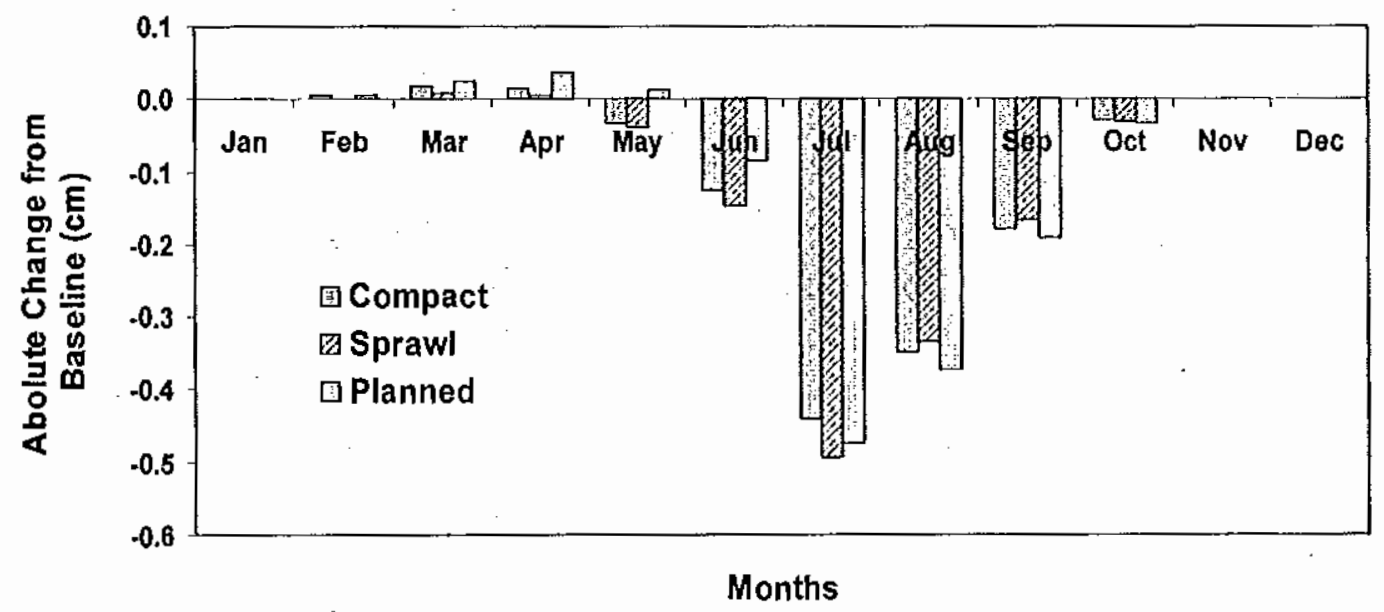

Figure 16: Modeled absolute changes from the baseline scenario in mean monthly ET for the PNW-ERC land cover scenarios. 
In a comparison between the PNW-ERC scenario model results, the runoff values were generally similar. The Sprawl scenario shows the highest increase in absolute change from the baseline in annual runoff depth $(1.41 \mathrm{~cm})$, followed by the Compact scenario $(1.36 \mathrm{~cm})$ and finally the Planned scenario $(1.32 \mathrm{~cm})$. Absolute changes in ET followed a similar pattern, with the Sprawl scenario experiencing the greatest overall summer reductions, followed by the Compact and finally, the Planned scenario (see Table 15).

Table 15: Modeled mean annual ET volumes in the RCB for the baseline scenario and each of the PNW-ERC land scenarios.

\begin{tabular}{|l|c|c|}
\hline \multicolumn{1}{|c|}{ Scenario } & ET (cm) & \% Change From Baseline \\
\hline Baseline & 37.465 & \\
Compact & 36.345 & -2.990 \\
Sprawl & 36.266 & -3.201 \\
Planned & 36.390 & -2.871 \\
\hline
\end{tabular}

\subsubsection{Runoff Response to Climate Change}

Model results show that there are minimal changes in mean monthly runoff depths during the summer and fall months (Figure 16); however, January has the highest increase in runoff volume $(+12.5 \%)$, which results in winter the highest seasonal increase, despite the decrease in Fèbruary runoff. Spring seasonal runoff increases were only slightly smaller than during the winter, but the distribution was more uniform throughout the months of the season. 


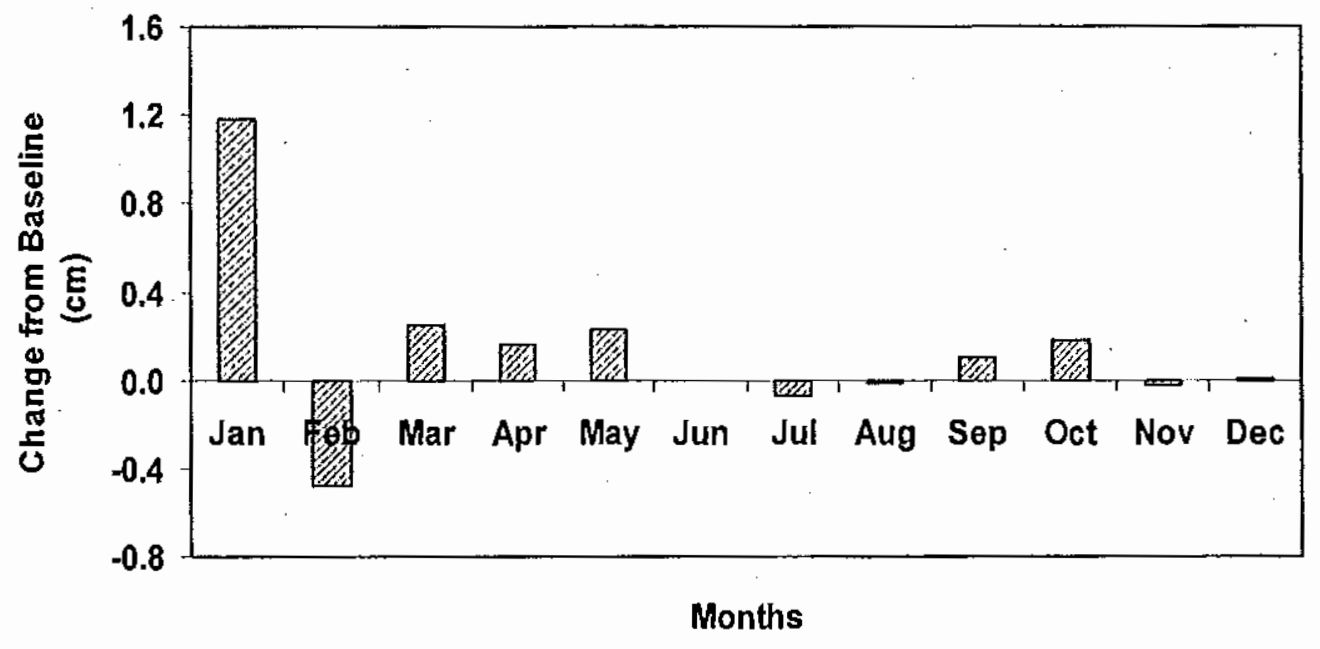

Figure 17: Modeled absolute changes in mean monthly runoff depths for the RCB for the modeled baseline climate change scenario compared to the modeled baseline scenario.

Summer reveals a slight reduction in runoff and fall a slight increase (see Figure 17). Mean ET results show that the highest absolute increase occurs in June $(0.27$ $\mathrm{cm})$, followed by July $(0.15 \mathrm{~cm})$, giving the summer season the highest increase overall (see Figure 18). The largest reduction in ET takes place in September (see Figure 19). At the yearly time scale, results show an increase in total annual runoff volume (Table 16) and ET (Table 17) throughout the basin resulting from climate change. 


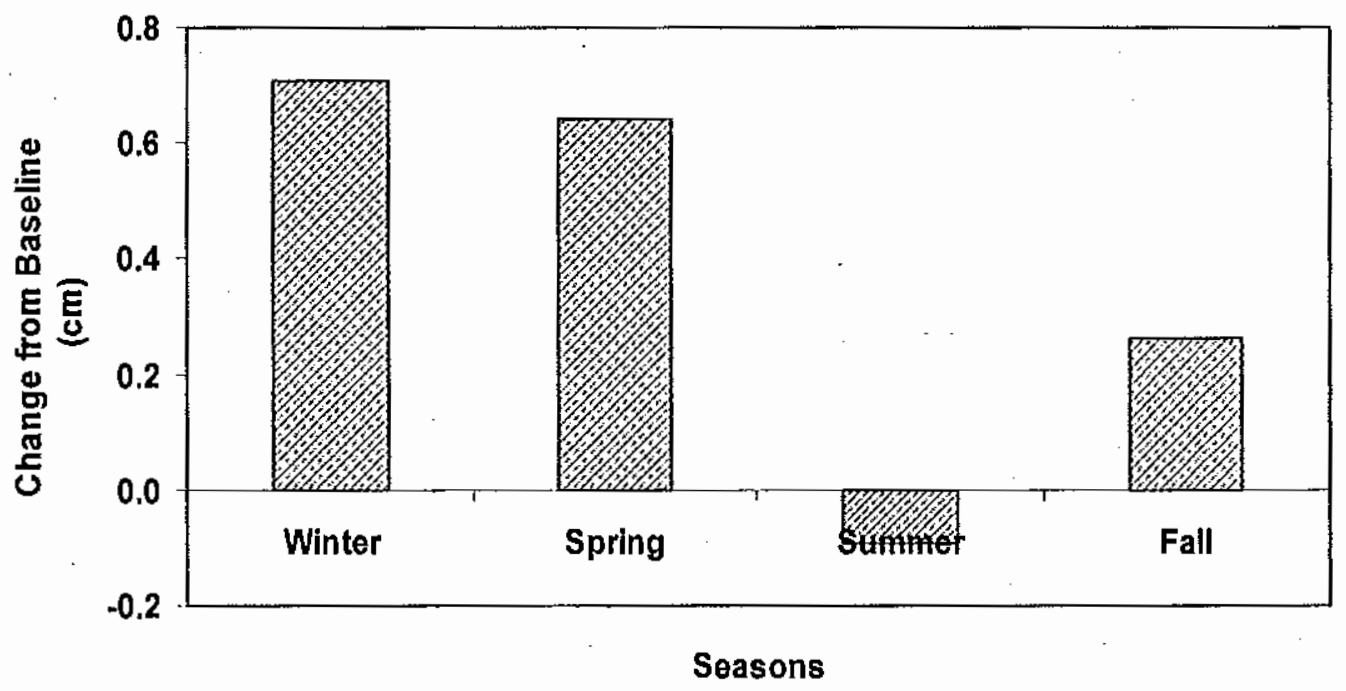

Figure 18: Modeled absolute changes in mean seasonal runoff depths for the RCB for the modeled baseline climate change scenario, when compared to the modeled baseline scenario.

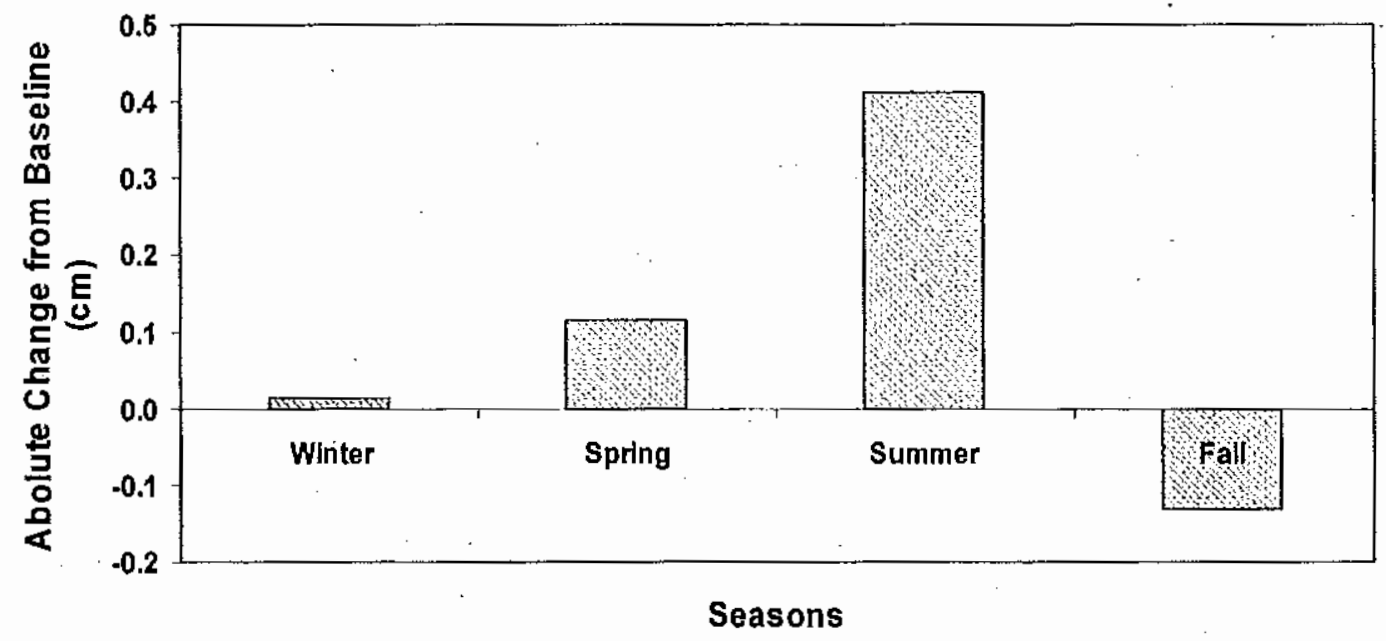

Figure 19: Modeled absolute change from the baseline scenario in mean seasonal ET from the baseline climate change scenario. 


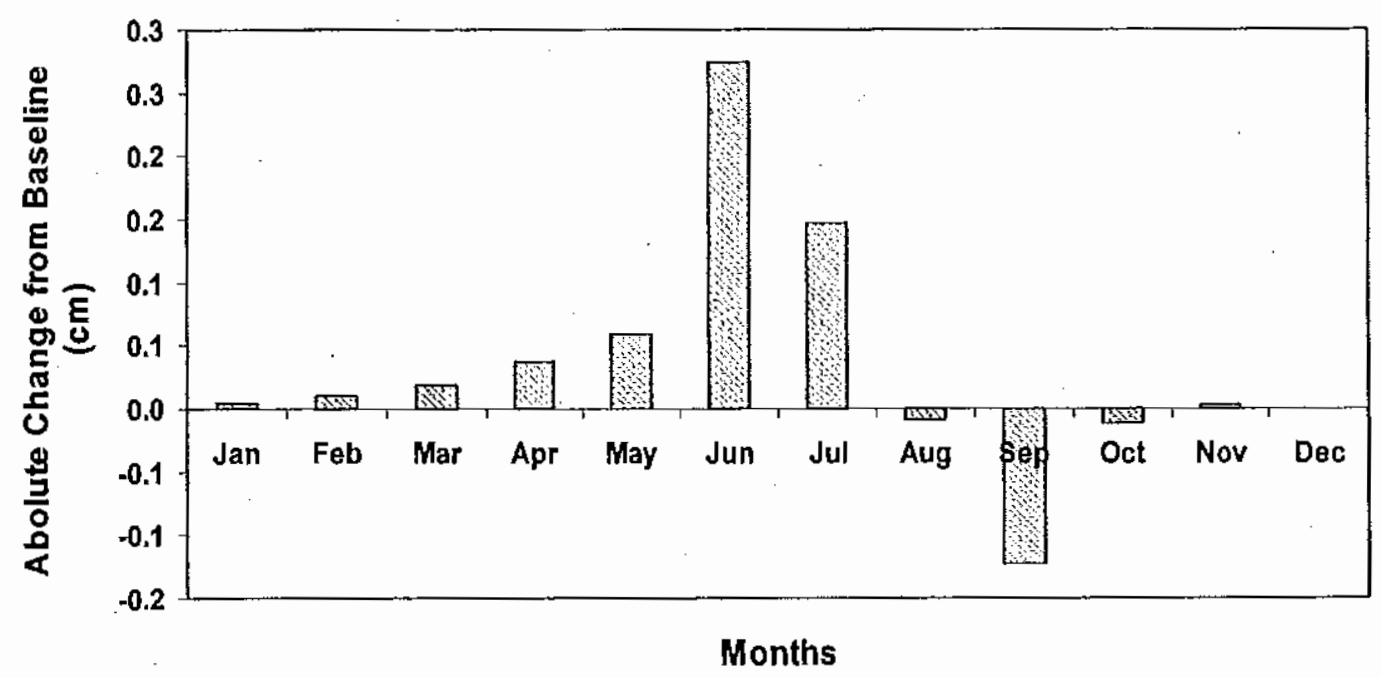

Figure 20: Modeled absolute change from the baseline scenario in mean monthly ET for the baseline climate change scenario.

Table 16: Modeled mean annual runoff depths produced by the baseline scenario and the baseline climate change scenario.

\begin{tabular}{|l|c|c|}
\hline Scenario & Runoff $(\mathrm{cm})$ & \% Change From Baseline \\
\hline Baseline & 57.282 & \\
Baseline + CC & 58.801 & 2.65 \\
\hline
\end{tabular}

Table 17: Modeled mean annual ET volumes produced by the baseline scenario and the baseline climate change scenario.

\begin{tabular}{|l|c|c|}
\hline Scenario & ET (cm) & \% Change From Baseline \\
\hline Baseline & 37.465 & \\
Baseline + CC & 37.876 & 1.097 \\
\hline
\end{tabular}




\subsubsection{Runoff Response to Land Cover and Climate Change}

Seasonal (Table 18) and monthly (Table 19) results from each of the three combined land and climate scenario models show that, when compared to the baseline, the Sprawl scenario generates the largest absolute runoff change of the three scenarios during the winter season $(+1.36 \mathrm{~cm})$. The Planned scenario generates the largest absolute runoff change during the fall season $(+1.83 \mathrm{~cm})$.

Table 18: Modeled total and percent changes in mean seasonal runoff volumes $(\mathrm{cm})$ in the RCB for the baseline climate change scenario and each of the PNWERC land change scenarios for 2040 with climate change, when compared to the baseline scenario.

\begin{tabular}{|l|c|c|c|c|c|}
\hline \multicolumn{2}{|c|}{} & \multicolumn{4}{|c|}{ Land Cover Scenarios with Climate Change } \\
\hline Month & Baseline (cm) & Baseline & Compact & Sprawl & Planned \\
\hline Winter & 27.338 & $0.709(2.6)$ & $1.330(4.9)$ & $1.356(5.0)$ & $1.292(4.7)$ \\
\hline Spring & 18.254 & $0.640(3.5)$ & $-0.014(-0.1)$ & $0.036(0.2)$ & $-0.029(-0.2)$ \\
\hline Summer & 5.615 & $-0.092(-1.6)$ & $-0.091(-1.6)$ & $-0.075(-1.3)$ & $-0.089(-1.68)$ \\
\hline Fall & 6.075 & $0.262(4.3)$ & $1.823(30.0)$ & $1.807(29.8)$ & $1.826(30.1)$ \\
\hline
\end{tabular}




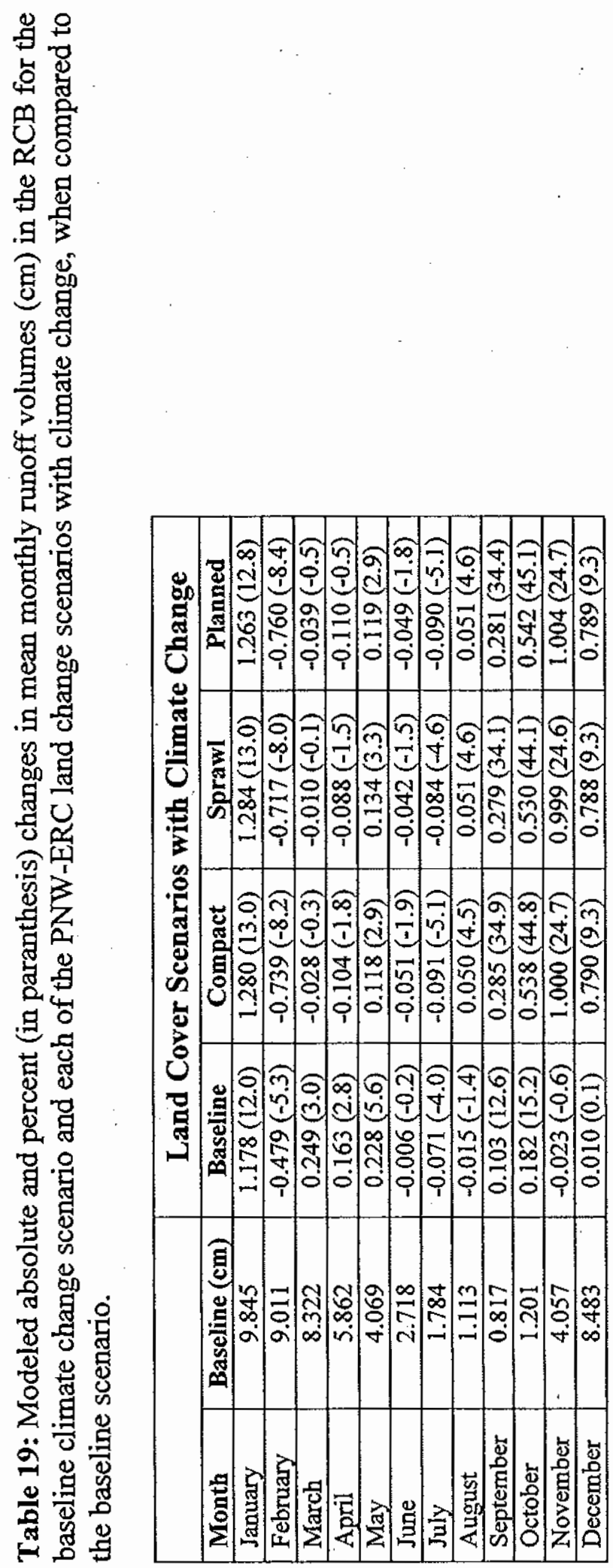


ET results show that for all the land cover scenarios, the largest change in ET will occur from a reduction during the summer months, but particularly during the months of July, August, and September (see Figure 20). This is in contrast to the baseline climate change scenario, which experiences an increase in ET during the summer (see Figure 21).

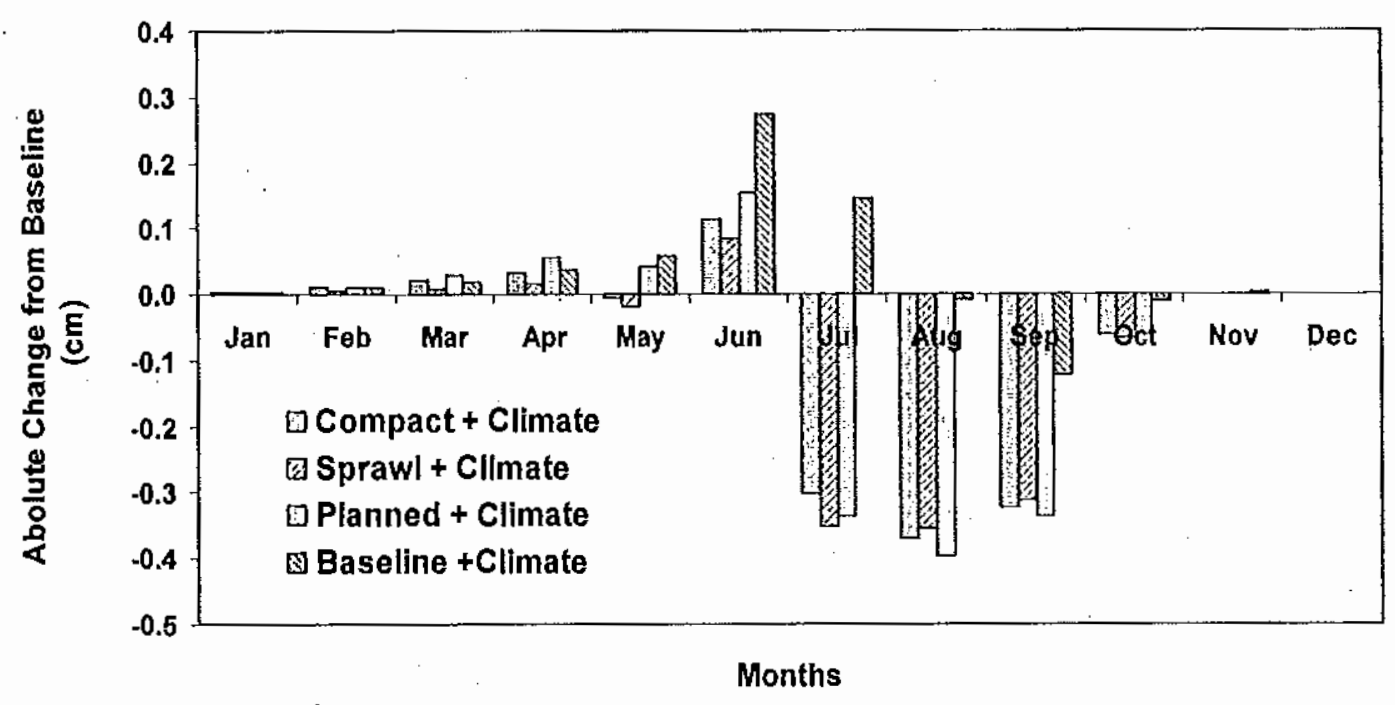

Figure 21: Modeled absolute change in monthly ET volume fiom the baseline scenario for the baseline climate change scenario and the three PNW-ERC land cover scenarios with climate change. 


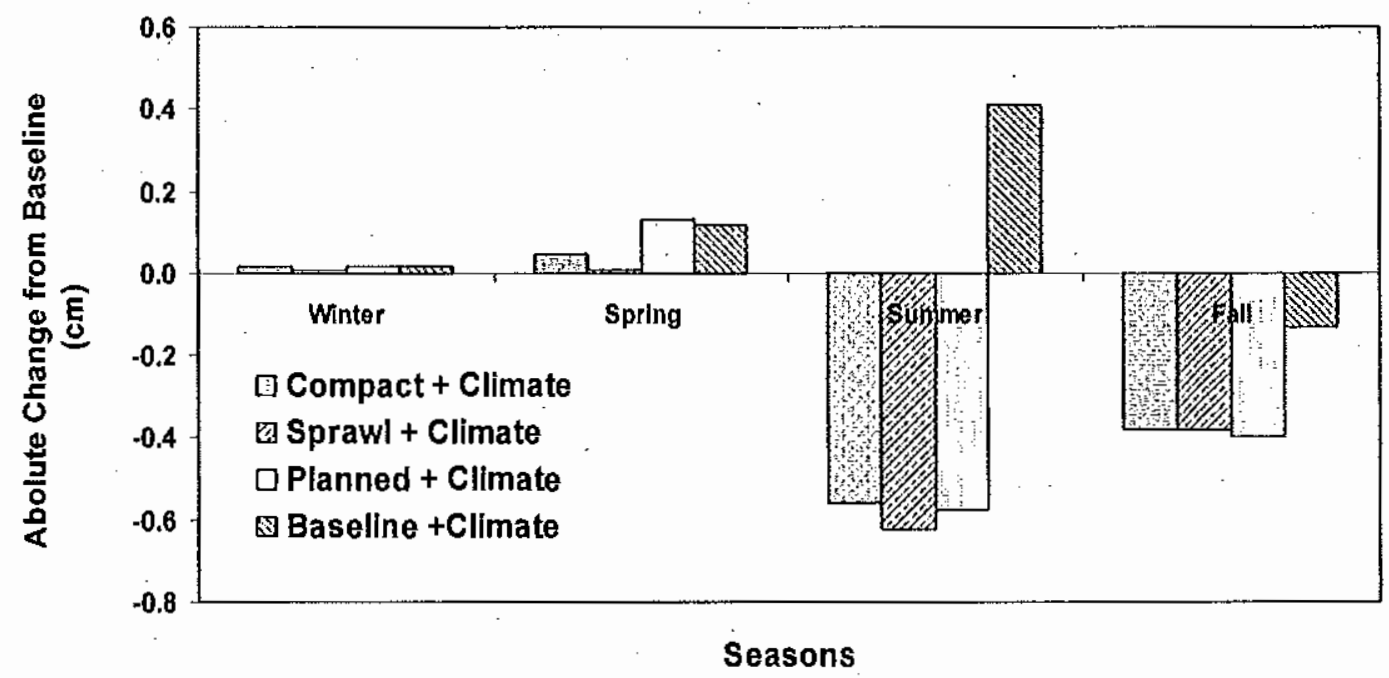

Figure 22: Modeled absolute change in seasonal ET volume from the baseline scenario for the baseline climate change scenario and the three PNW-ERC land cover scenarios with climate change.

Although the absolute change in runoff depth is slight in spring and summer for each of the scenarios, the Sprawl scenario shows the only positive result of the three (Figure 22). Each of the land cover scenario models generates the largest increase in runoff depths during the fall season, similar to their model results without climate change. The combined land cover and climate change model results each exhibit a considerable increase in mean annual runoff depths from both baseline scenarios (Table 20). Out of the three scenarios, the sprawl scenario displays the largest mean annual depth, with a total of $60.41 \mathrm{~cm}$, a 5.5 percent change from the baseline estimates. 


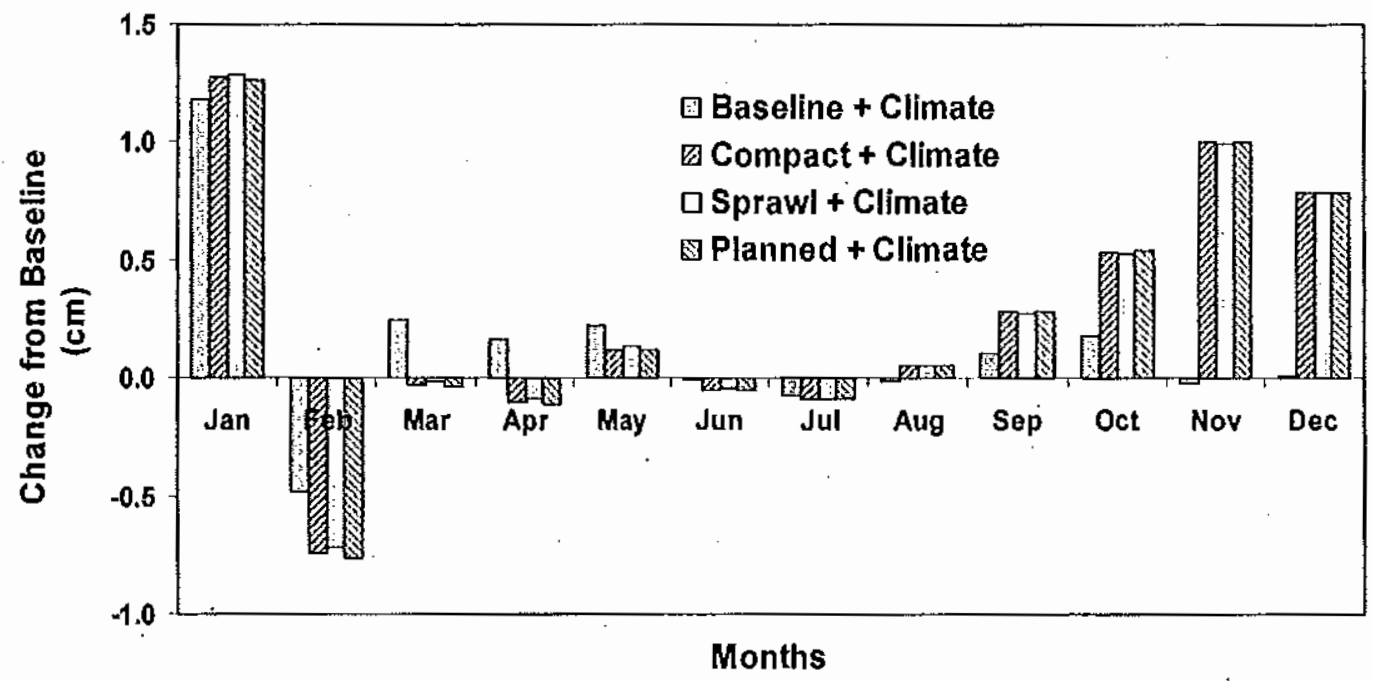

Figure 23: Modeled absolute changes in mean monthly runoff volume $(\mathrm{cm})$ for the RCB for the baseline climate change scenario and each of the PNWERC land change scenarios with climate change, when compared to the baseline scenario with climate change.

Table 20: Modeled mean total annual runoff volumes produced by the baseline and each of the PNW-ERC land change scenarios for 2040 with climate change.

\begin{tabular}{|l|c|c|}
\hline Scenario & Runoff $(\mathrm{cm})$ & \% Change From Baseline \\
\hline Baseline (2001) & 57.282 & \\
Compact + CC & 60.331 & 5.32 \\
Sprawl + CC & 60.407 & 5.45 \\
Planned + CC & 60.282 & 5.24 \\
\hline
\end{tabular}

When compared to the majority of monthly runoff depth results from the baseline climate change scenario, the PNW-ERC land cover/climate change scenarios each produce an amplified amount of runoff (Figure 23). The exception to this trend occurs in month of March, April, August, and November, where the 
direction in runoff increases or decreases opposed each other. The largest dissimilarity occurs in November, where the PNW-ERC scenarios exhibited the highest increase in absolute volume from the baseline scenarios, while the baseline climate scenario produced a slight decrease. At the seasonal scale, runoff depths for the fall and winter were again amplified when compared to the baseline with climate change; however, the summer results are generally the same, while spring volumes seem to be underestimated. The largest absolute annual change in runoff depth from the baseline climate change scenario occurs from the sprawl scenario, which exhibits a $1.61 \mathrm{~cm} /$ year, or 2.73 percent, increase.

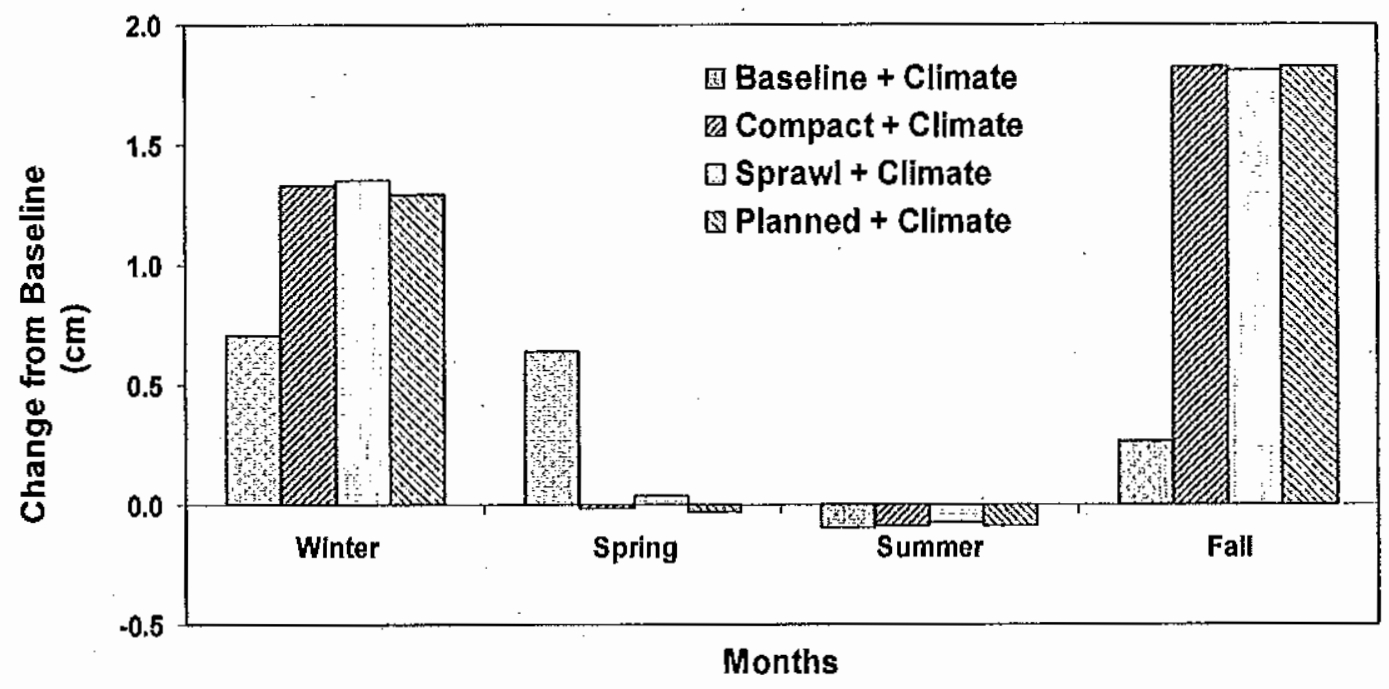

Figure 24: Modeled absolute changes in mean seasonal runoff volume $(\mathrm{cm})$ for the RCB for the baseline climate change scenario and each of the PNW-ERC land change scenarios with climate change, when compared to the baseline scenario with climate change. 


\section{DISCUSSION}

\subsection{Influences of Climate Change in the RCB}

The temperature and precipitation modifications derived from the ECHAM5 climate model signify a moderate change in the overall climate centered on the RCB. The inclusion of the results from several other climate models would provide a range of possible future paths for this time period and region, but was beyond the scope of this study. Therefore, the extremes of climate projections are not represented, but instead a reasonable estimation of how the climate in the RCB of Pacific Northwest will be characterized between 2030 and 2059

When evaluating the influence of climate change on river runoff amounts between the Rock Creek study and other previous studies, comparisons are influenced by the types of hydrological models used and study area characteristics. In other basins throughout the western United States, climate change has had various affects on runoff. Many of the watersheds studied in this region are transitional, meaning that their runoff characteristics are influenced by both winter precipitation and spring snowmelt. VanRheenen et al. (2004) used the statistically downscaled results from the DOE/NCAR Parallel Climate Model (PCM) (1/8degree resolution) with a 'business-as-usual' emissions scenario to assess runoff affects in the Sacramento - San Joaquin River basins. They calculated a $1.2^{\circ} \mathrm{C}$ increase in mean annual temperature throughout the mid-century and a 10 to $25 \%$ decrease in precipitation. Reduced precipitation would occur primarily in winter 
and spring, beginning in 2020 , becoming similar to the baseline $(1950-1999)$ by mid-century, and then decline again by 2080 . Climate change results input into the distributed Variable Infiltration Capacity (VIC) hydrology model determined that the Sacramento - San Joaquin River would experience winter, spring, and summer reductions in runoff volumes (actual numbers not available). In an analysis of the semi-arid Colorado River basin using the same climate and hydrology model as VanRheenen et al. (2004), Christensen et al. (2004) calculated a range of 1.0 to $1.7^{\circ} \mathrm{C}$ increase in temperature and a 3 to 6 percent reduction in mean annual precipitation for the $2010-2067$ time periods. As a result, the Colorado River would experience a $14-18 \%$ reduction in annual runoff between 2010 and 2069 . Runoff results from both studies are in part the result of less snowfall and earlier snowmelt in the spring. Because the RCB is rain-fed, its runoff response will not be influenced by changes in snowmelt conditions, which accounts for some of the differences in results among these studies.

When compared to previous climate impact studies within the Pacific Northwest, temperature and precipitation changes from the ECHAM5 results are mixed. The research projects warming trends throughout the entire Pacific Northwest region, but tends to show a slightly higher increase, on average, than this study. This is most likely the result of the smaller scale of this research compared to the larger scale PNW studies. Rock Creek is located at a low elevation and is a rain-fed basin, and shows less sensitivity to projected changes in temperature, 
which affects snowmelt and subsequently runoff. There is also a trend of more warming in higher elevations than lower elevations due to the albedo effect. As the snow line retreats, new vegetated surface emerges. Dark surface is likely to decrease albedo, which in turn leads to surface warming (Foley et al. 2005):

Results from regional studies are useful for comparison because of the assumption that their projected changes in climate will be somewhat similar. The Climate Impacts Group (CIG) used an ensemble of twenty climate scenarios to project an average annual temperature increase of $1.6^{\circ} \mathrm{C}\left(2.9^{\circ} \mathrm{F}\right)$ throughout the Pacific Northwest between 2030 and 2060 , with a range of $0.8^{\circ} \mathrm{C}\left(1.4^{\circ} \mathrm{F}\right)$ to $2.6^{\circ} \mathrm{C}$ $\left(4.6^{\circ} \mathrm{F}\right)$. Annual precipitation between the same time periods was projected to change an average of $+6 \%$, with a range of $-2 \%$ to $+18 \%$, although most changes will generally mimic natural variability until the late $21^{\text {st }}$ Century. Overall climate patterns revealed warmer, wetter winters with warmer, drier summers (Mote et al. 2005, IPCC 2007). Using eight regional GCMs, Mote et al. (2003) estimated the average regional warming at $2.3^{\circ} \mathrm{C}$ by the 2040 s for the entire PNW. They found that a slight decrease in summer rainfall combined with wetter winters would create only a modest increase in annual precipitation.

Studies that focused on basins of much closer proximity to the RCB found somewhat similar climate change results, although runoff patterns were varied because of the differing sizes and characteristics of each watershed. Climate change projections for Rock Creek were much closer to those found throughout the 
Columbia River basin by Payne et al. (2004). By using both the statistically downscaled results from the PCM climate model and results from a Regional Climate Model (RCM) at 1/2-degree resolution, they predicted mean annual temperatures increases of $0.5^{\circ} \mathrm{C}$ between 2010 and 2039 and $1.3^{\circ} \mathrm{C}$ between 2040 and 2069, whereas winter precipitation would change by -3 and +5 percent, respectively. When these climate inputs were applied to the VIC hydrology model, it was determined that the Columbia River would experience a -5 to $0 \%$ change in annual average runoff volume, with higher flows during the winter and spring and lower flows in the summer.

Warming by 2040 in the RCB tended to be slightly less than found in the Bull Run watershed $\left(2.0^{\circ} \mathrm{C}\right)$ by VanRheenen et al. (2003), which used statistically downscaled outputs from four GCMs, including ECHAM4. Mean annual precipitation would also increase slightly. Climate changes input into the Distributed Hydrology, Soil-Vegetation Model (DHSVM) determined that stream flows during the winter would increase as spring-time runoff decreases. Warming within the RCB fell just below the 1.3 to $3.5^{\circ} \mathrm{C}$ increase in the Clackamas River basin between 2020 and 2080 found by Graves and Chang (2007). The results of two GCMs (HadCM2 and CCC) input into a GIS-based distributed hydrology model projected a $13.7-46.4 \%$ increase in winter runoff, depending on the GCM used. Climate results for Bull Run basin, the Clackamas River basin, and the Rock Creek basin all found a slight increase in mean annual precipitation amounts. At the 
seasonal scale, the reduction in summer rainfall and increase in winter rainfall for Rock Creek mirrors these studies results; however, VanRheenen et al. (2003) showed a reduction in spring precipitation for the Bull Run basin. According to this study, Rock Creek will experience a seasonal shift in precipitation, whereby the major increase will be occurring in the spring with a moderate increase in the fall and winter. Monthly precipitation projections for Rock Creek generally follow. previous results for the region, although the February reduction was not recorded by any other studies.

A report by Palmer et al. (2004) for the Hagg Lake region of the Tualatin River basin offers an interesting comparison to the results of this study because of Hagg Lake's close proximity to Rock Creek (the same basin) and the report's use of the BASINS hydrology model, a model related to AVSWAT-X and similarly developed by the USDA. Using statistically downscaled outputs from six GCMs, warming within the Tualatin River basin for 2040 was virtually identical to the findings of this study. However, unlike this study, they found that, with the exception of increased drying in August, trends in monthly precipitation for 2040 were similar to the 2000 climate and did not start to dramatically change until 2050. The discrepancy between monthly precipitation patterns in the Tualatin basin and Rock Creek sub-basin could be the result of their averaging of the multiple climate scenarios, while this study used only one scenario.

The Hagg Lake region, situated in a more rural section of the Tualatin basin 
than Rock Creek, is projected to experience reduced annual stream flow by 2040 , when compared to the historic patterns. This will be driven by a $10-20 \%$ decrease in summer stream flow. Although mean annual and winter precipitation is expected to increase, rising temperatures and increases in ET will impact runoff during the late-spring and summer. By contrast, the mean summer runoff in the RCB will only fall approximately $2 \%$ by 2040 , with minimal increases in ET. This difference in runoff patterns from the two studies is most likely the result of a smaller amount of ET occurring in the RCB because of comparatively less plant cover and more impervious surfaces increasing the flashiness of runoff.

There were noticeable differences in seasonal and monthly responses between the two studies. In Rock Creek, the seasonal runoff response followed changes in precipitation due to climate change in the summer and fall; however, the increase in runoff compared to precipitation was higher during the winter than the spring. The spring showed the largest relative change in seasonal precipitation, yet failed to illicit a similar response to spring runoff. At Hagg Lake, winter and spring inflows are expected to decline by 2040, but increase between February and April by 2060 . Both studies show decreases in summer flow. Monthly results from the impact of climate change on baseline runoff in the RCB suggest that the overall runoff response generally followed the precipitation adjustments. At the seasonal scale, changes in winter runoff exceeded those of spring runoff, even though the spring season experienced a much greater increase in precipitation. One possible 
explanation is that the high increase in January runoff was able to dampen the runoff response to reduced February precipitation, possibly from increased soil saturation or groundwater lag. This may have allowed the change in winter season runoff to surpass that of the spring. Modifications in monthly and seasonal ET at Hagg Lake and Rock Creek generally followed the expected patterns, exhibiting the highest increases during the summer months.

\subsection{Influences of Land Cover Change in the RCB}

The changes in mean annual runoff volume created by each of the PNWERC land cover scenarios were similar to several other previous urban growth impact studies in direction, but not necessarily in magnitude. Through the use of the lumped physical model, L-THIA, Grove et al. (2001) found that as urban growth developed between 1973 and 1991, annual runoff depths in the Little Eagle Creek watershed, Indiana $\left(70.5 \mathrm{~km}^{2}\right)$ increased by $6.8 \mathrm{~cm}$, with a range of 0.8 to $10.2 \mathrm{~cm}$ in its five sub-basins. Although no estimate of the amount of urbanization was given, the changes generally depended on the amount of cultivated land replaced by urban cover. Although the Rock Creek results $(+2.5 \%$ in annual runoff depth) fall within the range of change found by Grove et al. (2001), their results exhibit a much higher average increase over a smaller watershed size. One possible reason for the discrepancy is that the Grove et al. (2001) analysis was conducted during the watershed's initial period of rapid urban growth, when it was transformed from primarily grass and forest to mainly urban land cover. This 
contrasts with the Rock Creek baseline scenario where over $50 \%$ of the watershed was already urbanized with the baseline scenario. This could account for the large difference in volume results between the two studies.

Similarly, using sprawl and non-sprawl urban growth scenarios to study urbanization in Muskegon River watershed, near Lake Michigan $\left(7,032 \mathrm{~km}^{2}\right)$, Tang et al. (2005) found that between 1978 and 2040, runoff depths would increase 5\% and $12 \%$ for sprawl and non-sprawl scenarios, respectively. Differences in runoff results between each of the PNW-ERC scenarios were also supported by Grove et al. (2001) and Tang et al. (2005), which also determined that unchecked urban growth produced the highest increases in annual runoff. This followed the findings of the Rock Creek study: that the sprawl scenario (low-density, unchecked urban growth) would produce the highest increase in annual runoff depth, while the planned and compact scenarios (higher-density urbanization) showed smaller increases in annual runoff depth, comparatively. According to Scheuler (1994), lower runoff volumes resulting from greater density urbanization is likely the result of the creation of 'urban center's' that limit the amount of impervious surfaces and exhibit less channel connectivity for storm drainage throughout the basin.

Each of the PNW-ERC scenarios exhibited slightly different ET results. A wider distribution of urban land cover throughout the RCB (sprawl scenario) also produced the largest decreases in summer ET. Although the cause of these phenomena was not extensively researched in this study, there are several possible 
explanations. These reductions in ET may have been caused by the increased flashiness and channelization of runoff due to increased impervious surfaces, thus providing less water available for ET (Dunne and Leopold 1994, Taha 1997, Dingman 2002). Another contributing factor could be the replacement of the existing plant canopy with impervious surfaces, thus reducing the amount of transpiration taking place (Coutts et al. 2007). The mean annual reduction in ET likely influenced the resulting increase in fall runoff for all land cover scenarios, as less summer ET would result in higher soil water saturation and eventually contribute to a higher runoff response later in the year.

\subsection{Effects of Climate Change and Urbanization}

In this study, the Rock Creek models that accounted for both climate and urban land cover change produced amplification in the magnitude of mean annual runoff volumes and ET, when compared to runoff results from the baseline and either the climate scenario or the land cover scenarios. Recent studies in other environments show similar effects from modeling the combined change on urban land cover and climate. In a study comparing the impact of climate change between 39 urban and 21 rural watersheds throughout the United States, DeWalle et al. (2000) used a regression model combining changes in mean annual temperature and precipitation due to climate change with population density as a proxy for measuring urbanization to estimate mean annual stream flow. Climate change data were created using 10 different synthetic climate change scenarios, modifying 
temperature from $0^{\circ} \mathrm{C}$ to $+4^{\circ} \mathrm{C}$ and precipitation from $-20 \%$ to $+20 \%$. Their research found that with a $10 \%$ increase in mean annual precipitation coupled with a $2 \%$ rise in mean annual temperature, urban watersheds exhibited a $15 \%$ increase in mean annual stream flow. The same climate change scenario only produced an $8 \%$ change in mean annual streamflow in rural basins. Barlage et al. (2002) studied the potential change in runoff between 2090 and 2099 from the Huron River watershed $\left(2,230 \mathrm{~km}^{2}\right)$ in Southeastern Michigan, using climate outputs from the Hadley Coupled Climate Model (HadCM2) to drive the distributed Biosphere-Atmosphere Transfer Scheme (BATS/HYDRO) hydrology model. The land cover scenario used was constructed from the local government's growth projections for 2020. They found that changing both climate and urban land use resulted in a $4.3 \%$ increase in the percentage of precipitation to surface runoff from the baseline $(1994-2003)$, compared to $2.5 \%$ with only climate change modeled with baseline land cover and $1.6 \%$ with only the land cover change scenario. The largest decrease in precipitation to surface evaporation was also produced from the combined climate and land change scenario, which undoubtedly contributed to the increased runoff. This exhibits a greatly amplified increase in runoff results when both factors are combined in the modeling process.

As previous climate and land cover change studies only address runoff or stream flow changes at the mean annual scale, this study provides an opportunity for the analysis of inter-annual variability brought on by both factors. The 
combined climate and land cover scenarios produced the largest increases in runoff depth in the fall and winter compared to the baseline, indicating that the timing of seasonal runoff will start earlier in the water year and end earlier as well. This was evident in the large increase in November runoff and decrease in February. Although this pattern matched the land cover scenario results, runoff depths were considerably higher for the combination scenarios $(+5.1 \%$ in winter and $+23.5 \%$ in fall for the sprawl scenario) compared to the land cover scenarios only $(+1.9 \%$ in winter and $+18.4 \%$ in fall for the sprawl scenario). However, the reduction in spring runoff exhibited by the land cover scenarios was not seen in the combination scenarios. This could be the result of a runoff lag from higher winter precipitation produced by climate change. Monthly and seasonal differences were also found between the combination scenarios and the climate change baseline. The greatest differences were the result of large increases in November and December from the combination scenarios, greatly amplifying the fall and winter response, while almost no change occurred with the climate change baseline. Spring showed very little change in runoff compared to the climate change scenario, indicating a possible dampening effect caused by urbanization for this part of the year. Although climate change projected an increase in rainfall during the spring, it is possible the reduction in runoff during late winter allowed for the absorption of precipitation into the soils once the rainfall increased again in March, thus carrying over the reduction of runoff to the subsequent spring months. Overall, these 
findings further support the amplification of runoff that has been found in previous climate and land cover change studies.

\subsection{Caveats}

As previously noted, there is a certain measure of uncertainty inherent in attempting to model the natural world. Therefore, it is important to emphasize certain assumptions and caveats that were made in the development of this study. First, five years of Rock Creek runoff data available for the calibration and validation of the AVSWAT-X hydrology model may have affected the model's accuracy in estimating runoff for longer time periods. While five years of data provides a 'snapshot' of river characteristics, it would not necessarily be able to fully capture the runoff variations that would occur over 30 years or more.

Second, it is possible that the differences in the categorization of land types between the baseline and the PNW-ERC scenarios within the AVSWAT-X model introduced a measure of uncertainty in modeling runoff. Because the PNW-ERC datasets contained a much greater number of land cover category types than those of the NRCS2001 dataset, introducing an amount of subjectivity into the modeling method was inevitable.

Third, the climate change scenario used in this study is considered to be a moderate projection of future climate of the RCB. The addition of the projections from several other climate models would offer a wider range of possible outcomes 
for the 2040 time period. It might also better illustrate the non-linear response of runoff depths to greater changes in precipitation and temperature.

Finally; analysis at the daily time scale might provide a more revealing method for assessing changes in runoff caused by the impacts of urban growth. Urbanization tends to cause increased flashiness of runoff in response to storm events, which would be better captured at the daily scale (Chang 2007). Monthly and seasonal scales may be too coarse to pick up the most telling signals of change. 


\section{CONCLUSIONS}

The Rock Creek basin is projected to experience modifications in the timing and volume of runoff during the mid $21^{\text {st }}$ Century caused by continued urban growth and climate changes. An assessment of the RCB using regionally specific downscaled climate and land cover scenarios and a GIS-based semi-distributed hydrologic model was effective in quantifying these impacts. The hydrologic model AVSWAT-X was successfully calibrated for the 2001-2003 period $\left(\mathrm{R}^{2}=0.90\right)$ and validated for the $2004-2005$ period $\left(R^{2}=0.66\right)$ using contemporary climate and runoff data, as well as available GIS data of the physical characteristics of the study area. Monthly, seasonal, and annual runoff depth and ET were calculated for the entire basin for the contemporary period, $1973-2002$, and the future time period, $2030-2059$.

The results of this study support the hypothesis that the combination of both climate change and urbanization would amplify the runoff from the RCB during the $21^{\text {st }}$ Century. Statistically downscaled climate change results from the ECHAM5 GCM found that the region would experience an increase of $1.2^{\circ} \mathrm{C}$ in the average annual temperature and a $6 \%$ increase in average annual precipitation between 2030 and 2059. These climate changes are within the range projected by the majority of other regional studies for this time period. This study projects an $8 \%$ to $15 \%$ expansion of urban land use throughout the RCB will result in a $2.3 \%$ to. $2.5 \%$ increase in annual runoff depths, respectively. Distribution of urban land use 
throughout the $\mathrm{RCB}$ also impacted runoff characteristics, with compact urban growth producing the smallest increase in runoff depth. Projected climate changes for the basin using land cover for 2001 resulted in a $2.7 \%$ increase in mean annual runoff depth. These changes would primarily occur during the spring $(+3.5 \%)$ and winter $(+2.6 \%)$, with reductions during the summer season $(-1.7 \%)$. However, when changes in both climate and urban land cover are considered, results reveal amplification in runoff depth for the basin. The urban sprawl scenario produced the highest increase in runoff depth $(+5.5 \%)$ under the climate scenario, while urbanization reflecting current regional growth plans produced the lowest increase (+5.2). An amplification of runoff resulting from the combination of urbanization and climate changes, when compared to only climate or urban land changes, was one of the significant findings of this study.

One of the primary strengths of this research is its inclusion of climate and land cover scenarios designed specifically for the $\mathrm{RCB}$ and surrounding area. The three land cover scenarios provided by the PNW-ERC were created specifically for determining the affect of land use planning on the environment, as well as assisting in alternative futures analysis. Because these datasets were designed with the help of regional stakeholders, scientists, and policy makers, they are able to present more realistic projections of potential growth in the basin. Similarly, the highresolution climate scenario made available by the $\mathrm{CIG}$ is able to provide a more robust projection of how climate may change in the future within the RCB. The 
ECHAM5 GCM accurately reproduces the $20^{\text {th }}$ century climate and is also considered able to well-represent possible future regional climate change. The temperature and precipitation data from the ECHAM5 GCM is the most current assessment for the basin, using the most up-to-date climate model and downscaling techniques available. Finally, this study also investigates the influence that differing urban densities within a watershed can have on runoff. When coupled with climate change effects, this study is able to make a contribution to the small, but growing, amount of research on this subject.

Several assessments have determined that the combined affect of climate and urban land cover changes during the $21^{\text {st }}$ Century would produce amplified runoff results, when compared to research only considering one of these variables. Results from this study agree with previous research and suggest that the direction of these impacts would be similar in urbanizing watersheds of comparable size. The robustness of this study, however, is limited by its use of only one climate scenario in the analysis and the availability of a short time period of runoff data from which to calibrate and validate the hydrologic model. This illustrates the complexity of modeling natural systems and emphasizes the necessity for considering both climate and land cover changes at different scales in future runoff impact assessinents.

Future opportunities for related research include the use of downscaled climate data from different GCMs and introducing updated urbanization scenarios, 
as they are available. Expanding the different sources of data and models would help increase the confidence water resource managers may have in assessment results and provide a measure of uncertainty to better help them evaluate possible risk. Water resource managers would also benefit from research evaluating how changes in the timing and volume of runoff from urban watersheds would affect water quality. As the population of the RCB increases, the natural stream system will become more stressed, making it increasingly difficult to maintain acceptable water quality. The methodology used in this study would be a positive step toward creating more realistic runoff assessments that would assist water resource managers in developing more resilient water resource policies for the future. 


\section{REFERENCES}

Alig, R.J., J.D. Kline, and M. Lichtenstein. 2004. Urbanization on the U.S. landscape: Looking ahead in the 21st Century. Landscape and Urban Planning 69(13): 219-234.

Arnell, N. 2000. Thresholds and response to climate change forcing: The water sector. Climalic Change 46(3): 305-316.

Arnell, N. 2004. Climate change and global water resources: SRES emissions and socioeconomic scenarios. Global Environmental Change 14(1): 3-20.

Arnold, J.G., P.M. Allen, R. Muttiah and G. Bernhardt. 1995. Automated base flow separation and recession analysis techniques. Ground Water 33(6): 1010-1017.

Arnold, J.G., and P.M. Allen. 1999. Automated methods for estimating baseflow and ground water recharge from streamflow records. Journal of the American Water Resources Associalion 35(2): 411- 424.

Arnold, J.G., and N. Fohrer. 2005. SWAT2000: Current capabilities and research opportunities in applied watershed modeling. Hydrological Processes 19(3): 563-572.

AVSWAT-X. 2006. ArcView SWAT, version 2005. From Soil and Water Assessment Tool (SWAT), SWAT2005 Interfaces website. URL: http://www.brc.tamus.edu/swat/avswat.html. Downloaded: 03/01/2007.

Baker, J.P., D.W. Hulse, S.V. Gregory, D. White, J. Van Șickle, P.A. Berger, D. Dole, and N.H. Schumaker. 2004. Alternative futures for the Willamette River Basin. Ecological Applications 14(2): 313-324.

Barlage, M.J., P.L. Richards, P.J. Sousounis, and A.J. Brenner. 2002. Impacts of climate change and land use change on runoff from a Great Lakes watershed. Journal of Great Lakes Research 28(4): 568-582.

Barnett D.N., S.J. Brown, J.M. Murphy, D.M. Sexton, and M.J. Webb. 2006. Quantifying uncertainty in changes in extreme event frequency in response to doubled $\mathrm{CO} 2$ using a large ensemble of GCM simulations. Climate Dynamics 26(5): 489-511. 
Beighley, R.E. and G.E. Moglen. 2002. Trend assessment in rainfall-runoff behavior in urbanizing watersheds. Journal of Hydrologic Engineering 7(1): 27-33.

Benaman, J., C.A. Shoemaker and D.A. Haith. 2005. Calibration and validation of Soil and Water Assessment Tool on an agricultural watershed in Upstate New York. Journal of Hydrologic Engineering 10(5): 363-374.

Bergstrom, S., B. Carlsson, M. Gardelin, G. Lindstrom, A. Pettersson, and M: Rummukainen. 2001. Climate change impacts on runoff in Sweden Assessments by global climate models, dynamical downscaling and hydrological modeling. Climate Research 16(2): 101-112.

Booth, D.B., D. Hartley, and R. Jackson. 2002. Forest cover, impervious-surface area, and the mitigation of storm water impacts. Journal of the American Water Resources Association 38(3): 835-845.

Bos, R., C. Caudill, J. Chilton, E.M. Douglas, M. Meybeck, D. Prager. 2005. Fresh Water. In Ecosystems and Human Well-being: Current State and Trends. Millennium Ecosystem Assessment, Island Press, USA.

Bosch, D.J., V.K. Lohani, A.M. Asce, R.L. Dymond, M. Asce, D.F. Kibler, M. Asce, and K. Stephenson. 2003. Hydrological and fiscal impacts of residential development: Virginia case study. Journal of Water Resources Planning and Management 129(2): 107-114.

Bouraoui, F., B. Grizzetti, K. Granlund, S. Rekolainen and G. Bidoglio. 2004. Impact of climate change on the water cycle and nutrient losses in a Finnish catchment. Climatic Change 66(1-2): 109-126.

Chang, H. 2003. Basin hydrologic response to changes in climate and land use: The Conestoga River basin, Pennsylvania. Physical Geography 24(3): 222-247.

Chang, H. 2007. Comparative stream flow characteristics in urbanizing basins in the Portland Metropolitan Area, Oregon, USA. Hydrological Processes 21(2): 211-222.

Chen, J.F., Li, X., and Zhang, M. 2005. Simulating the impacts of climate variation and land-cover changes onbasin hydrology: A case study of the Suomo basin. Science in China Series D Earth Sciences 48(9): 1501-1509.

Chin, A. 2006. Urban transformation of river landscapes in a global context. Geomorphology 79(3-4): 460-487. 
Choi, W. 2004. Climate change, urbanization and hydrological impacts.

International Journal of Global Environmental Issues 4(4): 267-285.

Christensen, N.S., A.W. Wood, N. Voisin, D.P. Lettenmaier, and R.N. Palmer. 2004. The effects of climate change on the hydrology and water resources of the Colorado River basin. Climatic Change 62(1-3): 337-363.

Claessens, L., C. Hopkinson, E. Rastetter, and J. Vallino. 2006. Effect of historical changes in land use and climate on the water budget of an urbanizing watershed. Water Resources Research 42(3): 1-13.

Coutts, A.M., J. Beringer, and N.J. Tapper. 2007. Impact of increasing urban density on local climate: Spatial and temporal variations in the surface energy balance in Melbourne, Australia. Journal of Applied Meteorology and Climatology 46(4): 477-493.

DeFries, R. and K.N. Eshleman. 2004. Land-use change and hydrologic processes: A major focus for the future. Hydrological Processes 18(11): 2183-2186.

DiLuzio, M., R. Srinivasan, J.G. Arnold, and S.L. Neitsch. 2002. ArcView Interface for SWAT2000: Users Manual. Grassland and Water Research Laboratory \& Blackland Research Center, Temple, Texas, USA.

DiLuzio, M., J.G. Arnold, and R. Srinivasan. 2005. Effect of GIS data quality on small watershed stream flow and sediment simulations. Hydrological Processes 19(3): 629-650.

DeWalle, D.R., B.R. Swistock, T.E. Johnson, and K.J. McGuire. 2000. Potential effects of climate change and urbanization on mean annual stream flow in the United States. Water Resources Research 36(9): 2655-2664.

Dingman, S.L. 2002. Physical Hydrology, $2^{\text {nd }}$ Edition. Prentice-Hall, Inc., Upper Saddle River, New Jersey.

Duan, Q., S. Sorooshian, and V.K. Gupta. 1992. Effective and efficient global optimization for conceptual rainfall-runoff models. Water Resources Research 28(4): 1015-1031.

Dunne, T., and L.B. Leopold. 1978. Water in Environmental Planning. W.H. Freeman and Company, New York.

Eckhardt, K. and J.G. Arnold. 2001. Automatic calibration of a distributed catchment model. Journal of Hydrology 251(1-2): 103-109. 
Eckhardt, K., S. Haverkamp, N. Fohrer and H.G. Frede. 2002. SWAT-G, a version of SWAT99.2 modified for application to low mountain range catchments. Physics and Chemistry of the Earth 27(9-10): 641-644.

Eckhardt, K. and U. Ulbrich. 2003. Potential impacts of climate change on groundwater recharge and stream flow in a central European low mountain range. Journal of Hydrology 284(1-4): 244-252.

Eckhardt, K., N. Fohrer and H.G. Frede. 2005. Automatic model calibration. Hydrological Processes 19(3): 651-658.

Edmonston, B., E.D. Pepos, and S. Stewart. 2003. Metropolitan Portland Vancouver Major Population Trends. Population Research Center, Portland State University website. URL: http://www.upa.pdx.edu/CPRC/publications/oregonoutlook.html: Downloaded: 08/21/2007.

El-Nasr, A.A., F.G. Arnold, J. Feyen, and J. Berlamont. 2005. Modelling the hydrology of a catchment using a distributed and a semi-distributed model. Hydrologica Processes 19(3): 573-587.

Environmental Systems Research Institute (ESRI). 2002. ArcView 3.3. Redlands, CA.

Environmental Systems Research Institute (ESRI). 2005. ArcGIS 9.2. Redlands, CA.

Foley, J.A., R. DeFries, G.P. Asner, C. barford, G. Bonan, S.R. Carpenter, F.S. Chapin, M.T. Coe, G.C. Daily, H.K. gibbs, J.H. Helkowski, T. Holloway, E.A. Howard, C.J. Kucharik, C. Monfreda, J.A. Patz, I.C. Prentice, N. ramankutty, and P.K. Snyder. 2005. Global consequences of land use. Science 309(5734): 570-574.

Gassman, P.W., M.R. Reyes, C.H. Green and J.G. Arnold. 2007. The Soil and Water Assessment Tool: Historical development, applications, and future research directions. Transactions of the American society of Agricultural and Biological Engineers 50(4): 1211-1250.

Georgiyevsky, V., and I. Shiklomanov. 2003. Climate change and water resources. In: World Water Resources at the Beginning of the $21^{\text {st }}$ Century. $\mathrm{I}$. Shiklomanov and J. Rodda (eds.). UNESCO, Cambridge University Press, Cambridge, UK. 
Giorgi, F. 2005. Climate change prediction. Climatic Change 73(3): 239-265.

Gosin, A.K., S. Rao and D. Basuray. 2006. Climate change impact assessment on hydrology of Indian River basins. Current Science 90(3): 346-353.

Govender, M., and C.S. Everson. 2005. Modeling streamflow from two small South African experimental catchments using the SWAT model. Hydrological Processes 19(3): 683-692.

Graham, L.P., J. Andreasson, and B. Carlsson. 2007a, Assessing climate change impacts on hydrology from an ensemble of regional climate models, model scales and linking methods - A case study on the Lule River basin. Climatic Change 81(1): 293-307.

Graham, L.P., S. Hagemann, S. Jaun and M. Beniston. 2007b. On interpreting hydrological change from regional climate models. Climatic Change 81(1): $97-122$.

Graves, D., and H..Chang. 2007. Hydrologic impacts of climate change in the Upper Clackamas River basin, Oregon, USA. Climate Research 33(2): 143-157.

Grove, M., J. Harbor, B. Engle, and S. Muthukrishnan. 2001. Impacts of urbanization on surface hydrology, Little Eagle Creek, Indiana, and analysis of Ithia model sensitivity to data resolutions. Physical Geography 22(2): $135-156$.

Hall, M. 2003. Global warming and the demand for water. Journal of the Institution of Water and Environmental Management 17(3): 157-161.

Hawksworth, J.T. 2001. Middle Tualatin-Rock Creek watershed analysis. From the Tualatin River Watershed Council website. URL: lttp://www.trwc.org/tualatininfo/middle/middle.html, Downloaded: $11 / 26 / 2007$

Hejazi, M.I., and G.E. Moglen. 2007. Regression-based approach to low flow prediction in the Maryland Piedmont region under joint climate and land use change. Hydrological Process 21(14): 1793-1801.

Hingray, B., N. Mouhous, A. Mezghani, K. Bogner, B. Schaefli and A. Musy. 2007. Accounting for global-mean warming and scaling uncertainties in climate change impact studies: Application to a regulated lake system. Hydrology and Earth System Sciences 11(3): 1207-1226. 
Homer, C., C. Huang, L. Yang, B. Wilie, and M. Coan. 2004. Development of a 2001 national Land-Cover Database for the United States. Photogrammetric Engineering \& Reomte Sensing 70(7): 829-840.

Hulse, D., S. Gregory, and J. Baker (eds.). 2002. Willanette River Basin Planning Atlas: Trajectories of Environmental and Ecological Change. Oregon State University Press: Corvallis, Oregon.

Huntington, T. 2006. Evidence for intensification of the global water cycle: Review and synthesis. Journal of Hydrology 319: 83-95.

Intergovernmental Panel on Climate Change (IPCC). 2007. Summary for Policymakers. In: Climate Change 2007: The Physical Science Basis. Contribution of Working Group I to the Fourth Assessment Report of the Intergoverninental Panel on Climate Change. Solomon, S.D., Q.M. Manning, Z. Chen, M. Marquis; K.B. Averyt, M. Tignor and H.L. Miller (eds.). Cambridge University Press, Cambridge, United Kingdom and New York, NY, USA.

Jha, M., J.G. Arnold, P.W. Gassman, F. Giorgi, and R.R. Gu. 2006. Climate change sensitivity assessment on Upper Mississippi River Basin stream flows using SWAT. Jouinal of the American Water Resources Association 42(4): 997-1015.

Krysanova, V., F. Hattermann, and F. Wechsung. 2007. Implication of complexity and uncertainty for integrated modeling and impact assessment in river basins. Environmental Modelling \& Software 22(5): 701-709.

Lee, K.S., and E-S Chung. 2007. Hydrological effects of climate change, groundwater withdrawal, and land use in a small Korean watershed. Hydrological Processes 21(22): 3046-3056.

Legates, D.R., and G.J. McCabe Jr. 1999. Evaluating the use of "goodness-of-fit" measures in hydrologic and hydroclimatic model validation. Water Resources Research 35(1); 233-241.

Lin, Z. and D.E. Radcliffe. 2006. Automatic calibration and predictive uncertainty analysis of a semi-distributed watershed model. Vadose Zone Journal 5: 248-260.

Lyon, J.G. (ed). 2003. GIS for Water Resources and Watershed Management. Taylor \& Francis, London, UK and New York, NY, USA. 
Kalin, L., and M.M. Hantush. 2006. Effect of urbanization on sustainability of water resources in the Pocono Creek watershed. In Coastal Hydrology and Processes: Proceedings of the AIH $25^{\text {th }}$ Anniversary Meeting \& International Conference, "Challenges in Coastal Hydrology and Water Quality," eds. V.P. Singh and Y. Jun Xu. Water Resources Publications, LLC, Highlands Ranch, Colorado, USA.

Manguerra, H.B. and B.A. Engel. 1998. Hydrologic parameterization of watersheds for runoff prediction using SWAT. Journal of the American Water Resources Association 34(5): 1149-1162.

Martin, P.H., E.J. LeBoeuf, J.P. Dobbins, E.B. Daniel, M.D. Abkowitz. 2005. Interfacing G1S with water resource models: A state-of-the-art review. Journal of the American Water Resources Association 41(6): 1471-1487.

Means III, E., N. West, and R. Patrick. 2003. Population growth and climate change will pose tough challenges for water utilities. Journal of the American Water Works Association 97(8): 40-46.

Moglen, G.E. and R.E. Beighley. 2002. Spatially explicit hydrologic modeling of land use change. Journal of the American Water Resources Association 38(1): 241-253.

Moglen, G.E. and S. Kim. 2007. Limiting Imperviousness: Are threshold-based policies a good idea? Journal of the American Planning Association 73(2): 161-171.

Mote, P., E. Parson, A. Hamlet, W. Deeton, D. Lettenmaier, N. Mantua, E. Miles, D. Peterson, D. Peterson, R. Slaughter, and A. Snover. 2003. Preparing for climatic change: The water, salmon, and forests of the Pacific Northwest. Climatic Change 61(1-2): 45-88.

Mote, P.W., E.P Salathe, C. Peacock. 2005. Scenarios of Future Climate for the Pacifc Northwest. Unpublished Report, Climate Impacts Group, Center for Science in the Earth System, Joint Institute for the Study of the Atmosphere and Ocean, University of Washington, Seattle. URL: http://www.cses.washington.edu/. Downloaded: 01/23/2008.

Muleta, M.K., and J.W. Nicklow. 2005. Sensitivity and uncertainty analysis coupled with automatic calibration for a distributed watershed model. Journal of Hydrology 306(1-4): 127-145. 
Muleta, M.K., J.W. Nicklow and E.G. Bekele. 2007. Sensitivity of a distributed watershed simulation model to spatial scale. Journal of Hydrologic Engineering 12(2): 163-172.

National Hydrography Dataset Plus (NHDPlus). 2007. NHDPlus flowlines. From Horizon Systems Corporation, NHDPlus website. URL: http://www.horizon systems.com/nhdplus/index.php. Downloaded: 05/15/2007.

National Resource Conservation Service (NRCS). 2001. STATSGO Soils Dataset, Oregon. From Soil and Water Assessment Tool (SWAT), AVSWAT Soil Database Downloads website. URL: http://www.brc.tamus.edu/swat/doc_databases-soils.html. Downloaded: 04/05/2007.

Neitsch, S.L., J.G. Arnold, J.R. Kiniry, R. Srinivasan, and J.R. Williams. 2002. Soil and Water Assessment Tool: User's Manual, version 2000. Grassland and Water Research Laboratory \& Blackland Research Center, Tenple, Texas, USA.

Neitsch, S.L., J.G. Arnold, J.R. Kiniry, R. Srinivasan, and J.R. Williams. 2004. Soil and Water Assessment Tool: Input/Output File Documentation, Version 2005. Grassland and Water Research Laboratory \& Blackland Research Center, Temple, Texas, USA.

Neitsch, S.L., J.G. Arnold, J.R. Kiniry, and J.R. Williams. 2005. Soil and Water Assessment Tool: Theoretical Documentation, version 2005. Grassland and Water Research Laboratory \& Blackland Research Center, Temple, Texas, USA.

Nicholls, N., and L. Alexander. 2007. Has the climate become more variable or extreme? Progress 1992-2006. Progress in Physical geography 31(1): 77-87.

Niehoff, D., U. Fritsch, and A. Bronstert. 2002. Land-use impacts on storm-runoff generation: Scenarios of land-use change and simulation of hydrological response in a meso-scale catchment in SW-Germany. Journal of Hydrology 267(1): 80-93.

Olivera; F. and B.B. DeFee. 2007. Urbanization and its effect on runoff in the Whiteoak Bayou watershed, Texas. Journal of the American Water Resources Association 43(1): 170-182. 
Oregon Blue Book. 2007. Oregon City and County Populations, 70-06. From OregonBlue Book website. URL:

http://bluebook.state.or.us/local/populations/populations.htm. Downloaded: $11 / 27 / 2007$.

Oregon Climate Service (OCS). 2007. Station Climate Data, Zone 2. From Oregon Climate Service website. URL: http://www.ocs.orst.edu/index.html. Downloaded: $05 / 26 / 2007$.

Oregon Geospatial Data Clearinghouse (OGDC). (2005). Oregon Geospatial Enterprise Office. From the Oregon.gov website. URL: http://www.oregon.gov/DAS/EISPD/GEO/alphalist.shtml. Downloaded: 05/15/2007.

Oregon Water Resources Department (OWRD). 2007. Surface Water, Historic Stream Flow. From Oregon Water Resources Department (OWRD), Washington County, District-18, Watermaster website. URL: http://www.co.washington.or.us/deptmts/wtr_mstr/surfacewater.html. Downloaded: 05/03/2007.

Palmer, R., and M. Hahn. 2002. The impacts of climate change on Portland's water supply: An investigation of potential hydrologic and managernent impacts on the Bull Run System. Department of Civil and Environmental Engineering, University of Washington, Seattle, WA. Report prepared for Portland Water Bureau, Portland, Oregon.

Palmer, R., E. Clancy, N. VanRheenen, and M. Wiley. 2004. The impacts of climatechange on the Tualatin River basin water supply. Department of Civil and Environmental Engineering, University of Washington, Seattle, Washington. Report prepared for Clean Water Services, Hillsboro, Oregon.

Payne, J.T., A.W. Wood, A.F. Hamlet, R.N. Palmer, and D.P. Lettenmaier. 2004. Mitigating the effects of climate change on the water resources of the Columbia River Basin. Climatic Change 62(1-3): 233-256.

Pinter, N., R. van der Ploeg, P. Schweigert, and G. Hoefer. 2006. Flood magnification on the River Rhine. Hydrological Processes 20(1): 147-164.

Pacific Northwest Ecosystem Research Consortium (PNWERC). 2002. Future Scenarios. From Pacific Northwest Ecosystem Research Consortium (PNWERC), The Datasets website. URL: http://www.fsl.orst.edu/pnwerc/wrb/access.html. Downloaded: 08/23/2007. 
Reynard, N.S., C. Prudhomme, and S.M. Crooks. 2001. The flood characteristics of large U.K. rivers: Potential effects of changing climate and land use. Climatic Change 48(2-3): 343-359.

Salathe Jr., E.P. 2005. Downscaling simulations of future global climate with application to hydrologic modeling. International Journal of Climatology 25(4): 419-436.

Salathe Jr., E.P. 2007. ECHAM5 Daily Downscaled Data. Center for Science in the Earth System (CSES), University of Washington. Personal Correspondence, 12/18/2007.

Salathe Jr., E.P., P.W. Mote, and M.W. Wiley. 2007. Review of scenario selection and downscaling methods for the assessment of climate change impacts on hydrology in the United States Pacific Northwest. International Journal of Climatology (in press).

Samaniego, L., and A. Bardossy. 2006. Simulation of the impacts of land/cover and climatic change on the runoff characteristics at the mesoscale. Ecological Modeling 196(1-2): 45-61.

Santhi, C., J.G. Arnold, J.R. Williams, W.A. Dugas, R. Srinivasan, and L.M. Hauck. 2001. Validation of the SWAT model on a large river basin with point and non-point sources. Joumal of the American Water Resources Association 37(5): 1169-1188.

Schueler, T. 1994. The importance of imperviousness. Watershed Protection Techniques 1(3): 100-111.

Singh, V.P. and D.K. Frevert (eds.). 2006. Watershed Models. CRC Press, Boca Raton, FL, USA.

Snover, A.K., A.F. Hamlet, and D.P. Lettenmaier. 2003. Climate-change scenarios for water planning studies: Pilot applications in the Pacific Northwest. Bulletin of the American Meteorological Society 84(11): 1513-1518.

Soil and Water Assessment Tool (SWAT). 2007. Baseflow Filter Program. From Official SWAT website. URL: http://www.brc.tamus.edu/swat/soft baseflow.html. Downloaded: $10 / 22 / 2007$. 
Spak, S., T. Holloway, B. Lynn and R. Goldberg. 2007. A comparison of statistical and dynamical downscaling for surface temperature in North America. Journal of Geophysical Research 112(D08101): 1-10.

Stone, M.C., R.H. Hotchkiss, C.M. Hubbard, T.A. Fontaine, L.O. Mearns, and J.G. Arnold. 2001. Impacts of climate change on Missouri river basin water yield. Journal of the American Water Resources Association 37(5): 1119-1129.

Sullivan, A., J. Ternan, and A. Williams. 2004. Land use change and hydrological response in the Camel catchment, Cornwall. Applied Geography 24(2): 119-137.

Taha, H. 1997. Urban climates and heat islands: albedo, evapotranspiration, and anthropogenic heat. Energy and Buildings 25(2): 99-103.

Tang, Z., B.A. Engel, B.C. Pijanowski, and K.J. Lim. 2005. Forecasting land use change and its environmental impact at a watershed scale. Journal of EnvironmentalManagement 76(2): 35-45.

Thodsen, H. 2007. The influence of climate change on stream flow in Danish rivers. Journal of Hydrology 333(3-4): 226-238.

Thomson, A.M., R.A. Brown, N.J. Rosenberg, R. Srinivasan and R.C. Izaurralde. 2005. Climate change impacts for the conterminous USA: An integrated approach, Part 4: Water resources. Climatic Change 69(1): 67-88.

Trenberth, K.E., A. Dai, R.M. Rasmussen, and D.B. Parsons. 2003. The changing character of precipitation. Bulletin of the American Meteorological Society 84(9): 1205-1217.

Tollan, A. 2002. Land-use change and floods: What do we need most, research or management? Water Science and Technology 45(8): 183-190.

U.S. Geological Survey (USGS). 2004. National Elevation Dataset (NED) 1/3 Arc Second ( 10m resolution). From U.S. Geological Survey, Seamless Data National Elevation Dataset webpage. URL:

http://seamless.usgs.gov/Website/Seamless/products/3arc.asp. Downloaded: $04 / 05 / 2007$.

U.S. Geological Survey (USGS). 1992. National Land Cover Dataset, 1992. From U.S. Geological Survey, Land Cover Institute (LCI) website http://landcover.usgs.gov/natllandcover.php. Downloaded: 10/05/2007. 
U.S. Geological Survey (USGS). 2001. National Land Cover Dataset, 2001. From U.S. Geological Survey, Land Cover Institute (LCI) website http://landcover.usgs.gov/natllandcover.php. Downloaded: 10/05/2007.

VanGriensven, A. (Draft) Sensitivity, auto-calibration and model evaluation in SWAT2005. URL: www.cropsoil.uga.edu/soilphysics/medial SWAT2005_manual_sens_cal_unc4.doc. Downloaded: 10/14/2007.

VanRheenen, N.T., R.N. Palmer, and M.A. Hahn. 2003. Evaluating potential climatechange impacts on water resource systems operations: Case studies of Portland, Oregon and Central Valley, California. Water Resources Update 124: 35-50.

VanRheenen, N.T., A.W. Wood, R.N. Palmer, and D.P. Lettenmaier. 2004. Potential implications of PCM climate change scenarios for Sacramento San Joaquin River basin hydrology and water resources. Climatic Change 62(1-3): 257-281.

Varanou, E., E. Gkouvatsou, E. Baltas, and M. Mimikou. 2002. Quantity and quality integrated catclment modeling under climate change with use of Soil and WaterAssessment Tool model. Journal of Hydrologic Engineering $7(3): 228-244$

Varis, O., T. Kajander, and R. Lemmela. 2004. Climate and water: From climate models to water resources management and vice versa. Climatic Change 66(3): 321-344.

Vicuna, S., and J.A. Dracup. 2007. The evolution of climate change impact studies on hydrology and water resources in California. Climatic Change 82(3-4): $327-350$.

Vicuna, S., E.P. Maurer, B. Joyce, J.A. Dracup, and D. Purkey. 2007. The sensitivity of California water resources to climate change scenarios. Journal of the American Water Resources Association 43(2): 482-498.

Vorosmarty, C.J., P. Green, J. Salisbury, and R. Lammers. 2000. Global water resources: Vulnerability from climate change and population growth. Science 289(5477): 284-288.

Watts, G. 1997. Hydrological Modeling in Practice, In: Contemporary Hydrology: Towards Holistic Environmental Science. Wilby, R.L (ed.). John Wiley \& Sons, Ltd., New York, NY, USA. 
Weng, Q. 2001. Modeling urban growth effects on surface runoff with the integration of remote sensing and GIS. Environmental Management 28(6): 737-748.

Wheater, H.S. 2006. Flood hazard and management: A UK perspective. Philosophical Transactions of the Royal Society, A 364(1845): 2135-2145.

White, M.D. and K.A. Greer. 2006. The effects of watershed urbanization on the stream hydrology and riparian vegetation of Los Penasquitos Creek, California. Landscape and Urban Planning 74(2): 125-138.

Wilby, R.L., P.G. Whitehead, A.J. Wade, D. Butterfield, R.J. Davis, and G. Watts. 2006. Integrated modeling of climate change impacts on water resources and quality in a lowland catchment: River Kennet, UK. Journal of Hydrology 330(1-2): 204-220.

Wood, A.W., L.R. Leung, V. Sridhar, and D.P. Lettenmaier. 2004. Hydrologic implications of dynamical and statistical approaches to downscaling climate model outputs. Climatic Change 62(1-3): 189-216.

$\mathrm{Xu}, \mathrm{C}$. 1999. From GCMs to river flow: A review of downscaling methods and hydrologic modeling approaches. Progress in Physical Geography 23(2): $229-249$.

Zhang, X., R. Srinivasan, and F. Hao. 2007. Predicting hydrologic response to climatechange in the Luohe River basin using the SWAT model. Transactions of the American Society of Agricultural and biological engineers (ASABE) 50(3): 901-910. 


\section{APPENDIX}

Table A.1: PNW-ERC land cover projection land cover types and the corresponding SWAT land cover categories.

\begin{tabular}{|c|c|c|c|}
\hline Class Code & Class Description & SWVAT Code & SWAT Definition \\
\hline 1 & Residential, 0-4 DU/ac & URLD & Residential-Low Density \\
\hline 2 & Residential, 4*9 DU/ac & URMD & Residential-Medium Density \\
\hline 3 & Residential, 9-16 DU/ac & URMD & Residential-Medium Density \\
\hline 4 & Residential, $>16$ DU/ac & URHD & Residential-High Density \\
\hline 6 & Commercial & URHD & Residential-High Density \\
\hline 7 & Commercial/Industrial & URHD & Residential-High Density \\
\hline 8 & Industrial & URHD & Residential-Higll Density \\
\hline 10 & Residential/Industrial & URHD & Residential-High Density \\
\hline 11 & Urban non-vegetated unknown & URMD & Residential-Medium Density \\
\hline 16 & Rurual structures & URLD & Residential-Low Density \\
\hline 18 & Railroad & TRAN & Transportation \\
\hline 20 & Secondary roads & TRAN & Transportation \\
\hline 21 & Light duty roads & TRAN & Transportation \\
\hline 24 & Rural non-vegetated unknown & BERM & Bermudagrass \\
\hline 33 & Penmanent Lentic? Water & WATR & Water \\
\hline 39 & Topographic shadow & BERM & Bermudagrass \\
\hline 49 & Urban tree overstory & URLD & Residential-Low Density \\
\hline 51 & Urban forest open & URLD & Residential-Low Density \\
\hline 52 & Urban forest semi-closed nixed & URLD & Residential-Low Density \\
\hline 53 & Forest closed hardwood & FRSD & Forest-Deciduous \\
\hline 54 & Forest closed mixed & FRST & Forest-Mixed \\
\hline 55 & Upland forest semi-closed conifer & FRSE & Forest-Evergreen \\
\hline 56 & Conifers $0-20$ yrs & FRSE & Forest-Evergreen \\
\hline 57 & Forest closed conifer $21.40 \mathrm{yrs}$ & FRSE & Forest-Evergreen \\
\hline 58 & Forest closed conifer $41-60$ yrs & FRSE & Forest-Evergreen \\
\hline 59 & Forest closed conifer $61-80$ yrs & FRSE & Forest-Evergreen \\
\hline 60 & Forest closed conifer $81-200$ yrs & FRSE & Forest-Evergreen \\
\hline 61 & Forest closed conifer $>200$ yrs & FRSE & Forest-Evergreen \\
\hline 62 & Upland forest semi-closed hardwood & FRSD & Forest-Deciduous \\
\hline 66 & Hybrid Poplar & FRSD & Forest-Deciduous \\
\hline 67 & Grass sced rotation & HAY & Hay \\
\hline 68 & Irrigated annual'rotation & AGRL & Agricultural Land-Generic \\
\hline 71 & Grains & HAY & Hay \\
\hline 72 & Nursery & AGRL & Agricultural Land-Generic \\
\hline 73 & Berries \& vineyards & AGRL & Agricuitural Land-Gencric \\
\hline 74 & Double cropping & AGRL & Agricultural Land-Gencric \\
\hline 76 & Mint & AGRL & Agricultural Land-Generic \\
\hline 78 & Sugar beet secd & $\mathrm{HAY}$ & Hay \\
\hline
\end{tabular}




\begin{tabular}{|c|l|l|l|}
\hline Class Code & Class Description & SWAT Code & SWAT Delinition \\
\hline 79 & Row crop & AGRL & Agricultural Land-Generic \\
\hline 80 & Grass seed rotation & HAY & Hay \\
\hline 82 & Field crop & AGRL & Agricultural Land-Generic \\
\hline 83 & Haylield & HAY & Hay \\
\hline 84 & Late field crops & AGRL & Agricultural Land-Generic \\
\hline 85 & Pasture & HAY & Hay \\
\hline 86 & Natural grassland & SWGR & Slender Wheat Grass \\
\hline 87 & Natural shrib & SWRN & Range-SW United States \\
\hline 88 & Bare/lallow & RNGE & Range Grasses \\
\hline 89 & Flooded/marsh & WETF & Wetlands-forested \\
\hline 90 & Irrigated perennial & AGRL & Agricultural Land-Generic \\
\hline 91 & Turfgrass & HAY & Hay \\
\hline 92 & Orchard & AGRL & Agricultural Land-Generic \\
\hline 93 & Christmas Tress & FRSE & Forest-Evergreen \\
\hline 95 & Conifer woodlot & FRSE & Forest-Evergreen \\
\hline 101 & Wet shrub & WETN & Wetlands-Nonforested \\
\hline
\end{tabular}


Table A.2: The USGS 2001 land cover codes and the corresponding AVSWAT-X categories chosen to reclassify the land cover layer.

\begin{tabular}{|l|l|l|l|}
\hline $\begin{array}{l}\text { USGS } \\
\text { Value }\end{array}$ & \multicolumn{1}{|c|}{ Land Use Definition } & $\begin{array}{l}\text { SWAT } \\
\text { Value }\end{array}$ & \multicolumn{1}{|c|}{ Land Use Definition } \\
\hline 11 & Open Water & WATR & Water \\
\hline 21 & Developed, Open Space & BERM & Bermuda Grass \\
\hline 22 & Developed, Low Intensity & URLD & Residential-Low Density \\
\hline 23 & Developed, Medium Intensity & URMD & Residential-Medium Density \\
\hline 24 & Developed, High Intensity & URHD & Residential-High Density \\
\hline 31 & Barren Land (Rock/Sand/Clay) & RNGE & Range Grasses \\
\hline 41 & Deciduous Forest & FRSD & Forest-Deciduous \\
\hline 42 & Evergreen Forest & FRSE & Forest-Evergreen \\
\hline 43 & Mixed Forest & FRST & Forest-Mixed \\
\hline 52 & Shrub/Scrub & SWRN & Range-SW United States \\
\hline 71 & Grassland/Herbaceous & SWGR & Slender Wheat Grass \\
\hline 81 & Pasture/Hay & HAY & Hay \\
\hline 82 & Cultivated Crops & AGRL & Agricultural Land-Generic \\
\hline 90 & Woody Wetlands & WETF & Wetlands-Forested \\
\hline 95 & Emergent Herbaceous Wetlnds & WETN & Wetlands-Nonforested \\
\hline
\end{tabular}


Table A.3: Shows the HRU distribution within the Rock Creek watershed.

MULTIPLE HRUs LandUse/Soil OPTION THRESHOLDS : $10 / 5$ [\%]

Number of HRUs: 161

Number of Subbasins: 33

WATERSHED:

LANDUSE:

Residential-High Density-->URHD

Water-->WATR

Wetlands-Forested-->WETF

Bermudagrass-->BERM

Forest-Deciduous-->FRSD

Forest-Evergreen-->FRSE

Slender Wheatgrass-->SWGR

Forest-Mixed-->FRST

Hay-->HAY

Residential-Low Density-->URLD

Agricultural Land-Generic-->AGRL

Residential-Medium Density-->URMD
Area [ha]

19034.4999

740.2541

2.4319

11.6456

665.9264

209.1927

878.1045

135.5986

1400.3957

2689.8271

6637.0128

365.1048

5299.0056
Area [acres] 47035.2010

$\begin{array}{ll}1829.2050 & 3.89 \\ 6.0093 & 0.01 \\ 28.7768 & 0.06 \\ 1645.5375 & 3.50 \\ 516.9257 & 1.10 \\ 2169.8402 & 4.61 \\ 335.0709 & 0.71 \\ 3460.4478 & 7.36 \\ 6646.6972 & 14.13 \\ 16400.3904 & 34.87 \\ 902.1922 & 1.92 \\ 13094.1079 & 27.84 \\ & \\ 788.6215 & 1.68 \\ 20714.3954 & 44.04 \\ 4043.4502 & 8.60 \\ 48.6518 & 0.10 \\ 21440.0821 & 45.58\end{array}$

SOIL:

$\begin{array}{llll}\text { OR081 } & 319.1443 & 788.6215 & 1.68 \\ \text { OR082 } & 8382.8313 & 20714.3954 & 44.04 \\ \text { OR090 } & 1636.3288 & 4043.4502 & 8.60 \\ \text { OR096 } & 19.6887 & 48.6518 & 0.10 \\ \text { OR098 } & 8676.5068 & 21440.0821 & 45.58\end{array}$


Table A.4: This table shows the 27 different parameters considered in the output of the automated sensitivity analysis tool, a brief description of each one, and the relative ranking (Source: Neitsch et al. 2004).

\begin{tabular}{|c|c|c|c|c|}
\hline Parameter & Description & Unit & Rank & Calibrated \\
\hline $\mathrm{CN} 2$ & $\begin{array}{l}\text { SCS runoff curve number, moisture } \\
\text { condition II }\end{array}$ & Range & 1 & $\mathrm{X}$ \\
\hline CH_K2 & $\begin{array}{l}\text { Effective hydraulic conductivity in main } \\
\text { channel alluvium }\end{array}$ & $\mathrm{mm} / \mathrm{hr}$ & 2 & $X$ \\
\hline Surlag & Surface runoff lag coefficient & N/A & 3 & \\
\hline ALPHA BF & Base flow alpha factor & Days & 4 & $\mathrm{X}$ \\
\hline Sol_z & Depth from soil surface to bottom of layer & & 5 & $\mathrm{X}$ \\
\hline SOL_AWC & Available water capacity of the soil layer & $\begin{array}{l}\mathrm{mm} \mathrm{H}_{2} \mathrm{O} \\
/ \mathrm{mm} \text { soil }\end{array}$ & 6 & $\mathrm{X}$ \\
\hline TIMP & Snow pack temperature lag factor & N/A & 7 & \\
\hline SFTMP & Snow melt base temperature & ${ }^{\circ} \mathrm{C}$ & 8 & \\
\hline SMFMX & Melt factor for snow on June 21 & $\mathrm{~N} / \mathrm{A}$ & 9 & \\
\hline SMTMP & Snowfall temperature & ${ }^{\circ} \mathrm{C}$ & 10 & \\
\hline $\mathrm{ESCO}$ & Soil evaporation compensation factor & N/A & 11 & $\bar{X}$ \\
\hline Ch_n & $\begin{array}{l}\text { Manning's " } n \text { " value for tributary } \\
\text { channets }\end{array}$ & $\mathrm{N} / \mathrm{A}$ & 12 & \\
\hline Sol k & Saturated hydraulic conductivity & $\mathrm{mm} / \mathrm{hr}$ & 13 & \\
\hline Canmx & Maximum canopy storage & $\mathrm{mm} \mathrm{H} \mathrm{H}_{2} \mathrm{O}$ & 14 & \\
\hline SLOPE & Slope & $\mathrm{m} / \mathrm{m}$ & 15 & \\
\hline SLSUBBSN & Average slope length & $m$ & 16 & \\
\hline SMFMN & Melt factor for snow on December 21 & N/A & 17 & \\
\hline Sol alb & Moist soil albedo & $\mathrm{N} / \mathrm{A}$ & 18 & \\
\hline Epco & Plant uptake compensation factor & N/A & 19 & \\
\hline BIOMIX & Biological mixing efficiency & N/A & 20 & \\
\hline GWQMN & $\begin{array}{l}\text { Threshold depth of groundwater required } \\
\text { for return flow to occur }\end{array}$ & $\mathrm{mm} \mathrm{H}_{2} \mathrm{O}$ & 28 & \\
\hline GW_REVAP & $\begin{array}{l}\text { Groundwater "revap" coefficient, moves } \\
\text { water from shallow aquifer to root zone }\end{array}$ & N/A & 28 & \\
\hline REVAPMN & $\begin{array}{l}\text { Shallow water depth threshold in shallow } \\
\text { aquifer }\end{array}$ & $\mathrm{mm} \mathrm{H}_{2} \mathrm{O}$ & 28 & \\
\hline TLAPS & Temperature lapse rate & ${ }^{\circ} \mathrm{C} / \mathrm{km}$ & 28 & \\
\hline GW DELAY & Delay the groundwater recharge & Days & 28 & \\
\hline Rchrg dp & Deep aquifer percolation fraction & N/A & 28 & \\
\hline Blai & Maximum potential leaf area index & $\mathrm{N} / \mathrm{A}$ & 28 & \\
\hline
\end{tabular}

